\title{
ALBERONI Y EL GOBIERNO DE LA MONARQUÍA ESPAÑOLA
}

\author{
Isabel MARTÍNEZ NAVAS \\ PROFESORA TITUlAR DE Historia DEL DERECHO \\ UNIVERSIDAD DE LA RIOJA
}

\begin{abstract}
SUMARIO: Introducción. I. Semblanza personal y política del Cardenal Alberoni. I.I. Primeros pasos en la Corte. I.r.I. A la sombra de Vendôme. I.r.2. Agente extraordinario del Duque de Parma. I.I.3. Primera misión oficial en la Corte española. I.2. Alberoni, favorito de los Reyes. I.2.I. Consejero de la Reina. I.2.2. Privado y Cardenal. I.3. Cese, persecución y rehabilitación pública. I.3.I. El cese y los documentos en poder de Alberoni. I.3.2. Arresto y procesamiento de Alberoni. II. Alberoni y el gobierno de la Monarquía española. II.I. Reformismo y contrarreformismo. II.I.I. Las reformas Ursinos-Orry. II.I.2. El Ministerio del Cardenal Giudice y la intervención de Alberoni en los negocios públicos. II.2. El bienio Alberoni. II.2.I. La reforma de los Consejos y de la "vía reservada". II.2.2. Los poderes de Alberoni. La praxis de gobierno.
\end{abstract}

RESUMEN: Entre I7I7 y I7ı9 Felipe V contó con un "Ministro principal”, Giulio Alberoni. La difusa naturaleza del poder ejercido por este Ministro, hace necesario el establecimiento de contornos precisos -cronológicos, institucionales y, en alguna medida también, materiales- a su intervención en el gobierno de la Monarquía española.

PALABRAS CLAVE: Alberoni. Privados. Validos y Primeros Ministros. Reformismo. Consejos. Vía reservada.

KEYWORDS: Alberoni. Private. Prime ministers.. Advices. Reserved route.

\section{Introducción}

Las páginas que siguen tienen por objeto el estudio de la actividad pública desarrollada por uno de los Ministros extranjeros de Felipe V, el Cardenal Giulio Alberoni, quien, como tantos otros favoritos resultó repentinamente apartado de su posición de poder y sometido a una pertinaz persecución que, a pesar de su resultado finalmente favorable a Alberoni, lo alejó definitivamente del escenario de la vida política europea en la que había llegado a tener un lugar destacado por espacio de algo más de dos años.

Alberoni es, probablemente, uno de los protagonistas del escenario político de las primeras décadas del siglo XVIII que ha concitado más juicios encontrados acerca de su actividad pública. Ministro esforzado y generoso para unos, interesado en la única defensa de su medro particular, para la mayoría, estuvo desde el comienzo en el punto de mira de la Cancillería francesa, que procuró, sin éxito, su caída, en varias ocasiones. Sus primeros biógrafos ofrecen una imagen, sin duda, distorsionada, mediatizados por el ambiente que rodeó al proceso seguido a Alberoni tras su salida de España en diciembre de I7I9. La sucesiva aparición de diversas publicaciones debidas al entorno del Cardenal que trataban de hacer frente a los cargos acumulados contra Alberoni, trató de contrarrestarse con la publicación de otros tantos escritos condenatorios. Después, la abundante producción 
historiográfica en torno a la figura del Ministro de Felipe $\mathrm{V}$ - en su mayor parte italianaha incidido asimismo en el afán de culpabilizar a Alberoni, o más frecuentemente, en destacar sus abundantes méritos, haciéndolo aparecer como una víctima de la compleja política europea del momento. La relevancia del conflicto en el que de nuevo se embarcaron las potencias europeas en I7I 8 y en el que el Cardenal Alberoni, con más o menos entusiasmo, jugó un papel destacado, ha ensombrecido sus otras intervenciones en el gobierno de la Monarquía española. Después, la sonora caída del todopoderoso Ministro como más adelante las de Ensenada o Aranda - ha contribuido definitivamente a eclipsar en buena medida sus logros. La persecución a la que se le sometió y su enconada defensa, la fortuna que, una vez más, salió a su encuentro en forma de relevo al frente de la Santa Sede, la posterior rehabilitación y sus últimos proyectos en su tierra italiana, constituyen una tercera parte en la vida del Cardenal Alberoni que carece de interés para la historia política europea —y aún para la española - y de la que se ha ocupado casi exclusivamente la historiografía italiana.

Lo que me propongo en las siguientes páginas es una aproximación a la naturaleza del poder ejercido por Giulio Alberoni. Tratar de establecer contornos precisos a la intervención de este Ministro de origen italiano en el gobierno de la Monarquía española. Cronológicos, en primer término, describiendo las diferentes etapas por la que fue atravesando su brillante posición en el entorno de los Reyes. Institucionales, incidiendo en la posición que ocupa Alberoni en la estructura del gobierno central de la Monarquía española. Y, también, materiales, reordenando algunas de las noticias relativas a la actuación política del Ministro parmesano.

\section{Semblanza personal y política del Cardenal Alberoni}

En la primera parte del estudio presento el itinerario seguido por Alberoni desde su debut en la Corte española, hasta su traumática expulsión diez años más tarde. Trato de establecer aquí los límites cronológicos de las diferentes etapas que jalonan la vida pública de Alberoni. He marcado así el comienzo de su actividad política en España, su papel de representante de una Corte extranjera, que nunca abandonó, su carácter de favorito de los Reyes y su ulterior condición de Ministro principal de Felipe V. Me detengo asimismo en unas breves pinceladas relativas a su trayectoria vital con anterioridad a su llegada a España y al término de su Privanza. Para todo ello me sirvo, fundamentalmente, de las numerosas biografías de Alberoni publicadas desde el final de la segunda década del siglo XVIII y de un buen número de manuscritos atentos a la trayectoria vital del Cardenal Alberoni conservados en la Biblioteca Nacional de Madrid, la British Library y la Biblioteca del Palacio Real de Madrid. Sobre su infancia y juventud, me interesa únicamente destacar su humilde origen y la potenciación de una atractiva personalidad que le permitió obtener el respaldo preciso para iniciar, aunque tardíamente, una sólida formación.

Giulio Alberoni nació en el año i664 en un barrio pobre de la ciudad de Piacenzar. Primero de los seis hijos del matrimonio formado por Giovanni María Alberoni y Laura Ferrari, pronto tuvo que emplearse como sirviente en una de las parroquias de la ciudad, contribuyendo al sostenimiento de sus hermanos tras la muerte de su padre. A los doce años Alberoni carecía de formación, pero un nuevo empleo como campanero en la catedral de Piacenza le permitió ir ganándose el patrocinio de los canónigos, al tiempo que se adentraba en los rudimentos de la lectura, lo que le facilitó después incorporarse a una escuela y finalmente ordenarse sacerdote en $\mathrm{I}_{69 \mathrm{O}^{2}}$. Gracias a sus buenas maneras llamó la

I Sobre la fecha exacta de su nacimiento parece aceptarse el 2I de mayo -en que fue bautizado en la parroquia de S. Nazario y S. Celso-. Excepcionalmente, se ha apuntado también el 30 de marzo de I664.

2 Alberoni tuvo que comenzar a sostener a su familia en $\mathrm{i} 674$, trabajando inicialmente como campanero de los monjes de Santa María de Valverde y más adelante como auxiliar en la sacristía de S. Nazario. Después, y hasta los diecisiete años, se pierde su rastro, recobrándose en I680, en que lo encontramos estudiando filosofía 
atención del Obispo Barni, entrando a su servicio como preceptor de su sobrino, merced a lo cual pudo viajar a Roma con aquél, conociendo de primera mano los vericuetos de la política de aquella Corte e instruyéndose —al tiempo que lo hacía el joven Barni- en diversas materias como la literatura religiosa y profana y la lengua francesa. Sus conocimientos de esta última le proporcionaron después su mejor oportunidad, toda vez que, habiéndose establecido el Duque de Vendôme como comandante general de las tropas asentadas en Italia, el Duque de Parma resolvió comisionar como enviado al cuartel general de Vendôme al Obispo Roncoveri, quien se sirvió de Alberoni como intérprete. Pronto Alberoni sustituyó a Roncoveri en la misión cerca de Vendôme, al que acompañó después cuando éste regresó a Francia. De París pasó con el Duque a Flandes y, más adelante, a España, donde permaneció tras la muerte del Duque en I7I2, hasta su precipitada salida en diciembre de I7I9. Dos años antes había recibido el Capelo cardenalicio de manos de Clemente XI, quien poco después se habría negado a concederle la bula del arzobispado de Sevilla, lo que dio lugar a un lamentable incidente diplomático, a la retirada del nuncio apostólico de Madrid y a la salida asimismo de los eclesiásticos españoles que se hallaban en Roma.

En sus años de Ministro poderoso, Alberoni había ido abriendo otros frentes en el complejo escenario político internacional resultante de Utrecht, que lo colocaron en el punto de mira de las potencias europeas y provocaron la pérdida de confianza por parte de los Reyes y severas acusaciones desde Roma. El 5 de diciembre de I7I9 resultó fulminantemente apartado de su magnífica posición. Conmocionado, trató inútilmente de ponerse en contacto con los Reyes. Poco después inició los preparativos para su partida, viéndose aún sometido durante el viaje a la humillación de tener que exponer su equipaje y los documentos que llevaba consigo. Con todo, su persecución no había hecho sino comenzar. Se intentó primero su arresto en Génova, pero el Senado de aquella República le declaró libre de cargos ${ }^{3}$. Obligado a abandonar la República genovesa, permaneció durante algún tiempo en paradero desconocido — probablemente refugiado en casa de algunos amigos en Lugano - siendo entre tanto sometido a nuevas investigaciones en España y en Roma ${ }^{4}$. Finalmente exculpado y confirmado en el cardenalato, Alberoni vivió con cierta tranquilidad hasta su muerte en 1752.

Para sus colaboradores, Alberoni fue un trabajador incansable, innovador y temerario en sus arriesgadas empresas, como decía Riperdá, extremadamente hábil en el manejo de los negocios, según afirmaba Patiño, para quien Alberoni era capaz de hacer simplemente difícil lo que aparecía como imposibles. «Bajo, ligeramente corpulento, de ojos penetrantes y una voz suave, era un hombre muy cultivado». La facilidad para entablar

en el colegio jesuítico de San Pietro. Al respecto, S. HARCOURT-SMITH, Una conspiración en la Corte de Felipe V, trad. de F. Gil, Madrid, I947, pp. 28-29.

3 Según refiere el Marqués de SAN FELIPE, Comentarios de la guerra de España e Historia de su Felipe V, el Animoso, Madrid, BAE, I957, págs. 3I9-323, fue Felipe V quien, no queriendo proceder directamente contra Alberoni, logró, con el apoyo del Duque de Parma, que el pontífice resolviese la apertura del proceso contra el cardenal.

4 En España se le seguía causa «por manejos indebidos en los tesoros reales», en tanto para la causa romana se remitieron los informes resultantes de la comisión pontificia ejercida por el Obispo de Barcelona e inquisidor general, Diego de Astorga y Céspedes. En el Archivo Histórico Nacional [en adelante, AHN], Estado, 2884/3, doc. 6, puede verse el Papel informativo para el Papa sobre las operaciones y costumbres del Cardenal Alberony, así como diversos documentos relacionados con la investigación llevada a cabo por el inquisidor general. Sobre el desarrollo y desenlace de ambos procesos, ver el reciente trabajo de C. MAQUEDA, Alberoni: entorno jurídico de un poder singular, Madrid, 2009.

5 P. MASSUET, Historia del Duque de Riperdá, Primer Ministro de España, en el nado del señor Felipe Quinto: dedicada al Emmo. Sr. Cardenal de Molina, presidente que fue de Castilla, dividida en dos partes, Madrid, I790, ff. 55-59; G. DREI, Giulio Alberoni, Bologna, I932, pág. 80; y J. LYNCH, El Siglo XVIII, Barcelona, I99I, pág. 73 .

6 H. KAMEN, Felipe V, el que reinó dos veces, Madrid, 2000, pág. I38. La descripción encaja con la Storia del Cardinale Alberoni, cit., recogida por G. DREI, Giulio Alberoni, cit., págs. 72-74. 
conversación y la libertad con que hablaba, resultaban atractivas para sus interlocutores. Desde su juventud, aun careciendo absolutamente de formación, cautivó con sus gratas maneras a todos aquellos de los que pudo obtener el respaldo y la protección que le permitieron progresar extraordinariamente. Enormemente ambicioso, «su elevado espíritu le llevaba a cosas grandes», de suerte que una vez fue tentado con la posibilidad de alcanzar el cardenalato - a decir del Marqués de SAN FELIPE- « pa Alberoni no servía más que a sí mismo», acercándose a cuantos podían favorecer su elevación y desplegando sus dotes innatas para la política ${ }^{7}$.

Arteras y disimuladas fueron sus actuaciones en la Corte madrileña hasta lograr persuadir a la todopoderosa Princesa de los Ursinos de las bondades del proyecto que patrocinaba. La Ursinos, a la que cultivó largo tiempo tratando de obtener su confianza, no llegó probablemente a convencerse de la sinceridad y falta de doblez de Alberoni. Si lo estuvo, sin embargo la Reina María Luisa de Saboya, que consideró a Alberoni como un servidor fiel y honrado. Antes que con esta Reina, Alberoni había conseguido introducirse también en la Corte del Rey Cristianísimo donde, cierto es que por recomendación muy elocuente del Duque de Vendôme, fue recibido y beneficiado con la concesión de algunas rentas. Extraordinaria fue también la consideración que el mariscal francés tuvo durante largos años al que llamaba su «querido abate», confiándole sus asuntos personales ${ }^{8}$. Más aún lo fue para la Reina Isabel, segunda esposa de Felipe V, quien gustaba de su compañía y consejos, permitiéndole el acceso a sus cámaras privadas y conferenciando con Alberoni sobre toda suerte de asuntos. Por mediación de la Reina, Felipe V confió asimismo en su Ministro, cuya honestidad defendió hasta el momento mismo de su caída.

\section{Primeros pasos en la Corte}

La privanza de Alberoni comenzó, en efecto, con la llegada a España de la nueva Reina Isabel de Farnesio, pero las bases firmes de su privilegiada situación las había asentado el Conde Alberoni mucho antes, en el tiempo en el que el joven monarca temía aún por su Corona. Fue entonces cuando Alberoni tocó en las puertas de la política española. Capaz, sin duda, de acomodarse a la que, en cada momento, fuese la circunstancia más propicia, se hizo un hueco en el círculo de la Princesa de los Ursinos, tan pronto como, desaparecido Vendôme, la continuidad de su carrera pasó a depender de su capacidad para desenvolverse en la tensa Corte española.

\section{I.I. A la sombra de Vendôme}

Alberoni llegó a España, en el otoño de I7ı́, acompañando al Duque de Vendôme. Por entonces había recorrido ya media Europa en compañía del Duque, al que siguió desde Italia a Francia, de ésta a Flandes y de nuevo a Francia, manteniéndose firme en su amigable relación incluso en el tiempo en que Vendôme estuvo retirado de la vida pública. Según SAN FELIPE, Alberoni servía, a su venida a España, como capellán en el séquito de Vendôme, estando «muy insinuado en la gracia del Duque»?. Poco se sabe en realidad, sin embargo, del cometido asignado a Alberoni en este tiempo, habiéndose

7 G. DREI, idem, recoge al respecto lo afirmado por el que pasa por ser el primer biógrafo de Alberoni, J. ROUSSET DE MISSY, autor de la obra titulada Historie du Cardinal Alberoni, et de son Ministre: jusqu' du fin de l'anne I7I9, publicada en La Haya, en I720, y vertida después al italiano.

8 Nacimiento del Cardenal Julio Alberoni y Compendio de su vida, en BNE, mss. I0.927, f. $4 \mathrm{v}^{\mathbf{0}}$.

9 Comentarios, cit., pág. 225. 
señalado que ejercía labores de Seretario o Consejero del Duque, para quien Alberoni habría sido una suerte de factotum general ${ }^{10}$.

Según advierten, entre otros, BOURGEOIS, Alberoni habría jugado un papel relevante en la rehabilitación para la vida pública del Duque de Vendôme ${ }^{\text {II }}$. El abate Alberoni contaba por ese tiempo ya con buenas relaciones en la Corte de Versalles, tratando con importantes personajes como el destronado Jacobo III de Inglaterra, el elector de Colonia, o el Duque de Alba. Merced a esos excelentes contactos, en I709 dirigió una carta al Conde Pighetti, enviado del Duque de Parma en la Corte de Francia, en la que, hablando en nombre de Vendôme, solicitaba que se cumplimentase al Duque de Alba, asegurándole su amistad y deslizando, seguidamente, el ofrecimiento de Vendôme como comandante de las tropas españolas ${ }^{\mathrm{I2}}$. La insinuación al Duque de Alba -a la sazón embajador español en París- acerca del deseo de Vendôme de tomar parte en la guerra de España, habría surtido $\mathrm{su}$ efecto ${ }^{\mathrm{I3}}$. La situación por la que atravesaba Felipe V era ciertamente complicada. Las tropas austracistas habían entrado de nuevo en Madrid, obligando a la Corte a retirarse a Valladolid. La pérdida de Zaragoza les había abierto también las puertas de Navarra, donde varias ciudades quedaron en poco tiempo bajo control de los aliados, que presionaban a Luis XIV -sometido asimismo a importantes derrotas en Centroeuropa- para que colaborase en la definitiva caída de la península bajo el control del ArchiDuque Carlos de Hausburgo. En este contexto, alarmado por los rumores que circulaban por la Corte acerca de un inminente abandono de Felipe $\mathrm{V}$ a su suerte, el Duque de Alba habría solicitado ser recibido por el Rey de Francia, desplegando ante él todas sus habilidades para convencerle de la necesidad de mantener el apoyo a su nieto ${ }^{\mathrm{I}}$.

Fuera o no cierta la intervención decisiva de Alberoni -referida por él mismo en algunos de los abundantes escritos que hizo circular en su defensa ${ }^{15}-$, lo cierto es que Vendôme fue requerido por Luis XIV para acudir en auxilio de su nieto, poniéndose, junto al Duque de Noailles, al frente de las tropas en la Peníncula. Quizá dudó Vendôme si debía abandonar su situación de retiro -y aquí sí podría haber jugado un papel determinante la capacidad de persuasión de su Secretario-, resolviéndose finalmente a regresar a España, donde, tiempo atrás, había contribuido a la conquista de Barcelona ${ }^{16}$. El mismo Alberoni comunicaba con entusiasmo a su tierra parmesana, en el verano de i709, que partía hacia

Io En estos términos J. LYNCH, El Siglo XVIII, cit., pág. 72. Por su parte, L. TAXONERA, El Cardenal Alberoni. Forjador de una nueva España en el siglo XVIII, Madrid, I943, págs. 29-30, le atribuye el papel de una suerte de Secretario de asuntos exteriores del Duque de Vendôme, al que habría correspondido principalmente ocuparse de ordenar su correspondencia con diferentes personajes de relieve.

II La diplomatie secrète au XVIIIe siècles. Tomo II: Le secret des Farnese: Philippe V et la politique des Farnese, París, I9ıo, págs. .62-64. En el mismo sentido, A. ARATA, Il proceso del card. Alberoni, dai doc. dell'Archivio Segr. Vaticano, Monografie del Collegio Alberoni, Piacenza, I923, pág. 6; G. DREI, Giulio Alberoni, cit., págs. 37-39, o F.M. TALIANI, El Cardenal Alberoni, Madrid, I953, págs. II-I2.

I2 La carta, fechada en I709, en G. DREI, Giulio Alberoni, cit., págs. 37-38.

I3 Sobre la embajada del IX Duque de Alba en París, D. OZANAM, "Los embajadores españoles en Francia durante el Reinado de Felipe V", en Felipe V de Borbón (I7OI-I746), coord. J.L. PEREIRA IGLESIAS, Córdoba, 2002, pp. 58I-6I2 y M.A. OCHOA-BRUN, “La diplomacia española durante la Guerra de Sucesión”, en Felipe V y su tiempo, edit. E. SERRANO, 2 vols., Zaragoza, 2004, I, pp. 700-723. Ninguno de esos trabajos menciona el episodio de la intervención de Alberoni.

I4 SAINT-SIMÓN, Mémoires, París, I892-I893, vol. XVIII, pág. 28. Por su parte, SAN FELIPE explica que la motivación del Duque de Alba fue en realidad una carta remitida por un buen número de nobles españoles que razonaban la necesidad de que se enviasen urgentemente socorros a España. La carta fue publicada por A. BAUDRILLART, Philippe V et la Cour de France. D'après des documents inédits des Archives espagnoles de Simancas et d'Alcala de Henares et des Archives du Ministère des Affaires Étrangères a Paris, París, I890, III, Appendice III, págs. 689-690.

I5 Así, por ejemplo, en la Carta de un Cardenal à el Marqués Granelli escrita desde Roma à I9 de Julio de I72I sobre asuntos del Cardenal Alberoni, en BNE, mss. II.I45, ff. I5r-vº.

I6 Sobre las dudas de Luis XIV y la insistente solicitud de ayuda por parte del Católico, A. BAUDRILLART, Philippe V, cit., III, págs. 369-377. 
España en compañía de su amigo el Duque, quien habría ofrecido a Alberoni la posibilidad de permanecer en Francia, asegurándole una posición desahogada mediante la concesión de un beneficio en Anet. La renta no era escasa, pero exigía residencia, de suerte que Alberoni, que por entonces disfrutaba ya otras rentas concedidas por el Duque de Parma y por el Rey Cristianísimo, rechazó la amable oferta de Vendôme y se dispuso a partir hacia España en su compañía ${ }^{\text {I7 }}$.

Una vez en España, Alberoni tuvo la oportunidad de introducirse en el ambiente palaciego. El mismo Vendôme habría recomendado su confianza a los Reyes, lo que le permitió ir acercándose a los jóvenes monarcas ${ }^{\mathrm{r}}$. La Corte se hallaba en ese momento en Valladolid, hacia donde se dirigió Vendôme tan pronto como llegó a España ${ }^{\text {r9 }}$. Allí habría conocido Alberoni a Felipe V y a la Reina María Luisa ${ }^{20}$, permaneciendo el abate en la Corte -que poco después había pasado a Vitoria, de donde la Reina se trasladó más adelante a Corella- recomendado por el Duque, hasta el regreso de éste después de la victoriosa campaña en el Ebro ${ }^{2 \mathrm{I}}$. Alberoni se introdujo pronto en el grupo formado por los Ministros italianos, en el que se contaban los Duques de Populi, Santo Buono y Giovinazzo, el príncipe de Cellamar y el Cardenal Giudice, hermano y tío, respectivamente, de los dos anteriores. Por ellos conoció las bambalinas de la Corte, en la que fue abriéndose un espacio con la Reina María Luisa y la intrigante Princesa de los Ursinos. Con ésta comenzó además a mantener correspondencia regularmente en nombre del Duque de Vendôme, dando de este modo satisfacción -según algunos relatos de la vida de Alberoni- al interés de Versalles por conocer de primera mano lo que ocurría en España ${ }^{22}$.

\section{I.2. Agente extraordinario del Duque de Parma.}

A comienzos del mes de junio de I7ı2, Alberoni informaba de la inesperada muerte del Duque de Vendôme a las Cortes de Versalles, Madrid y Parma. No resulta claro si Alberoni se trasladó o no a Versalles para dar cuenta personalmente a Luis XIV «del estado de los negocios de su difunto Señor», ni tampoco si su pronto regreso a España se debió a la voluntad del mismo Alberoni o al cumplimiento de un encargo realizado por el Duque

I7 BNE, mss. I0.927, Nacimiento del cardenal Giulio Alberoni y compendio de su vida, ff. $5 \mathrm{v}^{\mathbf{0}}-6 \mathrm{v}^{\mathbf{0}}$. El relato contradictorio acerca de la actitud de Alberoni con relación a Vendôme y a las razones que le llevaron a seguirle a España, alcanza también a la propia situación financiera de Alberoni y a la procedencia de las rentas de que disfrutaba en ese tiempo. Para su biógrafo español, L. TAXONERA, El Cardenal Giulio Alberoni, cit., págs. 3334, la pensión concedida por Luis XIV a Alberoni fue considerable y se debió a sus buenos servicios a la Nación y a la Monarquía francesas, de los que Vendôme había persuadido al tras su regreso a Francia, concluida la campaña italiana, queriendo de este modo asegurar la posición de su querido Secretario. Otras noticias, sin embargo, vinculan la concesión por parte de Luis XIV de una pensión a Alberoni a su actuación en Flandes, muy ponderada por el Duque a su regreso a París. En lo que parecen coincidir en todo caso unos y otros es en que Alberoni disfrutaba en ese tiempo de una posición desahogada, que le habría permitido declinar el ofrecimiento del Duque de Vendôme.

I8 F.M. TALIANI, El Cardenal Alberoni, cit., pág. I7. Según este autor, Alberoni estaba tan introducido en la Corte que le cupo la satisfacción de anunciar personalmente a los monarcas la victoria obtenida en Villaviciosa. Más lejos aún llega L. TAXONERA, El Cardenal Alberoni, cit., págs. 42-43, quien atribuye directamente a Alberoni el éxito obtenido por las tropas borbónicas. Por su parte, A. BAUDRILLART, Philippe V, cit., III, pág. 44I, presenta a Alberoni trabajando para unir a la Princesa de los Ursinos y a Vendôme. Señala este autor que la correspondencia entre la Ursinos y el Duque de Noailles, en los últimos meses de i7ıo, demuestra que estaba al corriente de todo.

I9 L. TAXONERA, El Cardenal Alberoni, cit. Págs. 4I-42.

20 Según refiere G. DREI, Giulio Alberoni, cit., pág. II, Alberoni habría tenido la oportunidad de ver de cerca de Felipe V unos años antes. En I7O2, en su ciudad de Piacenza, el jovencísimo habría sido agasajado con una fiesta a la que asistió Alberoni en compañía de los oficiales del estado mayor francés y de los españoles acantonados bajo el mando del Duque de Vendôme.

2I BNE, mss. I0.927, Nacimiento del cardenal Giulio Alberoni y compendio de su vida, ff. 7 r-v $\mathbf{v}^{\mathbf{0}}$.

22 La referencia -escasamente fiable, dados los frecuentes errores en que incurre el relato-, se halla en ibídem, ff. 6vº-7r. Se refiere a esta situación L. TAXONERA, El Cardenal Alberoni, cit., págs. 43-44. 
de Parma ${ }^{23}$. Las noticias acerca de la situación en que quedó Alberoni tras la muerte del Duque son poco claras. Según refiere PROFESSIONE ${ }^{24}$, Felipe V habría tenido la intención de enviar al abate Alberoni a Barcelona, donde el Duque de Popoli había dejado el puesto al Marqués de Creveveur, ofreciendo de este modo a Alberoni una oportunidad de asentarse tras la muerte de su protector, que tanto había recomendado su persona a los soberanos españoles. De hecho, el propio Alberoni, al participar a su amigo Rocca sus expectativas ante el nuevo empleo al que parecía destinado por el Duque de Parma, afirmaba que no le habrían faltado otros y que tan sólo la «tenerezza e la venerazione per il mio padrone e il mio devere di suddito» le habían llevado a aceptar permanecer en Madrid como representante del estado de Parma ${ }^{25}$.

El encargo de los negocios de Parma en España al abate Alberoni tuvo lugar a comienzos de I7I3. Por este tiempo, se habría resuelto sustituir al representante de los intereses del Ducado de Parma en la Corte de Madrid, el viejo Marqués de Casali, quien venía manifestando desde tiempo atrás su deseo de retirarse. El acceso de Alberoni a este empleo pudo producirse a finales del mes de enero ${ }^{26}$. Probablemente existe un error en la fecha del aviso recibido en el Consejo de Estado, que se dice de 3 de febrero de I7I5 podría ser de 3 de febrero de I7I3 - participando el haberse declarado al abad Alberoni enviado extraordinario en la Corte de Madrid ${ }^{27}$. Esta fecha es, quizá, la que lleva a señalar a PERONA $^{28}$ que Alberoni no tuvo al principio la representación oficial de la Corte de Parma, siendo más tarde señalado como enviado del Duque Farnese, aunque bien podría deberse asimismo a la noticia de la poco relevante posición que había alcanzado su predecesor Casali, o la de que éste no abandonó Madrid hasta finales del mes abril de $173^{29}$. El propio Alberoni aclara en cualquier caso que su posición en la Corte española, en su calidad de representante del Duque Francesco Farnese, fue reconocida desde el comienzo:

«Oggi io non solo sono considerato tale — señala en mayo de I7I3, después de afirmar que Casali solo había sido tolerado siempre como persona particular, sin haber alcanzado nunca un reconocimiento oficial—, ma di più incaricato degli affari del Duca di Parma, grazia accordatami dalle Maestà Cattoliche con grandissimo ribrezzo del Consiglio di Stato».

El desagrado del Consejo de Estado al que se refiere Alberoni tenía que ver probablemente con la rígida etiqueta de la Corte española y la humilde procedencia del abate. También esto trató de remediarlo el Duque Farnese, quien le concedió el título de Conde de Alberoni ${ }^{30}$. Por su parte éste se empeñó en dar a su nuevo encargo el lustre de que carecía. Para ello era preciso aparecer rodeado de la misma apariencia de que gozaban los miembros de otras legaciones diplomáticas en Madrid. La asignación que desde Parma se hacía llegar a su enviado en Madrid difícilmente cubría los gastos que Alberoni estimaba preciso acometer para dignificar su modesto empleo, lo que, según afirman algunos de sus biógrafos, le habría hecho contraer deudas, obligándole durante algún tiempo a aceptar la

23 En este sentido, Compendio de la vida de Julio Alberoni, en BNE, mss. I2.940, núm. I32.

24 Giulio Alberoni, dal I708 al I7ı4, Padua, ı890, págs. 43-44.

25 E. BOURGEOIS, Lettres intimes de J.M. Alberoni adressées au comte Rocca, ministre des finances du Duc de Parme et publiées dàprés le manuscrit du College S. Lazaro Alberoni, París, I892b, pág. 208.

26 En este sentido, A. PROFESSIONE, Giulio Alberoni, cit., págs.. 43-44.

27 Archivo General de Simancas [en adelante AGS], Estado, lib-reg. 4I5. El aviso fue publicado por B. BADOR, Los orígenes del Ministerio de Asuntos Exteriores (I7I4-I808), Madrid, I999, pág. 40.

28 Los orígenes del Ministerio de Marina. La Secretaría de Estado y del Despacho de Marina, I7I4-I808, Madrid, I998, pp. 66-67.

29 El mismo Alberoni comunicó la noticia de la salida del Marqués de Casali de Madrid dos días antes, Alberoni a Rocca, Madrid, 2 de mayo de I7I3, en E. BOURGEOIS, Lettres intimes, cit., pág. 2 I6.

30 A. PROFESSIONE, Giulio Alberoni, cit., pág. 43. 
hospitalidad del Duque de Popoli ${ }^{31}$. De la correspondencia entre Alberoni y el Conde Rocca, a la sazón responsable de finanzas en el Ducado de Parma, se desprende, sin embargo, que las numerosas exigencias del enviado en Madrid fueron por lo general atendidas, si bien se le llamó frecuentemente a contener unos gastos que él aseguraba una y otra vez que eran ajustados a las necesidades del empleo ${ }^{32}$.

El inicio de su misión debió satisfacer al Duque. Alberoni trabajaba mucho por los intereses de Parma, hasta el punto de lamentar ya en los primeros meses algún problema en la vista que le impedía enviar cartas más extensas a su amigo Rocca. La correspondencia oficial con su estado de Parma fue haciéndose, sin embargo, más frecuente y detallada, transmitiendo al Duque cuantas noticias tenía Alberoni de las cosas de España, del curso de las negociaciones de paz y de la —a su juicio lamentable — actuación en Cataluña, donde se estaba permitiendo a las tropas austracistas retirarse de forma lenta e inexplicable. En enero del año siguiente, el Duque Farnese parecía decidido a recompensar los esfuerzos de su representante, elevando su condición a la de enviado ordinario o residente en la Corte de España. Alberoni se apresuró a aceptar su nuevo encargo, que vendría a reconocer los esfuerzos que desde el comienzo había acometido para elevar la consideración del Ducado de Parma. Sin embargo, el intento tropezó con la creencia -que se extendió maliciosamente por la Corte- de que tan pronto como Alberoni se viese reforzado, abandonaría su empleo poniéndose inmediatamente a las órdenes del Rey de España o de cualquier otra Monarquía.

«Da tutto questo mal discorso -concluía Alberoni el lamento dirigido al Conde Rocca en el que apuntaba a la envidia de tantos como el motivo del fracaso de su empeñovi supplico restare persuaso che non troverete in me nè raggiri nè seconda intenzione, sperando mi si farà cosí la giustizia di credermi candido, puntuale e fedele, e che sarà a questa condizione che servirò e non altrimentì» ${ }^{33}$.

En efecto se mantuvo Alberoni constante y fiel en el desempeño de su encargo de enviado extraordinario de Parma hasta el final de I7I9, siendo éste el único empleo que oficialmente se le confirió durante su etapa española ${ }^{34}$.

\section{I.3. Primera misión oficial en la Corte española}

En el año en que Alberoni se estrenaba en su misión diplomática, la Corte española aparecía aún más convulsionada que de ordinario. Los partidos formados por franceses, italianos y el aún más dividido entre sí de los españoles pugnaban por intervenir en un Gobierno que comenzaba a liberarse de la dependencia de Francia que había marcado los primeros doce años del reinado del joven Felipe $\mathrm{V}^{35}$.

3I G. DREI, Giulio Alberoni, cit., pág. 47 y F.M. TALIANI, El Cardenal Alberoni, cit. pág. 23. La referencia al quebranto económico de Alberoni y a su relación con Popoli se contradice con las, asimismo referidas a este tiempo, que presentan a Alberoni recibiendo en su casa y en su mesa a cuantos personajes de relieve en la Corte estaban a su alcance.

32 Un resumen del contenido de las cartas cruzadas entre Alberoni, el Duque Farnese y el Ministro Rocca en los meses de mayo a agosto de I7I3, en P. CASTAGNOLI, Il Cardenale Giulio Alberoni, 3 vols., Piacenza, I929-I932, págs. I2I-I29. Aún en una carta de Alberoni a Rocca, del 4 de junio de I7I4, el abate continúa lamentando su mísera situación si se compara con la de los enviados en Madrid de otras Cortes, en E. BOURGEOIS, Lettres intimes, cit., pág. 3I3.

33 Alberoni a Rocca, Madrid, I5 de enero de I7I4, en E. BOURGEOIS, Lettres intimes, cit. pág. 276-277.

34 Cuando el 27 de julio de I7I7, la Gaceta de Madrid recogía la noticia de la concesión a Giulio Alberoni del Capelo cardenalicio se refería a él tan sólo como agente extraordinario del Duque de Parma en España.

35 La renuncia a sus derechos a la Corona francesa, en julio del año anterior, había despejado el camino para la defensa de sus intereses como de España. Sobre el particular y la reacción de Luis XIV, A. BAUDRILLART, Philippe V, cit., págs. 463-50I. Un análisis reciente de la presión francesa en la primera década del siglo en J.L. 
El trasfondo de las dilatadas negociaciones de paz — que irían concluyendo en el complejo sistema de equilibrio por medio de diversos tratados que conformaron la paz de Utrecht-Rastadt-, vertía mayor tensión sobre la Monarquía española, que parecía verse abocada a considerables cesiones. En ese marco, Alberoni, observador de excepción desde su puesto de enviado de una Corte extranjera, no dejaba de advertir del peligro cierto de unas negociaciones que parecían encaminadas a la salida del Rey Católico de Italia y la sumisión, a medio plazo, de esta Península al Emperador. Varias fuentes coinciden en apuntar que Alberoni ambicionaba jugar ya en ese momento un papel determinante en relación a Italia, trasladando al Duque Farnese, unos meses antes de la conclusión de la paz de Utrecht, su confianza en que desde Italia fuese requerida una intervención de Felipe V, en la que el mismo Alberoni podría desempeñar la función de intermediario ${ }^{36}$. Tal encargo no llegó a producirse, pero si se requirió la intervención del enviado del Duque de Parma para tratar con el enviado de la Reina Ana, Lexington, las condiciones de paz con $\mathrm{Su}$ Majestad Británica ${ }^{37}$. En su elección para tal empresa sin duda tuvo que ver la Princesa de los Ursinos, árbitro casi exclusivo en este tiempo de todos los negocios y a la que Alberoni habría ido tratando cada vez con mayor intimidad. La agasajaba frecuentemente con múltiples presentes que le hacían llegar desde Parma y que entusiasmaban a la Ursinos y su reducido círculo, introduciéndose de este modo, a través de ella, también con la Reina María Luisa, que se divertía en compañía de Alberoni, al que tenía cierta consideración y estima ${ }^{38}$.

La enfermedad de la Reina y su prematuro fallecimiento, el i4 de febrero de I7I4, abrirían nuevas expectativas para el ambicioso enviado de la Corte de Parma. No sólo Alberoni, sino el cuerpo diplomático presente en España en I7I4 en su conjunto, comenzó a moverse para procurar influir en la elección de una nueva esposa para Felipe V. Hacia finales del mes de abril la Corte parecía ya convencida de que el Rey volvería a casarse, haciéndose más evidentes las maniobras de los representantes de las Cortes de Baviera o Saboya, entre otras, que trataban de situar ante la mirada decisiva de la Princesa de los Ursinos a sus propias candidatas ${ }^{39}$. Varios meses antes, Alberoni había anunciado ya al Duque de Parma su secreto proyecto de patrocinar a la sobrina del Duque como futura Reina de España. En el mes de enero, había solicitado autorización para empeñarse en este cometido, a lo que Farnese respondió a Alberoni que debía ser cauteloso ${ }^{40}$. Alberoni se condujo, en efecto, con extraordinaria cautela. Poco después de fallecer la Reina, sugirió ya a la Princesa de los Ursinos que el Rey no podría permanecer mucho tiempo sin casarse, pero se cuidó en mostrar algún interés al respecto.

CASTELLANO, "El gobierno en los primeros años del Reinado de Felipe V. La influencia francesa”, en J.L. PEREIRA IGLESIAS (coord.), Felipe V de Borbón (I70I-I746): actas del Congreso de San Fernando (Cádiz) de 27 de noviembre a I de diciembre de 2000 , Córdoba, 2002, págs. I28-I42.

36 El texto de la carta de Alberoni al Duque Farnese, fechada en febrero de I7I2, es reproducido A. ARATA, Il processo, cit., pág. Io. Por su parte, F.M. TALIANI, El Cardenal Alberoni,cit., págs. 2I-22, refiere una confesión prácticamente idéntica a la apuntada, pero la pone en boca del Duque de Vendôme, señalando que pronunció esas palabras en presencia del , la Reina y del propio Alberoni.

37 G. DREI, Giulio Alberoni, cit., pág. 49 y F.M. TALIANI, El Cardenal Alberoni, cit., pág. 22. Según este último, nada tuvo que ver Alberoni en el pésimo resultado obtenido en el Tratado de I4 de marzo de I7I3, que venía impuesto por la exigencia del Cristianísimo de alcanzar en cualquier modo la paz.

38 F.M. TALIANI, idem, afirma que la Reina agradecía sus regalos y, cada vez más, apreciaba sus consejos. Con los mismos métodos fue atrayéndose a otros personajes influyentes, sentando a su mesa a muchos Grandes a los que agasajaba con exquisitos manjares que se hacía enviar desde Italia. El abate parecía estar en todas partes, conquistando a la Corte con su extraordinaria amabilidad. En el mismo sentido, G. DREI, Giulio Alberoni, cit., pág. 49.

39 Carta cifrada de Alberoni al Duque Farnese, Madrid, 30 de abril de I7I4, en Archivio di Stato di Napoli [en adelante, ASN], Farnese, fascio 54, fasc. 3. Su contenido en P. CASTAGNOLI, Il Cardenale Giulio Alberoni, cit., pág. 150. I5I.

40 Duque Farnese a Alberoni, febrero de I7I4, en respuesta a otra de éste del mes de enero, ibídem, pp. I50- 
Dos negocios principales ocupaban por esos meses a todos los observadores de la Corte española: el resultado de las negociaciones de paz de Rastadt y las implicaciones que de este acuerdo se derivasen para España, y el futuro matrimonio del Felipe V. Temiéndose que Luis XIV se inclinase definitivamente hacia la conclusión de cualquier acuerdo con el emperador, por perjudicial que fuese el tratado para España, se dispuso una embajada a la Corte del Rey Cristianísimo, para la que se eligió — sin duda también con otras intenciones menos explícitas - al Cardenal Giudice, inquisidor general y el más claro rival de la Ursinos en la confianza del monarca. Giudice partió a comienzos del mes de abril. Advertido el Ministro francés Torcy, se especuló con la posibilidad de que tratase de abordarse por mediación del inquisidor general la delicada empresa del matrimonio real ${ }^{4 \mathrm{~T}}$. El embajador francés en España, Marqués de Brancas, se puso inmediatamente en camino y forzando hasta el límite la marcha consiguió llegar a París tres días antes de que lo hiciera la embajada española. Giudice, que poco tenía que hacer ya en la Corte de Francia, al haberse concluido el acuerdo de Rastadt, se había visto, sin embargo, alejado de Madrid, donde su posición junto al Rey comenzó a desvanecerse, transformándose meses más tarde en un enconado enfrentamiento que retuvo al Cardenal en Francia hasta febrero del año siguiente. La firma del acuerdo de Rastadt entre Austria y Francia colocaba al Rey de España en una delicada situación. Alberoni, pendiente de los resultados para su patria parmesana, mostraba su desconfianza al Duque Farnese, que parecía sin embargo aliviado tras conocer los términos del acuerdo que, a su juicio, aseguraban la neutralidad de Italia. No lo tenía tan claro Alberoni, quien lamentaba, no obstante, tener una percepción pesimista ${ }^{42}$.

Simultáneamente Alberoni se ocupaba del otro asunto, que para él venía a ser el principal desde hacía varios meses: «Dal primo istante, che morì la Regina mi osi in aguato per penetrare ogni più profondo arcano, e promovere con tutta destrezza le disposizioni, quando l'avessi potuto credere favorevoli» ${ }^{43}$. Añadía Alberoni que no parecía mostrar aún el Rey signo alguno de querer contraer nuevo matrimonio, pero que la opinión general en la Corte era que no permanecería mucho tiempo sin casarse de nuevo. Informaba seguidamente de las maniobras de unos y otros y de su convencimiento en las posibilidades de la Princesa parmesana. Persuadido de que solo la Princesa de los Ursinos era la clave del negocio, insistía en agasajarla, trasladándose un par de veces por semana a El Pardo, donde se había retirado la Corte desde el final del mes de mayo, y aprovechando sus conversaciones para insistir en las bondades de la candidata Farnese ${ }^{44}$. A comienzos del mes siguiente, la Ursinos pareció decidida a favor de la sobrina del Duque de Parma. El io de junio se comunicó formalmente a Luis XIV por mediación del sobrino de la Princesa, el príncipe de Chalais y recibida la confirmación de que Luis XIV aprobaba la elección realizada por su nieto, se comunicó asimismo al pontífice, a través del embajador de España en Roma, Cardenal Acquaviva, quien debía dirigirse después a Parma para solicitar formalmente la mano de la Princesa Isabel a su tío el Duque Francesco Farnese.

Cerrado el capítulo del matrimonio, Alberoni se entregó a la nueva operación consistente en preparar la llegada de la Reina Isabel. Una operación plagada de intrigas en las que intervinieron la Reina viuda de Carlos II, alejada de la Corte de España y enemiga

4I Marqués de COURCY, L’Espagne après la paix d'Utrecht, I7I3-I7I5: la Princesse des Ursins et le Marquis de Brancas, Un grand inquisiteur d'Espagne a la cour de France. Les débuts d'une nouvelle reine, París, I89I, pp. I26-I27. Sobre la embajada extraordinaria del cardenal de Giudice y el nombramiento en el año siguiente de su sobrino, Antonio José del Giudice y Papacoda, príncipe de Cellamare, hijo del Duque de Giovenazzo, D. OZANAM, “Los embajadores españoles en Francia..", cit., págs. 592-593.

42 "Io, però, a dirvela, ne temo molto, e prego Iddio a essere un falso indovino", respondía el 23 de abril a la carta remitida por su amigo Rocca el 30 de marzo. Ambas en E. BOURGEOIS, Lettres intimes, cit., CCCXVI, págs. 303-304.

43 Carta parcialmente cifrada de Alberoni al Duque Farnese, i6 de abril de I7I4, en ASN, Carte Farnesiane, fascio. 54, fascic, 3, publicada. por P. CASTAGNOLI, Il Cardinale Giulio Alberoni, cit., Apéndice al cap. VIII, págs. I86-I88.

44 Alberoni a Rocca, 28 de mayo de I7I4, en E. BOURGEOIS, Lettres intimes, cit., CCCXX, pág. 308. 
declarada de la Ursinos, el Cardenal Giudice y hasta el mismísimo Luis XIV. Alberoni había cumplido más que satisfactoriamente su papel de valedor de los negocios del Duque Farnese en España, pero aún le quedaba algo por hacer. A mediados de diciembre, Alberoni anunciaba a la Corte de Parma la llegada de la Reina a Pamplona. En su calidad de representante de los Farnesio, Alberoni había acudido hasta allí a recibirla, conversando animadamente con la joven Reina a la que instruyó concienzudamente sobre lo que iba a encontrar en la Corte. La información suministrada por el abate Alberoni reforzó sin duda la decisión de la Reina Isabel de alejar cuanto antes de su entorno a la Princesa de los Ursinos. No en vano en los días previos a su entrada en España, la Reina se había detenido en la localidad fronteriza de San Juan a Pie de Puerto, en la que tuvo ocasión de conversar extensamente con su tía, María Ana de Neoburgo. La Reina viuda previno entonces a Isabel para que no se dejase gobernar por la intrigante Ursinos. Las explícitas recomendaciones que después realizó su compatriota Alberoni hicieron el resto. Instruida la Reina de los vericuetos de la compleja Corte española — tal como indicaba Alberoni al Duque Farnese una vez concluyó su misión en Pamplona-, el encuentro con la Princesa de los Ursinos en Jadraque tuvo el resultado que podía esperarse. La Reina conquistó el espacio que le correspondía y la hasta entonces todopoderosa Ursinos se vio alejada de Madrid, de Felipe V a quien había servido tantos años, de sus amigos y de sus anteriores manejos en el Gobierno de España.

\section{Alberoni, favorito de los Reyes}

En el comienzo de I7I5, Alberoni seguía siendo el enviado extraordinario de la Corte de Parma en Madrid. Pero indudablemente la situación había cambiado enormemente en relación a aquella que encontró en el inicio de su misión dos años atrás. De una parte, una Princesa parmesana ocupaba entonces el trono de España y, además, se había producido un vuelco extraordinario en el gobierno. La caída de la Ursinos —que definitivamente había abandonado España al final del mes de diciembre- auguraba las que poco después iban a producirse en su entorno y con éste se removerían también las bases de la nueva estructura de gobierno que apenas había comenzado a asentarse. La Reina, que había dado muestras de considerable firmeza ya antes de llegar a Madrid, no estaba dispuesta a retroceder. Asesorada por su fiel Alberoni, compartía con Felipe V todos los minutos del día, introduciéndose de este modo también en los negocios de la Monarquía.

Se abría a partir de ese momento una nueva etapa en el reinado del primero de los Borbones españoles. Un nuevo período que arranca con una auténtica convulsión política, a la que suceden dos años de sosiego en los que va afianzándose la idea de considerar inaceptables los resultados del sistema impuesto en Utrecht. El afán revisionista de Felipe V pone sus miras en Gibraltar, en Menorca y, sobre todo, en Italia. Fortalecido por la presión de la Reina, empeñada, asimismo, en la recuperación de una presencia española en Italia capaz de asegurar un trono para sus hijos ${ }^{45}$. Junto a ambos, alentando sus decisiones y conduciendo bajo sus indicaciones algunas de las complejas negociaciones diplomáticas entre I7I5 y I7I6, está Alberoni. Alberoni que aparece como el principal apoyo de la Reina, que continúa desempeñando con igual celo su papel de representante diplomático del Duque Farnese en Madrid y que, día tras día, gana posiciones junto al monarca. Alberoni, que estará decididamente al frente de los principales negocios de la Monarquía española en el tiempo en que, apenas dos años más tarde, estallen de nuevo las hostilidades.

45 Como advierte M.V. LEÓN SÁNZ, “La llegada de los Borbones al trono”, en R. GARCÍA CÁRCEL (coord.), Historia de España. Siglo XVIII. La España de los Borbones, Madrid, 2002, pág. 62, la política revisionista española se orientó a la recuperación de los territorios perdidos en la península itálica, proyecto en el que coincidían la voluntad irredentista de Felipe V y la ambición italiana de Isabel de Farnesio que veía en ellos la posibilidad de asegurarlas para sus propios hijos, 


\section{I. Consejero de la Reina}

El 3i de diciembre de I7I4, pocos días después de la entrada de la nueva Reina en Madrid, Alberoni respiraba satisfecho por lo alcanzado. En una relación remitida al Duque de Parma describe alborozado el golpe que había supuesto la decisión de la Reina de apartar a la Ursinos y como con éste único gesto había logrado asegurar su ascendiente sobre el Rey $^{46}$. El enviado del Duque Farnese es consciente de haberse dado ya el primer paso, el principal, el que le permitiría colocarse en la posición desde la que con tiempo y paciencia podría aspirar a lo más alto.

El papel que con entusiasmo asumió Alberoni desde finales del mes de diciembre era el de confidente, consejero y principal apoyo de la joven Reina ${ }^{47}$. Un papel que venía desempeñando en realidad desde meses atrás, cuando desde la distancia transmitía puntualmente a Parma noticias sobre la Corte española y diversas recomendaciones acerca de cómo debería conducirse en ella la Princesa parmesana para actuar con acierto ${ }^{48}$. Después, en su primera conversación con la Reina en Pamplona, en la que se confirmaron las expectativas que ambos interlocutores hubieran podido formarse acerca del otro, quedó definitivamente establecida entre ambos una firme alianza ${ }^{49}$.

Isabel de Farnesio se sirvió del apoyo de Alberoni para comenzar a moverse en una Corte que le era extraña, dejándose conducir y escuchando sus opiniones sobre los asuntos de gobierno en los que se introdujo muy rápidamente. Alberoni, que se sabía respaldado por la Reina, procuró controlar absolutamente el entorno de la joven, evitando que se aproximasen otros que pudieran estorbar su privanza. En este sentido, SAN FELIPE refiere que se nombró al príncipe de Cellamare para el empleo de caballerizo de la Reina y al padre Domingo Guerra para ocupar su confesionario, siendo ambos nombramientos de la factura de Alberoni. Fue asimismo designada camarera mayor de la Reina la señora Condesa de Altamira ${ }^{50}$. Más sorprendente resulta, sin embargo, el que se atribuyesen las funciones de Secretario de la Reina al Marqués de Grimaldo ${ }^{5 \mathrm{I}}$ a quien Alberoni habría conocido poco después de su llegada a España cuando, en compañía del Duque de Vendôme, se presentó en la Corte. Así lo explica el mismo Grimaldo años más tarde, afirmando que, tras aquel primer encuentro en Valladolid, tuvo después mayor comunicación con Alberoni en el año I7I4 «en ocasión del casamiento del Rey con la Reyna nrâ señora», habiéndole merecido entonces alguna confianza, si bien después la relación «se fue entibiando y casi llego a terminos de una entera aunque tacita desconfianza, pareciendole que la demasiada venignidad con que el Rey me mantenia a sus pies, podia con el tiempo ser perjudicial a sus ideas» ${ }^{52}$. A juicio de Concepción de CASTRO ${ }^{53}$, fue ciertamente la confianza

46 ASN, Farnesiane, fasc. 54, fascic. 2.

47 Para G. COXE, España bajo el Reinado de la Casa de Borbón. Desde I700, en que subió al trono Felipe V, hasta la muerte de Carlos III, acaecida en I788, 4 vols., Madrid, I846, II, pág. I44, «el principal consejero de aquella Princesa ambiciosa, su maestro en la ciencia política, era Alberoni, quien como paisano y causa de su elevación, fue su guía y el depositario de sus más secretos pensamientos».

48 E. ARMSTRONG, Elisabeth Farnese. The Ermagant of Spain, Londres, I892, pág. 20.

49 Así lo señala M.A. PÉREZ SAMPER, Isabel de Farnesio, Barcelona, 2003, p. 77. Para C. de CASTRO, A la sombra de Felipe V. José de Grimaldo, Ministro responsable (I703-I726), Madrid, 2004, pág. 322, Alberoni disfrutó de la confianza de la Reina desde que la acompañara en el viaje a España y desde el principio habría venido actuando como jefe de su casa.

50 Gaceta de Madrid, del 8 de enero de I7I5. Sobre la elección del confesor, SAN FELIPE advierte que llamó la atención al tratarse de una persona de vida ejemplar, nada ambiciosa y «de muy moderadas prendas para tan alto empleo».

5I La referencia al nombramiento de Grimaldo puede verse en Gaceta de Madrid, del 8 de enero de I7I5. Al respecto, G. COXE, España bajo el Reinado de la Casa de Borbón, cit., II, pág. I37.

52 AHN, Estado, 2884/3.

53 A la sombra de Felipe V, cit., págs. 306-307. 
que el Rey tenía en su Secretario lo que permitió a Grimaldo mantenerse en el comienzo de I7I5 e ir ganándose también la confianza de la Reina.

En todo caso el hombre de confianza, el confidente y apoyo de la Reina no era otro que Alberoni, al que se abrieron las puertas de los reales aposentos, permitiéndole mantenerse en permanente contacto con los Reyes a los que acompañaba también en sus frecuentes partidas de caza, aprovechando todos los instantes en que podía hacerse escuchar por la Reina para comunicarle sus recomendaciones. La correspondencia de Alberoni con Rocca en los primeros meses de I7I5 refleja el ánimo de quien se sabe cada vez más seguro. En tono exultante explica que los Reyes le han distinguido con el honor «che non ha esempio, dell'ingresso anche più segreto, onde, come sin hora hanno mangiato nella camera interiore della Regina, ho havuto l'honore di assitere a tutti $i$ pranzi e cene», o informa de los rápidos progresos de la Reina en el ámbito de los negocios y de cómo él continúa asistiendo «ai piedi di S.M. ed in quello va occorrendo e che mi dice»»" Se atribuye Alberoni haber aconsejado a Felipe $\mathrm{V}$ que hiciese participar a la Reina en la dirección de la Monarquía y refiere los grandes progresos que la joven Isabel había realizado en poco tiempo y que le llevan a afirmar, a finales de enero de I7I5, que «fra poco tempo il Re potrà dire d'havere un buono primo Ministro» ${ }^{55}$.

Alberoni era, pues, al propio tiempo una suerte de mentor de la Reina, a la que iba introduciendo en los intrincados negocios del gobierno, y su principal asistente. Con su conocida habilidad para dar a cada uno lo que precisaba en cada momento, trabajaba infatigablemente para que en la mesa de los Reyes no faltasen las ricas viandas procedentes de Parma que tanto gustaban a la Reina, o para que ésta contase con los mejores caballos o los más ricos tejidos con que confeccionar sus vestidos ${ }^{56}$. Por indicación de Alberoni se disponía así el pago, con cargo a la cuenta consignada a la Reina para gastos de su Real Cámara y Bolsillo, de diferentes enseres o trabajos realizados para Su Majestad ${ }^{57}$.

Ya antes de la llegada de la Reina a Madrid había hecho encargar Alberoni ricos presentes para ella ${ }^{58}$ y posteriormente incrementó considerablemente sus atenciones, lo que le ocasionó algunos problemas con la Corte de Parma que, una vez más, le recriminó el exceso en los gastos, llamando la atención sobre la considerable diferencia con los realizados por otros enviados del Duque. La réplica de Alberoni fue aún más contundente que lo había sido dos años atrás:

54 E. BOURGEOIS, Lettres intimes, cit., CCCXLIV, 7 de enero de I7I5, págs. 354-357 y CCCXLVI, 2I de enero de I7I5, págs. 360-36I.

55Para G. DREI, Giulio Alberoni, cit., págs. 70-7I, si la Reina, que tenía pasión por el poder, devino pronto el primer Ministro del , Alberoni fue a su vez el primer Ministro de la Reina.

56 La conocida afición de la Reina Isabel de Farnesio a los placeres de la buena mesa fue aprovechada con tino por Alberoni, que daba cuenta puntual a su amigo Rocca del buen estado de la salud de la Reina y de las múltiples atenciones que él se desvivía en procurarle. Sobre el particular, M.A.PÉREZ SAMPER, Isabel de Farnesio, cit., págs. 330 y ss; de la misma autora, "La alimentación en la Corte de Felipe V", en E. SERRANO (edit.), Felipe V y su tiempo. Congreso Internacional. 2 vols., Zaragoza, 2004, págs. 529-583 y "La alimentación en la Corte española del siglo XVIII”, en Cuadernos de Historia Moderna, 2 (2003), págs. I53-I97.

57 En AHN, Estado, 2884/2, pueden verse diferentes órdenes de pago dirigidas al tesorero de S.M. y firmadas por el Conde de Alberoni. La cantidad consignada en la cuenta de la Reina desde $\mathbf{I}^{\mathbf{o}}$ de diciembre de I7I4 ascendió a 80.000 escudos de vellón, de la que fueron abonándose «diversas cantidades por papeles del Sr. Conde de Alberoni».

58 «Recibí del Excmo. Sr. Enviado de Parma, por manos del Sr. D. José Bermasque, la cantidad de diez doblones de a dos escudos cada uno, a buena quenta del bestido que e de bordar a la Reina nuestra señora. Madrid, 7 de octubre a 24 de I7I4. D. Pedro de La Torre», en AHN, Estado, 2884/2. 
«Io venero tutti $i$ miei antecessori e per loro ho molta stima e rispetto - señala a mediados de marzo de I7I5-, però oggi coll'havere lhonore di servire una Regina di casa Farnese, penso, e con ragione, d'essere superiore a tutti»"

En la misma carta afirmaba no entender por qué disgustaba al Duque que su enviado en la Corte de España tuviese una noble posición, sosteniendo que era él mismo quien la costeaba de su propio peculio. Recordaba que siempre había sido un hombre honrado y concluía señalando «procureró di partire di qui con tale concetto. Io non pretendo che facciate per me miracolil; però non crediate che io tampoco li possa fare a lungo». No obstante la advertencia, Alberoni continuó actuando de igual manera, orgulloso de aparecer como la "Nodriza de la Reina", pendiente de todo lo que ésta precisase ${ }^{60}$.

El papel desempeñado por Alberoni junto a la Reina suscitó sin duda la envidia de muchos y provocó una notable inquietud en la Corte francesa que, tras la salida de la Ursinos, trató de ocupar el espacio dejado por ésta, advirtiendo tempranamente que el puesto de consejero hacía tiempo en realidad que estaba reservado a Alberoni.

\subsection{Privado y Cardenal}

El papel desempeñado por Alberoni junto a los Reyes en el período conocido como «quinquenio Alberoni» (I7I5-I7I9) ha sido caracterizado por LYNCH como «privanza informal», basada en su posición de favorito de la Reina, con cuyos intereses aparecía claramente identificado Alberoni. Según el historiador inglés, con Alberoni se sustituía el modelo francés de gobierno, por el dominio de los favoritos, típico de los Austrias, siendo Alberoni el primero de estos nuevos «Validoss» ${ }^{6 \mathrm{I}}$.

La llegada de la nueva Reina y el nacimiento, a comienzos de i7i6, del primero de los hijos de Isabel de Farnesio, hicieron sentir a Alberoni definitivamente asentado en su privanza. Fue distinguido con el honor de actuar como padrino -en representación del Duque de Parma- en el bautizo del infante don Carlos, que se celebró en los Jerónimos en febrero de I7I6 y en el que la madrina, asimismo ausente y representada por la Condesa de Altamira, fue la tía abuela del recién nacido, doña María Ana de Neoburgo. La Reina tuvo en adelante una ocupación principal, asegurar la posición de sus propios hijos, de suerte que se incrementó su intervención en el gobierno respaldando la política italiana a la que Felipe V parecía inclinado. Para ello supo que tenía que contar con la habilidad de su consejero en el ámbito de las relaciones internacionales. Entre los años I7I5 y I7I6, Alberoni se ocupó principalmente en los negocios relacionados con las complejas relaciones entre Francia y España. Fue él también quien negoció sendos tratados con Inglaterra, con la vista puesta en asegurar la neutralidad de los ingleses en un futuro escenario de nuevo enfrentamiento con el emperador por el dominio de Italia.

Después, la renuncia del Cardenal Giudice a su empleo de inquisidor general y su definitiva salida de España, dejaron expedito el camino a Alberoni, que, no obstante, continuaba actuando con cautela, preparando poco a poco las bases de las reformas que le permitirían poco después intervenir decisivamente en todos los negocios de la Monarquía. En este tiempo Alberoni intensifica sus esfuerzos. De su correspondencia con el Ducado de Parma se desprende el calado de las reformas que pretenden introducirse y que alcanzan a la organización misma de la Corte, cuyo desorden obsesiona a Alberoni desde el comienzo, al conjunto de las instituciones que conforman la Administración central, a la hacienda, a la

59 Alberoni a Rocca, II de marzo de I7I5, en E. BOURGEOIS, Lettres intimes, cit., CCCLI, págs. 378-384.

6o Recoge esta expresión G. DESDEVISES DU DEZERT, La España del Antiguo Régimen, trad. de A.L. González e introducción de A. González Enciso, Madrid, I989, págs. 260 y 269. Según Desdevises, Alberoni se desvivía en ocasiones en cortesías propias de un criado,

6I J. LYNCH, El Siglo XVIII, cit., pág. 73. 
moneda, al comercio con América, o a las diversas fábricas de manufacturas que planea establecer ${ }^{62}$.

Alberoni, quien lamenta contar con escasos apoyos en su gestión, irá rodeándose a lo largo de I7I7 de sus propias criaturas. En enero de I7I7, logró situar al frente de la Tesorería mayor a Nicolás de Hinojosa; poco después se envió a José Patiño a Cádiz y, en abril del mismo año, reformada la planta de las Secretarías del Despacho, el Marqués de la Compuesta se hizo cargo del nuevo Departamento de Justicia, Gobierno Político y Hacienda $^{6_{3}}$. En relación a Patiño, afirma Alberoni, meses más tarde, que constituye su único apoyo, recordando una vez más la penosa situación del Gobierno, en el que, poco a poco, iban introduciéndose los cambios que permitirían dar a la Monarquía española el impulso que precisaba ${ }^{64}$.

Por este tiempo es ya Alberoni quien comparte con el monarca el peso del Gobierno. Preside Juntas de Gobierno que, por esta razón, se reúnen en su casa, se dirige a Ministros, Secretarios, consejeros o embajadores requiriendo informes o transmitiendo órdenes en nombre del Rey. Pero Alberoni no ha recibido nombramiento o poder alguno que le faculte para conducirse de ese modo. Es su proximidad al monarca, la estrecha relación que desde años atrás le une a la Reina y, a través de ella, también a Felipe V, la única base de su poder, como lo ha sido siempre. Pero su intervención en los asuntos de gobierno no parece limitarse ahora ya a los encargos particulares que, en el ámbito de las relaciones internacionales, se le han ido confiriendo en diferentes momentos. No se reduce tampoco a trasladar, en privado, su parecer a los Reyes. Su colaboración es notoria, conociéndose por todos que goza de la confianza y el respaldo de Felipe V, quien no duda tampoco en favorecerle de diferentes maneras, de suerte que Alberoni fue recibiendo gratificaciones que le permitieron incrementar su nada desdeñable fortuna ${ }^{65}$. Alberoni obtuvo, además, de manos del Rey la administración del Obispado de Tarragona ${ }^{66}$.

En el verano de I7I7 Alberoni habría recibido asimismo el Capelo cardenalicio, siendo poco después propuesto por Felipe $\mathrm{V}$ para el Obispado de Málaga, que renunció al punto al resultar vacante el arzobispado de Sevilla, proponiéndosele para ésta y negándose desde la Santa Sede la confirmación y expedición de la correspondiente bula, lo que suscitó a la postre la ruptura de relaciones entre España y Roma, retornándose a una situación

62 Algunos de los estudios sobre el cardenal Alberoni publicados en Italia en la primera mitad del siglo pasado sostienen que las primeras medidas reformistas impulsadas por este Ministro en I7I7 tuvieron por objeto a la Casa del . En efecto, cuando tres décadas más tarde el Marqués de la Ensenada se interesó asimismo por la reforma de las Casas Reales, recibió un detallado informe del alcance de las reformas introducidas por Alberoni. Sobre este particular, C. GÓMEZ CENTURIÓN, "La reforma de las Casas Reales del Marqués de la Ensenada", en Cuadernos de Historia Moderna, 20 (I998), págs. 59-84 y M. RODRÍGUEZ GIL, La nueva planta de la Real Casa: los oficios de contralor y grefier generales, Madrid, I989.

63 Sobre el juicio que merece el nuevo titular del Departamento de Hacienda, Alberoni a Rocca, a fines de I7I6, en E. BOURGEOIS, Lettres intimes, cit., CCCCXLIV, págs. 509-5II.

64 Alberoni a Rocca, Segovia, I8 de mayo de I7I7, en ibídem, CCCCLXVIII, págs. 539-54I.

${ }_{65}$ Así, por ejemplo, en noviembre de I7I7 se concedieron al cardenal Alberoni 24.000 ducados de renta al año, de bienes confiscados y secuestrados, en concepto de astilla, debiendo percibirlos con efectos de $\mathrm{I}^{\mathbf{0}}$ de julio de ese año y declarándosele exento del pago de la media anata. La Real cédula despachada el i6 de noviembre de I7I7 por la que se comunicó la concesión al juez de bienes confiscados y secuestrados, aparece refrendada por el Marqués de la Compuesta y puede verse en AHN, Estado, 2884/I.

66 En una carta dirigida a su amigo Rocca el 3 de enero de I7I8, Alberoni explicaba el alcance de lo que se le había concedido, en E. BOURGEOIS, Lettres intimes, cit., CCCCSCVI, págs. 565-566. Tiempo después, sin embargo, no dudaba en afirmar que se le habían concedido esas rentas no como ecónomo o administrador de la sede episcopal, sino a título de usufructuario, en calidad de alimentos destinados a sostener su condición de cardenal. En AHN, Estado, 4830, pueden consultarse un manifiesto en defensa de las regalías de la Corona, una escueta nota planteando las dudas acerca de la condición de administrador o usufructuario de las rentas y sendas comunicaciones dirigidas por Alberoni a Luis de Miraval, presidente del Consejo de Castilla, en relación con este mismo asunto, todos ellos correspondientes al verano de I7ı. 
similar a la registrada en I709 y que el mismo Alberoni había contribuido a corregir, negociando a lo largo de i7i6 un acuerdo que fue concluido en el año siguiente ${ }^{67}$.

La muerte de la Reina María Luisa, el nuevo matrimonio de Felipe V y las consecuencias que tuvo en el Gobierno la salida precipitada de la Ursinos, habían abierto una nueva etapa en la que las conversaciones con la Santa Sede fueron dirigidas por el nuevo Ministro de Estado -el Cardenal Giudice- al que se encomendó también el tratamiento de los asuntos de naturaleza eclesiástica, el confesor Daubentón y el entonces abate Alberoni. La participación de este último, que Antonio MESTRE ${ }^{68}$ estima absolutamente decisiva para obtener dos años más tarde la conclusión del Concordato, habría comenzado en los últimos meses de I7I4, cuando, mientras cultivaba aún la confianza de la Princesa de los Ursinos, mantenía correspondencia regular con el Cardenal Giudice, que se encontraba aún en París. Tras el regreso de éste, se habrían retomado las conversaciones con Aldrovandi, representante de la Santa Sede, dilatándose a lo largo de todo el año sin que se avanzase gran cosa. A partir de febrero de I7I6, era ya Alberoni quien aparecía al frente de la parte española, impulsándose una interesada relación entre éste y Aldrovandi, de la que ambos esperaban obtener ventajas personales ${ }^{69}$. De hecho, como recuerda MESTRE, Alberoni supo gestionar adecuadamente los tiempos, de suerte que las negociaciones llegaron finalmente a puerto al tiempo que el Ministro parmesano obtenía el Capelo de Cardenal, aceptándose por Roma en Breve expedido el io de julio y remitido a la Corte española el 26 de agosto de $17 \mathrm{I} 7^{70}$.

Sin embargo, la normalización de las relaciones entre España y Roma se vio bruscamente alterada de nuevo apenas un año después. La nueva ruptura tenía lugar en un contexto de abierta crisis internacional, en el que España se enfrentaba una vez más a las potencias europeas en defensa de sus posiciones en Italia ${ }^{7 \mathrm{~T}}$. Alberoni, que había obtenido la dignidad de Cardenal en el verano de I7I7, se vio inmerso en un conflicto que desata nuevos vientos regalistas en la Corte española. La excusa esgrimida desde la sede romana para retardar la expedición de las bulas confirmando a Alberoni en el arzobispado de Sevilla para el que había sido propuesto por le Rey -diferentes agravios relativos a algunos obispados de Cataluña ${ }^{72}$ - dio paso en Madrid a diferentes consultas dirigidas a expertos teólogos y canonistas y al Consejo de Castilla, requiriendo se manifestasen en relación a lo que se entendía como una vulneración de las regalías de la Corona. Así lo estimó efectivamente el Consejo de Castilla en consulta de 26 de abril de I7I 8 , instando al monarca

67 Sobre los valores del Arzobispado de Sevilla, se apunta que importaban al año I20.463 escudos de vellón, elevándose los gastos de administración a 6.929 escudos e importando las pensiones I9.840, de lo que resultaba líquido anualmente, 93.694 escudos de vellón, AHN, Estado, 2884/2.

68 Prólogo a J.F. ALCÁRAZ GÓMEZ, Jesuitas y Reformismo: el padre Rávago, Valencia, I995, pág. IV.

69 Según SAN FELIPE, Comentarios, cit., pág. 265, refiere la decisiva intervención de Aldrovandi en la aspiración de Alberoni a la condición de cardenal, indicando que al no estar entonces normalizadas aún las relaciones entre Madrid y Roma, Aldrovandi, que también aspiraba al Capelo, se dedicó a cultivar a Alberoni, favoreciendo sus progresos a la vista del papa.

70 A. MESTRE SANCHÍS, "La Iglesia y el Estado. Los Concordatos de I737 y I753”, en Historia de España, dir. M. MENÉNDEZ PIDAL, tomo XXIX, vol. I, Madrid, I985, cit., págs. 277-333.

7I Un análisis detenido de la intervención española en Sicilia y Cerdeña, en M.A. ALONSO AGUILERA, La conquista y el dominio español de Cerdeña (I7I7-I720), Valladolid, I977.

72 Ver al respecto la carta remitida al Marqués de Grimaldo por el cardenal Aquaviva, Roma, 20 de abril de I7I8, en AHN, Estado, 2884/2, en la que se hace eco de los argumentos desplegados por la Santa Sede para retrasar la expedición de las bulas confirmando la provisión del arzobispado de Sevilla a favor del cardenal Alberoni. 
a hacer valer sus derechos, al tiempo que se aconsejaba la debida prudencia y firmeza en los requerimientos que se dirigiesen a la Santa Sede ${ }^{73}$.

\section{Cese, persecución y rehabilitación pública}

El 5 de diciembre de I7ı9, Felipe V disponía el cese de quien en los últimos años había sido su hombre de confianza en el gobierno de la Monarquía ${ }^{74}$. Giulio Alberoni, que había sabido hasta entonces sortear otros intentos de apartarlo de la confianza de los Reyes $^{75}$, se veía irremediablemente inmolado ahora en el altar de la paz europea, en pro de unas negociaciones que se prolongaron aún varios años hasta el Congreso de Cambrai. Casi simultáneamente a la conclusión del nuevo acuerdo de paz, Alberoni era exculpado de los cargos que se le habían imputado desde su caída en desgracia, tras una persistente persecución que duró tanto como la consecución del restablecimiento del nuevo equilibrio europeo.

\section{I. El cese y los documentos en poder de Alberoni}

La separación, que sin duda indignó a Alberoni, fue aceptada con buen talante, como parte del juego político ${ }^{76}$. «Era - decía, manteniendo hasta el final el tono del Ministro poderoso que había sido- il minore sacrificio che si poteva fare per dare la pace all'Europa»'

En los días que siguieron a su separación, Alberoni trató en vano de entrevistarse con los Reyes ${ }^{78}$. En apenas una semana, se afanó además en disponer sus asuntos,

73 Copia de la consulta del Consejo de Castilla de 26 de abril de I7I8, con motiuo de retardarse la expedición de las Bullas de ArzObispo de Seuilla a fauor del Cardenal Alberony, en ibídem.

74 BNE, mss. I0.927, ff. I8r-I9r, Decreto del Nro. Sr. Dn. Phelipe $5^{\circ}$ en que separa del Ministerio à el Cardenal Alberoni. El tenor, casi literal, del mismo lo incorpora el Marqués de SAN FELIPE, Comentarios, cit, pág. 3I8. San Felipe ofrece una crónica precisa de cuanto aconteció en relación al cese de Alberoni en los días que siguieron a la notificación del cese y hasta su salida de España. Un relato menos riguroso de lo sucedido durante esos días en la Corte, así como la transcripción del decreto de cese, en P. MASSUET, Historia del Duque de Riperdá, cit., págs. 85-87.

75 Durante su privanza fue objeto de, al menos, dos tramas para hacerlo caer. La primera tuvo lugar en el verano de i7i6 y fracasó debido a la rapidez con la que el Ministro italiano interceptó los movimientos del viejo consejero de Felipe V, Marqués de Louville, que, bajo la apariencia de prestar acomodo al embajador francés Saint-Aignan pretendía llegar hasta el monarca, socavando la influencia que en él ejercían la Reina y el partido italiano. En la conspiración contra Alberoni, el Duque de Orleans pensó que contaría con la complicidad del confesor Daubentón y del cardenal del Giudice, dolido por su reciente separación del gobierno. Alberoni que receló inmediatamente del doblez de Louville alertó al monarca, disponiéndose, a través del Secretario del Despacho de Estado el despido del Marqués sin ser recibido por el monarca.

Más próximo en el tiempo a aquella conjura que concluyó con la caída en desgracia de Alberoni, se habría fraguado otro complot en el que el embajador francés en Madrid, Saint-Aignan debía procurar el levantamiento de la nobleza descontenta, haciéndoles ver que la Monarquía española quedaría irremediablemente en manos del partido italiano si el, que poco antes había estado gravemente enfermo, fallecía. Paralelamente se instó la formación de la llamada Junta chica, que procuró, sin éxito, la caída de Alberoni.

76 Al día siguiente de conocer su cese, apartado del favor real, escribía al Duque de Parma dándole cuenta de la noticia y afirmando que la había aceptado con la debida resignación. ASN, Farnesiane, fasc. 58, fascic. 2, pub.. por P. CASTAGNOLI, Il Cardenale Giulio Alberoni, cit., II, pág. 380.

77 Alberoni al Conde Rocca, Madrid, 6 de diciembre de I7I9, en E. BUORGEOIS, Lettres, cit., pág. 634.

78 L. TAXONERA, El Cardenal Alberoni, cit., págs. 23I-232, sostiene que se le impidió moverse de Madrid - los se encontraban en El Pardo-, pero que si obtuvo permiso para escribir una larga carta a Felipe V «con una serie de alegaciones que eran otras tantas explicaciones justificativas de su conducta». La carta que, probablemente, no llegó a manos del, surtió, no obstante, según Taxonera, el efecto contrario, reiterándosele la orden de extrañamiento y reduciendo el tiempo de que disponía para rendir cuentas y abandonar la Corte. 
recibiendo en su residencia a quienes quisieron despedirle ${ }^{79}$. Los papeles de gobierno fueron recogidos de casa de Alberoni, de conformidad con lo que se le había ordenado, reservándose hábilmente el Cardenal los que consideró podrían ser después de interés para su defensa. Hizo entrega además al nuevo representante de la Corte de Parma, el Marqués Annibal Scotti, de los papeles tocantes a su ministerio como agente extraordinario en Madrid del Duque Farnesio. Y se dispuso, por último, a ordenar sus pertenencias, con las que se formaron varios cajones que se despacharían a su destino en Génova desde el puerto de Alicante, llevando asimismo consigo Alberoni otros tantos que habrían de embarcarse con él en Gerona. Hacia este último punto partió Alberoni el día in de diciembre. Al día siguiente, la Gaceta de Madrid publicaba la noticia de la exoneración del Cardenal, precisando que podría regresar a Italia ${ }^{8 \circ}$.

En su camino hacia la frontera, el equipaje del Cardenal Alberoni fue objeto de un concienzudo registro a cargo de oficiales reales. Más adelante la comitiva fue asaltada por un grupo de bandoleros, obligando al Cardenal a huir precipitadamente hacia la frontera, que pudo franquear sin problemas al contar con los pasaportes expedidos a su favor que le permitirían atravesar tierras francesas en su camino hacia Génova ${ }^{{ }_{1}}$. Precisamente a la espera de que llegasen los pasaportes, Alberoni se había detenido durante unos días en Zaragoza, donde recibió la primera comunicación del Secretario de Estado y del Despacho de Estado, Marqués de Grimaldo, requiriéndole la entrega de ciertos documentos que no se habían hallado entre los entregados por el Cardenal. Negando éste tener en su poder el documento requerido, fue nuevamente conminado a su entrega inmediata y habiendo vuelto a rehusar, se dispuso finalmente el registro de los cajones que conformaban su equipaje, localizándose entre los mismos — según refirió después el mismo Grimaldo- el ansiado documento ${ }^{82}$.

El documento que, al parecer, tanto interés tenía para el monarca y para el propio Alberoni -dispuesto a negar su existencia incluso ante la realidad de haber sido hallado entre sus papeles - era, según se indicó reiteradamente al Ministro caído, un codicilo al testamento que Felipe V había dictado en El Escorial el 25 de octubre de I7I7. Entre los papeles del Cardenal se conserva efectivamente un documento de esa fecha, escrito por la mano temblorosa del Rey, que fue publicado hace algunos años por BADORREY, en cuya vista ésta no dudó en afirmar que Alberoni había recibido «si no el título, sí las facultades de un primer Ministro» ${ }^{{ }_{3}^{3}}$. Un documento — sobre el que volveré después al tratar de los poderes conferidos a Alberoni-, que DE CASTRO ha identificado con el codicilo del testamento de Felipe V que insistentemente fue reclamado a Alberoni en los días que siguieron a su caída en desgracia ${ }^{84}$.

79 Las noticias ofrecidas por SAN FELIPE, Comentarios, cit., pág. 3I9 y G. COXE, España bajo el Reinado de la Casa de Borbón, cit., II, pág. I7I, difieren un tanto. El primero afirma que fue visitado tan sólo por Ministros extranjeros, en tanto Coxe señala que fue recibió el homenaje de muchos más de los que lo habían tratado cuando aún gozaba del favor real.

80 «... se ha servido su Mag. apartar al señor Cardenal Alberoni de los negocios en que intervenia, dando, al mismo tiempo, sus Reales ordenes para que, saliendo luego de estos Dominios, se pueda restituir a Italia», Gaceta de Madrid, del I2 de diciembre de I7I9.

8I El incidente lo refiere el propio Alberoni en las memorias de su persecución. Según L. TAXONERA, El Cardenal Alberoni, cit., págs. 237-238, el asalto acabó con la vida de dos de los integrantes del séquito de Alberoni y el saqueo de sus pertenencias.

82 La correspondencia cruzada entre Grimaldo y Alberoni se conserva en AHN, Estado, 2884/I. El Inventario de los cajones, cofres y otras cosas de que se compone el equipaje del Cardenal Alberoni, en ibídem, 8753. Las órdenes dirigidas a diversas autoridades y a los encargados de proceder al registro, en ibídem, $2884 / 3$.

83 El documento puede verse en AHN, Estado, 2884/2. Fue publicado, con leves diferencias, por B. BADOR, Los orígenes, cit., pág. 40 y, más adelante, por D. PERONA, Los orígenes, cit., pág. I53 y “Apuntes sobre el perfil institucional de Alberoni, Riperdá y Godoy", en AHDE, 68 (I998), págs, 83-I50.

84 A la sombra de Felipe V, cit., pág. 333. 
Las noticias acerca del «codicilo» son escasas y acaso poco esclarecedoras. Por una parte, son varias las referencias a que Felipe V habría testado en El Escorial, en octubre de I7I7. Lo dice el Marqués de Grimaldo en diciembre de I7I9, cuando reclama a Alberoni la entrega de los documentos requeridos por el Rey ${ }^{85}$. Lo apunta también BAUDRILLART, quien informa de la alarma generada en la Corte francesa cuando se conocieron - a través de Saint-Aignan, su agente en Madrid - la gravedad de la enfermedad del Rey Católico y el posible sentido de sus disposiciones testamentarias ${ }^{86}$. Confirma finalmente la existencia del citado testamento el propio Alberoni, quien en noviembre de I7I7 se refiere al mismo en una de sus cartas al Conde Rocca ${ }^{87}$. El mismo Alberoni ofrece dos años después un dato más, la identidad del escribano ante el que se había otorgado —al que se refiere como Merli-, admitiendo quizá también haber tenido en su poder hasta entonces una copia del citado testamento y haberlo entregado ya al monarca ${ }^{88}$.

Un documento conservado entre los reunidos por Grimaldo con ocasión de la formación de la causa contra Alberoni en I720, indica asimismo la fecha en que habría sido otorgado el testamento, el 26 de octubre de I7I7, en la que efectivamente los Reyes se encontraban en El Escorial y en la que el Rey atravesaba una fuerte crisis, un agravamiento de su enfermedad ${ }^{89}$. Ese mismo documento vincula además en cierto modo el testamento y el poder extraordinario conferido a Alberoni en esa misma fecha - al que me he referido antes - señalando que el mismo «está escrito de mano propia de S.M. que firmó, $y$ después de su propia mano testó». Por otra parte, el poder —que se conserva original entre la documentación de Alberoni conservada en la sección de Estado del Archivo Histórico Nacional- parece responder así a la recomendación que, según indica SAN FELIPE ${ }^{9 \circ}$, le habían hecho al Rey sus médicos de que se apartase absolutamente de los negocios más graves, motivo por el que Felipe $\mathrm{V}$ resolvió dejarlos en manos de Alberoni.

¿Era, pues, éste el documento que Felipe $V$ insistía en recuperar dos años más tarde? A juzgar por lo afirmado por el Marqués de Grimaldo, se trataría sin duda de dos documentos diferentes. Lo que se reclama a Alberoni para que lo entregue es un codicilo al testamento del Rey, de cuyo contenido no se ofrece ninguna noticia. Sin embargo, es indudable que su contenido preocupa al monarca, que insiste hasta tres veces en requerir a Alberoni su devolución. Parece claro que el motivo de la preocupación no puede ser el que Alberoni pueda servirse del mismo en algún modo, pues, como le recuerda expresamente Grimaldo «así el referido papel como el testamento no tienen ni tendrán en ningún tiempo el menor uso, fuerza ni validación mediante las providencias que a este fin tienen dadas sus magestades» ${ }^{9 \mathrm{I}}$.

85 AHN, Estado, 2884/I, Grimaldo a Alberoni, Madrid, I8 de diciembre de I7I9.

86 Philippe V, cit., II, pág. 249.

87 «l Re, grazie a Dio, sta meglio. Le due notti passate ha dormito sette hore continue cadauna. Mangio con buono appetito ed è assai gioviale. Dopo che fece il suo testamento martedi pasato, il mondo l'haveva creduto all'agonia; però hormai sono disingannati; era un pezzo che nutriva questa voglila, e, senza una valida opposizione che gli è stata fatta, l'havrebbe fatto quattro mesi sono» Alberoni a Rocca, I de noviembre de I7I7, en E. BOURGEOIS, Lettres intimes, cit., CCCCLXXXVIII, págs. 558-559.

88 No resulta clara la afirmación de Alberoni al respecto. Dice «he recibido la carta de V.S. en fecha de I 8 del corriente, que me ha entregado el Marqués de Cayrles, en la cual me dice que habiendo yo restituido a $\mathrm{Su}$ magestad el testamento que hizo el año I7I7 no haya restituido el codicilo o codicilos que Su majestad hizo después. Puedo asegurar a Su majestad en fe de sacerdote y con palabra de honor que nunca he tenido en mis manos tales codicilos, ni tampoco me acuerdo que $\mathrm{Su}$ majestad los haya hecho...», Alberoni a Grimaldo, Zaragoza, 20 de diciembre de I7I9, en AHN, Estado, 2884/I.

89 AHN, Estado, 2884/2.

90 Comentarios, cit., pág. 269.

9I Grimaldo a Alberoni, Madrid, 22 de diciembre de I7I9, en AHN, Estado, 2884/ı.

El mismo Grimaldo informa al por esas fechas que así se lo ha confirmado la oportuna consulta realizada al respecto: «Señor. Hauiendo venido aquí esta noche, de Aranjuez, Manuel Merlo, el escriuano que fue del 
Lo que preocupa, por tanto, al Rey es que trascienda, aunque sea dos años tarde, el contenido del mencionado codicilo, que, según se desprende de lo señalado por Grimaldo, se habría otorgado unos días más tarde que el testamento ${ }^{92}$. El buscado codicilo habría sido redactado no antes del 29 de octubre en que los Reyes abandonaron El Escorial regresando a Madrid y, en todo caso, antes de mediados del mes siguiente en que, según las noticias de la Gaceta de Madrid, el Rey se encontraba ya completamente recuperado de su dolencia ${ }^{93}$.

Es probable que el contenido del codicilo tuviera algo que ver con la organización de un Consejo de Regencia del que habría formado parte, en su caso, Alberoni, tal como el embajador francés había comunicado a su Corte. BAUDRILLART refiere que había llegado a encontrarse el Rey tan gravemente enfermo, que temiendo él mismo por su vida, resolvió hacer testamento, instituyendo una Regencia que gobernaría durante la menor edad de su primogénito. Añade que nadie dudaba entonces que la habría confiado a la Reina, con el Cardenal Alberoni como primer Ministro ${ }^{94}$. La gravedad de la situación por la que atravesaba el Rey Católico no había escapado a la atenta mirada de los Ministros de las Cortes extranjeras representadas en Madrid, que como Saint-Aignan o el inglés Doddington hablaban ya del comienzo de las intrigas para evitar un posible gobierno dominado por Alberoni ${ }^{95}$.

Como ha apuntado LYNCH, el año I7I8 estuvo plagado de conspiraciones. La posibilidad de un gobierno de Regencia del que habrían sido excluidos nuevamente los grandes, prendió la llama alentada desde Francia, fortaleciéndose el conocido partido español y formándose otros grupos como la conocida Junta chica cuyo objetivo exclusivo era acabar con el gobierno de Alberoni ${ }^{96}$.

El codicilo, que finalmente se recuperó — siempre según lo afirmado por el propio Grimaldo- de entre los papeles de Alberoni, no se conserva sin embargo entre éstos, ni fue remitido tampoco junto con el resto de la documentación reunida para la causa seguida en Roma a Alberoni tras su caída. Sí se hizo constar, sin embargo, por expreso mandamiento del monarca, la declaración del Marqués de Grimaldo afirmando haber conseguido

Escorial, y preguntándole lo que Vmag me mandó supiese de él, dize que el testamento no se protocoló, ni se haze nunca de los testamentos zerrados, que solo dejó en sus libros vna nota del otorgamiento, no por ser nezesaria, sino por la singular honrra y sin exemplar que logró en el acto de otorgarle, que copias ni sauiduría de él no la tubo, ni la deuia tener, ni supo lo que contenía; que cobdicilo no le vió, ni se otorgó ante él. Por otra vía, y con disimulo he sauido que ningún testamento, ni cobdicilo, se anula ni se puede anular, sino con la execución de otro en el qual por su naturaleza y por lo que preuienen las leyes, se anula y queda anulado qualquiera otro assi cobdicilo como testamento que anteriormense se aya hecho. Es todo lo mismo que yo tenia entendido y hize anoche presente a V.mag. », ibídem, 2884/3, Nota de Grimaldo al , sin fecha.

92 «El citado papel que se reduce (llámese o no se llama codicilo o codicilos, porque esto es cuestión de nombre) a uno que después de otorgado el testamento en El Escorial, le hizo V.Em ${ }^{\mathbf{a}}$ hacer a Su Magestad y aun escribir de su misma real mano, estando ya en Madrid, y todavía enfermo, en la Sala de los Espejos, donde Sus Magestades dormían entonces de que no solamente hace memoria él , pero lo tiene muy presente la Reina con todas las particularidades que concurrieron para la formación del citado papel y una cierta seguridad de que le recogió V.Em ${ }^{a}$ para ponerle y tenerle junto con el testamento, como también la tienen de que del referido testamento recogio V.Ema y quedo en sus manos un duplicado u copia del que también quiere Su Magestad recoger y que V.Em ${ }^{a}$ le remita con el otro que se le ha pedido y vuelve a pedir ahora», Grimaldo a Alberoni, Madrid, 22 de diciembre de I7I9, en AHN, Estado, 2884/I.

93 Gaceta de Madrid del 2 y del I6 de noviembre de I7I7.

94 Philippe V, cit., pág. 249.b

95 G. COXE, España bajo el Reinado de la Casa de Borbón, cit., II, págs. 22I-222.

96 A. BAUDRILlART, Philippe V, cit., II, págs. 249-256; G. COXE, España bajo el Reinado e la Casa de Borbón, cit. II, págs. 222-223; H. KAMEN, Felipe V, cit., págs. I54-I56. 
arrebatarle ese documento a Alberoni de resultas del registro al que se sometió su equipaje en Alicante y Cataluña ${ }^{97}$.

\subsection{Arresto y procesamiento de Alberoni}

El Cardenal Alberoni salió de Madrid el I2 de diciembre. Cuatro días más tarde, se comunicaba al Marqués de Caylus, comandante general del Reino de Aragón, que procediese a recoger, con la mayor reserva posible, cualquier carta que Alberoni escribiese desde Zaragoza «a Madrid u otra qualquiera parte de dentro o fuera de España» ${ }^{98}$. Idéntica orden se giró asimismo al príncipe Pío y a don Antonio Marun, por lo que tocaba a Barcelona y Gerona, respectivamente, indicándoseles, como a Caylus, que procediesen, en su caso, a remitir a Su Majestad, «cerradas», las cartas que se recogiesen. La persecución contra Alberoni acababa de empezar. Como antes se vio, su comitiva fue detenida primero y asaltada más tarde, pese a lo cual Alberoni consiguió alcanzar la frontera y prosiguió su viaje por el sur de Francia, bajo la atenta vigilancia de la comitiva que le proporcionó el Duque de Orleans, embarcando finalmente en Antibes con destino a Génova. Días más tarde, Alberoni tocaba puerto en Sestri, donde fue recibido con la noticia de que el Duque de Parma no le permitiría entrar en sus dominios. Resuelto a proseguir su camino hasta Roma, conoció también que el Papa no le recibiría, estando resuelto Clemente XI a formar proceso a Alberoni a instancia del Rey Católico, empeñado ciertamente en la persecución de quien había sido su Privado y secundado asimismo por el Duque de Parma ${ }^{99}$. El Papa resolvió solicitar a la República de Génova el arresto de Alberoni. Todo el empeño en adelante será presionar a los genoveses para que no permitieran a Alberoni escapar de su prisión $^{\text {10o }}$. Por su parte, el Duque de Parma aparecía especialmente interesado en recuperar la documentación que Alberoni pudiese conservar en su poder relativa al Ducado, para lo que estrechaba al Marqués de San Felipe, representante de Felipe V en Génova, a fin de que tratase de recuperarla. San Felipe, por su parte, ofrecía al Rey información detallada sobre la situación en la que se encontraba Giulio Alberoni:

«El Cardenal cree le viene el golpe de España; esso no lo sé, sé q es de la congregación de la Inquisición, el cardenal Iuidice, que no es su amigo, y si le puede meter en ella, no perderá diligencia, ni el Papa obra en esto sin algún sauor, porque Alberoni se há puesto mal con todo este mundo, $y$ temo que con el otro. Los amigos que aquí tiene son pocos. Y no le pueden valer, son mas sus enemigos y se le acrecentará el numero, si llegan a persuadirse que há caido de ueras de la gracia del Rey. En este arresto nadie le habla, pero como le dejan escribir es lo propio. Mucho se há ahogado de esta nouedad: está en la cama, dice que con dolor de cabeza. Un inglés de buena parte, que dicen ser Milord, ha estado con él estos dias quatro veces antes del arresto tambien há estado con él un Ingeniero nrô frances q servira en Cicilza, le conocia en Madrid, y era espia de su eminencia, aun lo es, pero conocida no hace mal, supongo q lo hará por el uil interes de cuatro reales: el cardenal tiene mas altas espias, pero con todo no se han atreudio a reuelar el secreto, pues

97 «.. puedo decir y a segurar a V.S.I. que habiendo resuelto S.M. resentido de esta negativa recoger y arrestar los papeles que llevaba el cardenal, como de hecho se ejecutó, en Cathaluña, se encontró luego entre ellos el referido codicilo original que se le habia pedido y el habia negado en fe de sacerdote y con palabra de honor, el cual puse yo en manos de S.M. de cuya expresa orden lo pongo en noticia de V.S.I.», Grimaldo al inquisidor general, San Lorenzo, 22 de julio de I720, en AHN, Estado, 2884/I.

98 Ibídem, 2884/3, Madrid, i6 de diciembre de I7ı9, el Marqués de Grimaldo al Marqués de Caylus.

99 L. TAXONERA, El Cardenal Alberoni, cit., pág. 242 y A. ARATA, Il processo, cit., pág. I6. En AHN, Estado, 2884/3, puede verse el comunicado dirigido al papa, el if de marzo de 1729 , para que asegure y tenga en toda custodia al cardenal Alberoni.

Io० Ibídem, Madrid, I9 de marzo de I720, A la República de Génova para se tenga a disposición del Papa al cardenal Alberoni. En el mismo puede consultarse también la correspondencia cruzada en los días siguientes con el Marqués de San Felipe, embajador de España en Génova, relativa al arresto de Alberoni. 
es cierto que tuvieron 24 oras de tiempo, $y$ huuiera escapado si lo huuiera sauido, mas yo no se adonde, sino se metía en los esquízaros, en los cantones herejes» ${ }^{101}$.

La principal preocupación consistía, sin duda, en evitar que Alberoni pudiera ser acogido en los dominios del emperador, para lo que se solicitaba la mediación del regente realizando las pertinentes instancias ante el emperador ${ }^{\text {102 }}$. De todo lo que se iba actuando se informaba puntualmente al Cardenal Aquaviva, con el fin de que continuase instando al Papa para que se mantuviese firme en su decisión de proceder contra Alberoni, presionando al tiempo a los genoveses, a través de San Felipe, para que pusiesen al Cardenal a disposición de $\operatorname{Roma}^{\mathrm{To}}$. Simultáneamente, Felipe V reiteraba al Papa su satisfacción por el arresto de Alberoni, al tiempo que se congratula a también de que se le hubiere impedido consagrarse Obispo de Málaga y del despacho de las bulas del Arzobispado de Sevilla en el Obispo de Osma.

«Por uno y otro doy a V.Sdad reverentes gracias como igualmente por la resolución reiteraba el Rey en abril de I720- de haber hecho arrestar la persona del referido Cardenal, de cuyas operaciones $y$ costumbres el tiempo que ha residido en mi Corte se hará V.B. enterar por medio de la relación informativa de los hechos que se han podido aclarar, que se expresará a continuacion de esta carta, a que espero dará toda aquella fe $y$ crédito que podrá justificarse cuando por V.Bd. se mandaren averiguar judicialmente, $y$ solicitando la bendición de V.Santidad le aseguro de mi filial respeto a su persona» ${ }^{104}$.

En efecto, se remitió a Roma un papel informativo en el que se explicitaban los cargos que se entendían probados contra Alberoni ${ }^{105}$. Clemente XI, a la vista de los mismos, resolvió comisionar al inquisidor general y Obispo de Barcelona para que efectuase las averiguaciones precisas. Habiéndose consultado con el padre Daubenton, confesor del Rey, se resolvió hacer entrega al inquisidor general de la abundante documentación y las numerosas testificaciones recabadas y que podían refrendar lo señalado en el escrito informativo ${ }^{\text {Io6 }}$.

IoIIbídem, carta de San Felipe, probablemente a Grimaldo, incompleta y sin fecha.

IO2 «Madrid, 3 de marzo de I72I, a D. Patricio Laules, ordenándole solicite que S.A.R. haga instancias al Emperador para que no dé asistencia alguna al cardenal Alberoni; Madrid, 4 de abril de I720, al abad Dubois, expreando la gratitud de S.Mag. por los empeños contraídos por el Sr. Duque Regente en los negocios de la prisión del Cardenal Alberoni y restitución de Gibraltar, para que lo manifieste así a S.A.R.», ibídem, 2884/3.

I03 Madrid, 9 de abril de I720, al cardenal Aquaviva, informándole de las resoluciones tomadas en París en orden a la prisión del cardenal Alberoni y de lo que aquí se manda a San Phelipe para que, en inteligencia de ello, continúe en instar a Su Santidad para que se mantenga en las más fuertes deliveraciones, ibídem.

IO4 La minuta de esta carta del de España al papa fue revisada por su confesor, el padre Daubenton, quien asimismo dio más adelante el visto bueno a la remisión de cierta documentación comprobante de los hechos imputados a Alberoni. La carta, fechada en Madrid el I8 de abril de I720, en ibídem, 2884/I.

I05 El Papel informativo para el Papa sobre las operaciones y costumbres del Cardenal Alberony, así como la documentación reunida por Grimaldo en los primeros meses de 1720 , en AHN, Estado, 2884. El citado papel informativo se localiza en la caja 3.

Io6 A instancia del propio inquisidor general, quien lo había sugerido así al confesor del, Felipe V le confirió, en el mes de julio de I720, toda la autoridad precisa para instar a los tribunales y Ministros a hacer entrega de los documentos que conservaren en sus oficinas y a prestar declaración ante el inquisidor general. La carta del inquisidor general a Daubentón, de iو de julio de i720, en ibídem, 2884/I. En las semanas siguientes Fueron interrogados los antiguos Secretarios de Alberoni, sus más estrechos colaboradores, los Secretarios del Despacho y cuantos otros Ministros o particulares se consideró que podían aportar algún dato de interés a la causa. 
El Rey parecía tener muy claro qué hacer para ir avanzando en la causa ${ }^{\mathrm{r} 7}$, pero entretanto el Senado de la República de Génova habría resuelto dejar libre a Alberoni, exigiéndole que abandonase a la mayor brevedad posible su territorio. A partir de ese momento, consiguió esfumarse, permaneciendo en paradero desconocido hasta que, en marzo de I72I, la muerte de Clemente XI le proporcionó la excusa de volver a Roma para participar en el cónclave que habría de elegir al nuevo Papa ${ }^{\text {108 }}$. De nada sirvieron los esfuerzos realizados por Felipe V, quien había hecho seguir a Alberoni desde comienzos de febrero de $172 \mathrm{O}^{\mathrm{Io9}}$. Finalizado el cónclave, el nuevo pontífice, Inocencio XIII fue dando largas al proceso, lo que inquietaba enormemente al Rey de España, quien a través del Cardenal Aquaviva trataba de tener información sobre el estado del proceso ${ }^{\text {II0 }}$. En I723, algunos intermediarios se dirigían al Rey tratando de obtener un cambio en su posición de fuerza en relación a Alberonir ${ }^{\text {III }}$. Unos meses más tarde, el Papa decidía confirmarle el Capelo de Cardenal. El mismo Alberoni lo comunicaba a Felipe V, habiéndose confeccionado una minuta para la respuesta en los siguientes términos, en enero de I724:

«Mui Reuerendo en Xpto. Padre Cardenal Alberoni, mi muy caro y muy amado amigo: Me han sido gratas las atentas expresiones que encuentro en vuestra Carta de 18 de diziembre del año proximo pasado, y no menos gustosa la noticia que en ella me daís del ánimo en que quedaua S.Santidad de poneros el Capelo Cardenalicio, y os estimo la atención que haueis tenido en participarmelo. Y podeis estar cierto que asi como en otro tiempo merecisteis mi confianza, $y$ mi gratitud, asi en adelante hallareis siempre mi animo propenso a atenderos, $\gamma$ que esto sera asi a proporcion de lo que por vuestra parte promoviereis, $y$ os interesareis en mis negocios $y$ en los de el Rey mi hijo en esa Corte, como lo decis en vuestra citada Carta, y como yo me lo prometo de las obligaciones en que estais constituido». remitirse ${ }^{\mathrm{II} 2}$.

La carta, cuyo texto aparece parcialmente tachado en la minuta, no debió llegar a

IO7 «Lo que hace falta por ahora para esta dependencia es lo siguiente: I $^{\mathbf{0}}$. Que se llame al Secretario del cardenal que está en Cádiz. $2^{\circ}$. Que también se llame al otro que está en Espinosa de los Monteros. $3^{\circ}$. Que se le pregunte a Patiño el tiempo y día en que le comunicó el cardenal la empresa de Cerdeña. Y la correspondencia con Ragozsi. Y asimismo las blasfemias que le oyó estando colérico, especialmente los desprecios contra la persona del papa y que remita las cartas que tuvo del cardenal hasta que se fue, o copia de ellas, y sobre todo importaría mucho que este sujeto fuera examinado aquí, pues no habrá otro que tanto pueda decir hacia estos hechos, y acaso puede conducir a otros importantes del servicio del, por razón de las cartas que tiene del cardenal, las cuales se las mando quemar, según me dijo delante de D. Rodrigo Caballero, pero el no quiso quemarlas, todo lo demas que se ha remitido está bien ordenado y se irá trabajando, etc. $4^{\circ}$. Que se vean los decretos remitidos al Consejo sobre las cosas de Roma para sacar de ellos los que conducen a este intento», ibídem.

Io8 F.M. TALIANI, El Cardenal Alberoni, p. 37-38.

Io9 La comisión a Ms. Lanchin, a través del cardenal Aquaviva, y los diarios enviados por aquél dando cuenta de las pesquisas realizadas, en AHN, Estado, 2884/3, donde se conserva también la abundante correspondencia cruzada con el gobernador de Longon a quien se encomendó expresamente tratar de obtener la nueva prisión de Alberoni a partir del mes de octubre de I720.

IIo Carta de Aquaviva a Grimaldo, 4 de abril de I722, en la que reitera lo ya manifestado en la semana anterior, en el sentido de que no parecía que la expedición de la causa fuese tan inminente, ibídem.

III Sobre el particular, véase la carta de Grimaldo a Daubenton, Balsaín, I4 de julio de I723, señalando que el había dispuesto que se diese traslado al confesor de la carta del abad Juan Bautista Bielato, fechada en Génova, el 29 de junio, en la que imploraba la piedad de Su Majestad para con Alberoni, permitiéndole vivir en paz en Roma, con los honores correspondientes a un cardenal, ibídem.

II2 Esto explica que, seis meses después, Alberoni escribiese a Grimaldo trasladándole el consuelo que había supuesto obtener respuesta del a una de las muchas cartas que Alberoni le dirigía interesándose por su estado de salud y sus asuntos. Esta y el resto de la correspondencia entre Alberoni y Grimaldo, en ibídem. Una valoración de las mismas, en C. de CASTRO, A la sombra de Felipe V, cit., págs. 352 y ss. 


\section{Alberoni y el gobierno de la Monarquía española}

Del papel desempeñado por Giulio Alberoni en relación al gobierno de la Monarquía española, se han destacado, entre otros aspectos, su intervención directa en el desarrollo de ciertas negociaciones diplomáticas, en particular, la responsabilidad en el cambio de rumbo impreso a las relaciones con la Santa Sede, su participación en los relevos producidos al frente de las Secretarías del Despacho a comienzos de I7I5 y su decidida apuesta, dos años más tarde, por la vía reservada, que, en la práctica, relegó tanto a Consejos como a Secretarios del Despacho, colocando bajo control directo de Alberoni la práctica totalidad de los negocios públicos.

Sin embargo, las noticias acerca de su gestión política son, por lo general, poco concretas. Coincidiéndose por todos en el enorme poder alcanzado por Alberoni y en el control que ejerció sobre todos los negocios, se afirma que era, sin duda, el personaje más relevante de la Corte, que gozaba de una gran autoridad, o que ejerció un gobierno despótico, un poder exclusivo y absoluto. «Gigante autoridad» es la expresión utilizada por el Marqués de SAN FELIPE para describir la posición de Alberoni. SAINT SIMÓN le atribuye las reformas acometidas en I7I7, que, en efecto, pusieron todo el gobierno bajo su control. BAUDRILLART recuerda que logró apartar a todos, acaparando la confianza del Rey, o -en palabras de COXE- «usurpando a los Ministros la discusión de los negocios públicos». Por su parte, DESDEVISES lo tilda de revolucionario, al tiempo que recuerda su carácter emprendedor y se refiere al triunfo que alcanzó sobre los Consejos en los que se asentaba la alta nobleza española, lo que le lleva a afirmar que Alberoni habría supuesto una turbulencia que obligó a España a ponerse en movimiento ${ }^{\mathrm{rn}}$.

No cabe duda de que, a partir de la celebración del nuevo matrimonio real, Alberoni afianzó definitivamente su posición en la Corte. A partir de ese momento -según ha apuntado ESCUDERO- Alberoni habría gobernado efectivamente España, de suerte que tras su caída en desgracia, cuatro años después, se habría dejado sentir un «hondo vacío» motivado por la salida de escena «de quien había anulado el funcionamiento de los organismos que podían oscurecer su poder absoluto» ${ }^{\text {II4 }}$.

Alberoni desempeñó, qué duda cabe, un papel preponderante entre I7I5 y I7I9, de suerte que la cuestión principal estriba en determinar cómo pudo hacerlo, cual era, en definitiva, su posición institucional en el entramado de la Monarquía. De la caracterización institucional de Alberoni se ocupó hace una década Dionisio PERONA, para quien resultaba clara su condición de primer Ministro de Felipe V desde I7I7, al modo de los Validoss con los que habían gobernado los Austrias, toda vez que se habría constituido en el único favorito, acaparando la confianza del monarca, apartando de éste a los restantes Ministros y mostrándose públicamente ante todos como el depositario de la confianza del monarca $^{\text {II5 }}$. De este modo, Alberoni parecía encajar en el molde correspondiente al Valimiento construido por TOMÁS Y VALIENTE, quien en una sólida exposición de conjunto destacó el carácter no reglado de esta institución, señalando que presenta unos contornos difusos, siendo así apreciables diferencias muy considerables de unos a otros Validos en función del contexto en el que se producía el Valimiento y de la personalidad de sus protagonistas ${ }^{\mathrm{II} 6}$. La realidad extrainstitucional del Valimiento -en expresión reciente de ESCUDERO $^{\text {II7 }}$ - a lo largo de prácticamente todo el siglo XVII, estuvo presente asimismo en otras Monarquías, constituyendo un fenómeno europeo de larga duración, tal como apuntó

II3 La España del Antiguo Régimen, cit., págs. 268-272.

II4 Los orígenes del Consejo de Ministros, cit., I, págs. 54-58.

II5 «Apuntes sobre el perfil institucional de Alberoni, Riperdá y Godoy», cit., págs. IIo-III.

II6 Los Validoss en la monarquía española del siglo XVII, Madrid, I982..

II7 «Privados, Validoss y Primeros Ministros». Estudio introductorio de Los Validoss, Madrid, 2004, del que es editor J.A. ESCUDERO. 
BERENGUER $^{\text {II8 }}$ en un sugerente análisis que constituyó el punto de partida de los realizados más recientemente, bajo el atractivo título de El mundo de los Validos, coordinados por John ELLIOT y Laurence BROCKLISS ${ }^{\text {II }}$. A estos trabajos han seguido hace apenas un lustro los estudios particulares de algunos de los Validos de los Austrias, siendo de destacar aquí el que se ha traspasado sobradamente el marco temporal del siglo XVII, contemplando el fenómeno del Valimiento en el contexto del siglo XVIII, con referencias concretas a la consideración como tales de personajes tan dispares entre sí como Riperdá, Godoy o Alberoni ${ }^{\text {I20 }}$.

Para TOMÁS Y VALIENTE era la dimensión pública de la actuación del Privado o favorito, esto es, la evidencia de su intervención directa en el gobierno, lo que permitía trazar la línea que separaba al Validos del resto de los Privados de los Reyes ${ }^{\mathrm{I2I}}$. Ciertamente, como ha recordado ESCUDERO ${ }^{\mathrm{12} 2}$, Privados y Validos comparten la confianza del monarca y desempeñan un papel más o menos relevante en el manejo de ciertos asuntos públicos, de suerte que la diferencia esencial entre ambos estribaría además en el monopolio de la confianza del monarca que es capaz de asegurarse el Validos, quien, a diferencia de otro tipo de Ministros, no comparte su posición de privilegio con ninguno, acaparando para sí la atención del Rey y haciendo ostensible su capacidad de influir sobre el monarca.

Alberoni actuó -en palabras de SAN FELIPE ${ }^{123}$ - sin título de primer Ministro, pero «con permisiones de serlo». O lo que es lo mismo, intervino en todo y fue seguido por todos como si el monarca mismo le hubiese atribuido poderes para tomar parte decisiva en todos los negocios públicos. ¿Se los atribuyó en algún momento? Creo que no. Más allá de algún apoderamiento concreto, en los primeros años, para la conclusión de un determinado negocio, no parece que Alberoni hubiere recibido nombramiento o comisión alguna en los cinco años en que se mantuvo en la confianza de los Reyes de España.

El habitualmente conocido como «quinquenio Alberoni» constituye, en todo caso, a mi modo de ver, un período complejo en el que pueden, por lo que al predominio de Alberoni se refiere, destacarse dos etapas. Una primera en la que el abate Alberoni, favorito de la Reina Isabel de Farnesio, se abre decididamente paso en el inexistente «gabinete» del Rey. Un tiempo en el que el núcleo de decisión política —el antaño gabinete o despachose ve reducido en este tiempo al Rey, la Reina y los Ministros con los que despachan individualmente, e incorpora quizá a Alberoni — destacado consejero e inicial mentor de Isabel de Farnesio-, en cuya presencia se abordan muchos de los negocios. Pero Alberoni no es en este tiempo el único que goza de la gracia del monarca, sino uno de los Ministros escogidos, muy aventajado ciertamente, al que se encomienda el tratamiento de ciertos asuntos que Alberoni maneja con habilidad oficiosamente.

El comienzo de la segunda etapa vendría marcado así por la salida de la escena política de los otros Ministros aún próximos al Rey. El punto de partida es, pues, la caída del Cardenal Giudice, que acercó mucho a Alberoni al monopolio de la confianza del Rey. Restaba únicamente ir apartando al resto. Y Alberoni se dispuso a hacerlo en los siguientes meses. No recibió en este tiempo ningún encargo expreso por parte del monarca, no se despachó ningún nombramiento, pero su relevante papel en el gobierno fue desvelándose único a partir de la caída de Giudice, permitiéndole acometer una serie de reformas en el

II8 «Pour une enquête européene: le problème du ministériat au XVIIe siècle», en Annales, 29 (I974), págs. I66-I92.

II9 The World of the Favorite, Yale, I999.

I20 Junto a los trabajos ya citados, editados por J.A. ESCUDERO en la obra colectiva Los Validoss, es preciso mencionar la reciente publicación por C. MAQUEDA ABREU de un estudio relativo al cardenal Alberoni, cit.

I2I Los Validoss en la monarquía española del siglo XVII, cit., pág. 32.

I22 «Privados, Validos y Primeros Ministros», cit., págs. I7-33.

I23 Comentarios, cit., pág. 3I3. 
aparato de la administración central que colocaron definitivamente bajo su control, a la vista de todos, el gobierno de la Monarquía española.

La base del poder de Alberoni continuó siendo la privanza de los Reyes, su amistad y confianza con la Reina primero y después también con Felipe $V$, que le habían permitido intervenir en ciertos aspectos del gobierno, ejercitando unos poderes que no habían sido explícitamente otorgados en ningún momento, respondiendo únicamente a su privilegiada posición de hombre de confianza de los Reyes.

Como ocurriera con otros tantos relevantes personajes políticos que intervinieron en el gobierno merced a la confianza que en ellos habían depositado sus monarcas, la huella escrita del paso de Giulio Alberoni por la Administración española es ciertamente muy reducida. Bien sea porque Alberoni — como antes de él buena parte de los Privados de los últimos Austrias - prefirió el despacho oral, disponiendo verbalmente la mayor parte de las órdenes, bien porque se sirvió para ello de los Secretarios del Despacho, son escasos los documentos de carácter público firmados de la mano de Alberoni de los que resulté con claridad su intervención decisiva en la resolución de los negocios públicos. Las noticias son en todo caso más abundantes a partir de I7I7, en que están documentadas muchas de las órdenes dirigidas a los diferentes Ministros implicados en la dirección de la contienda bélica, a los que escribe directamente Alberoni, si bien frecuentemente les advierte de que se les han dirigido instrucciones más precisas o determinadas órdenes por mano de Miguel Fernández Durán, Secretario del Despacho de Guerra ${ }^{\mathrm{I} 24}$.

La principal fuente de información acerca de la actividad pública desarrollada por Alberoni en los primeros años serán, pues, las crónicas del reinado del primero de los Borbones españoles y la abundante correspondencia del Validos con su tierra de Parma: la oficial, dirigida al Duque Farnese, en muchas ocasiones cifrada y la más relajada y abundante relación epistolar con su amigo Ignazio Rocca, Ministro de Hacienda de Parma $^{\mathrm{T} 25}$. Junto a ésta, las cartas del enviado inglés Doddington a su Ministro Stanhope, o las dirigidas extraoficialmente por Alberoni a este último y a otros varios Ministros extranjeros, constituyen la base principal para el análisis de la intervención de Giulio Alberoni en el gobierno a partir del I7I $5^{\mathrm{I2}}$.

\section{Reformismo y contrarreformismo}

El cambio en la dirección del Gobierno de la Monarquía que trajo consigo la llegada de Isabel de Farnesio y el ascendiente que, de manera inmediata, logró sobre su esposo, se tradujo en una apariencia de "rompimiento" que daría lugar al desarrollo de un nuevo proyecto político.

«La cour d’Espagne -escribían desde Madrid al Ministro Torcy el 3I de diciembre de $\mathrm{I}_{\mathrm{I}} \mathrm{I}^{\mathrm{I27}}$ - est entièrement different de ce quèlle étoit il $y$ a dix tours. C'est une cour toute nouvelle et un Systeme tout nouveau».

I24 Sirva como ejemplo la abundante correspondencia entre Alberoni y don Blas de Loya, en los años I7I8 y I7I9, en AHN, Estado, 2884/I y $2884 / 2$.

I25 Las primeras se localizan en ASN, Farnese, fascio 53-54; la correspondencia con el Conde Rocca se conserva en el Archivo del Collegio Alberoni y fue editada por BOURGEOIS, Lettres intimes, cit.

I26 La correspondencia entre Alberoni y Bubb, después conocido como Doddington, se conserva, así como muchas otras de las cartas cruzadas con el representante español en Londres, Marqués de Monteleón y otros tantos personajes, en la British Library. Las cartas entre Doddington y Alberoni, custodiadas en Egerton, 2I702I75, las dio a conocer G. COXE en el vol. II de su España bajo el Reinado de la Casa de Borbón.

I27 Pachau a Torcy, 3I de diciembre de I7I4, en A. BAUDRILLART, Philippe V, cit., pág. 622. 
Unos cambios, que afectaron en primer término a los personajes más destacados del equipo anterior, y, después, también, a la estructura misma de la Administración. Contrarreforma, involución, retroceso en el proyecto reformista, son algunas de las expresiones utilizadas para caracterizar el denominado «quinquenio Alberoni». Unas reformas cuya responsabilidad se atribuye principalmente a este Ministro y en la que es preciso distinguir dos momentos. Uno primero, correspondiente al año I7I5, en el que se adoptaron una serie de medidas urgentes para atender la crisis que había supuesto la salida de Ursinos y con ella la de Orry, siendo éste último el eje sobre el que se había hecho pivotar el conjunto de la reforma implantada en dos tiempos entre I7I3 y I7I4. Unas reformas que bien pueden parecer un cierto paso atrás, pero que en todo caso están limitadas a uno sólo de los pilares del nuevo sistema de gobierno y que además apenas tuvieron tiempo de surtir efecto alguno. Un segundo momento -al que me referiré en el siguiente apartado- éste sí enteramente Alberoni, que en modo alguno puede entenderse contrarreformista, sino, bien al contrario, el paso decisivo para la consolidación del sistema proyectado por Jean Orry.

\section{I.I. Las reformas Ursinos-Orry}

Como es bien sabido, el cambio dinástico en el comienzo de i70o trajo consigo un proceso de reestructuración de la administración central con la que habían gobernado los Austrias. Las reformas que acompañaron a los primeros años del reinado de Felipe $\mathrm{V}$ no dieron muestras aparentes de ruptura con el sistema anterior, que, sin embargo, iba adaptándose a la que se pretendía una estructura de gobierno centralizada y, por ende, más ágil y eficaz ${ }^{\mathrm{I} 2}$. El nuevo monarca, instruido en la práctica de la administración central francesa $^{\mathrm{I} 29}$, se enfrentaba a la difícil tarea de gobernar sus dominios asistido por un único Secretario que servía de enlace entre el Rey y la compleja red de órganos colegiados desarrollada en los siglos XVI y XVII. Poco después de su llegada a España, siguiendo los minuciosos consejos recibidos de su abuelo el Rey Cristianísimo, amplío el número de sus colaboradores, evitando, como se le había aconsejado, depender de un único Ministro. El nuevo Despacho -expresión con la que comenzó a ser conocido el grupo más o menos numeroso de asesores del Rey- estuvo integrado inicialmente tan sólo por españoles, de suerte que parecía un trasunto de la Junta asesora que había acompañado los últimos días de Carlos II. No presentaba una planta fija y registró efímeras ampliaciones y un drástico reajuste, en el comienzo de I703, en el que el Despacho se redujo a la entrevista del Rey con el Secretario Ubilla. Comenzó a partir de entonces una nueva etapa marcada por el que ESCUDERO ha designado como sector no oficialista francés, representado por la Princesa de los Ursinos y sus protegidos, algunos de los cuales fueron introduciéndose en el Despacho, iniciándose una tímida reforma en la que Ubilla, alcanzado por el desafecto del cada vez más poderoso eje Ursinos-Orry ${ }^{130}$, hubo de ceder algunas de sus competencias a favor del Marqués de Canales, a quien se encomendó el despacho de los negocios de la Guerra. El trasfondo del conflicto sucesorio marcó decisivamente la puesta en marcha de las medidas reformistas, de suerte que si decidió el alcance de la primera especialización del Despacho, arrastró asimismo consigo no sólo a Canales sino también a la Princesa de los Ursinos y a Orry, artífices de la fracasada reforma ${ }^{\mathrm{I3I}}$. El nuevo gabinete dominado por la

I28 Recientemente, L. M. GARCÍA-BADELL, "Los primeros pasos de Felipe V en Españ: Los deseos, los recelos y las primeras tensiones", en Cuadernos de Historia del Derecho, I5 (2008), págs. 45-I27, analiza, entre otras cuestiones, las primeras medidas de reforma de la estructura del gobierno.

I29 Una atinada síntesis del sistema francés -basado en la existencia de un Canciller, un Controlador general de finanzas y cuatro Secretarios de estado especializados en materias determinadas-, en R. GÓMEZ RIVERO, El Ministerio de Justicia en España (I7I4-I808), Madrid, I999, págs. 37-95.

I30 Jean Orry había llegado a España en I7or con el encargo expreso de procurar la reorganización de la maltrecha Hacienda de la Monarquía. Junto con Ana María de Tremouille, Princesa de los Ursinos, a la sazón camarera de la Reina María Luisa y el embajador francés Amelot, llevaron adelante un ambicioso proyecto de reforma del sistema de gobierno.

I3I A. BAUDRILLART, Philippe V, cit., pág. I86. 
política oficialista francesa se vio pronto envuelto, sin embargo, en nuevos conflictos internos que desembocaron en el relevo de Ubilla ${ }^{\mathrm{I3}}$. El cambio de titular en la Secretaría del Despacho -en el comienzo de I705 fue designado el Marqués de Mejorada- coincidió con el anuncio del regreso de la Princesa de los Ursinos, a la que acompañaron poco después el también retornado Jean Orry y el nuevo representante francés en la Corte española, Michel Jean Amelot, quienes encauzarán definitivamente la reforma del Despacho en el verano de $1705^{133}$.

Un Decreto de in de julio dispuso la primera división formal de la hasta entonces única Secretaría del Despacho en dos Departamentos: uno para todo lo tocante a Guerra y Hacienda y otro que debía ocuparse de los restantes asuntos de la Monarquía. La razón de ser de la falta de una mayor concreción la explicaba tiempo después Jean Orry, señalando que «se redujo a este número, sin explicar sus encargos $y$ incumbencias, por no atraher el odio de los Consejos, que estaban entonces en posesión de hacerlo todo, sin dejar al Rey más que la apariencia del gobierno» ${ }^{\mathrm{I} 4}$. El despacho de la Secretaría «de todo lo demás de cualquier materia que sea» quedó a cargo del Marqués de Mejorada, designándose para servir la Secretaría de Guerra y Hacienda a José de Grimaldo, quien, de hecho, se convertirá en los siguientes años, sin embargo, en el Ministro principal. Formalmente Grimaldo tenía atribuido el despacho de los negocios de Guerra y Hacienda, lo que no impidió que pasaran por su mano buena parte de los negocios que debía despachar el Marqués de Mejorada. La guerra y la urgente necesidad de obtener recursos con los que hacer frente a los enormes gastos que generaba, situaron a Grimaldo desde el comienzo en la primera línea de la política española del momento, en tanto el Marqués de Mejorada resultaba al margen del grupo encargado del gobierno, organizado entorno a Amelot, del que continuaban formando parte Ursinos y Orry y en el que fueron integrándose los nuevos responsables de los Consejos y, puntualmente, otros destacados personajes.

La salida de Amelot, en I709, puso fin a la presencia de los embajadores galos en el Consejo de Despacho, constituyendo el punto de inflexión en la influencia francesa sobre la política española y dándose paso a una remodelación del Consejo de Despacho en el que finalmente se franqueó la entrada a alguno de los más destacados antagonistas de la política francófila que había marcado el primer decenio del reinado ${ }^{135}$, en tanto permanecieron los dos Secretarios del Despacho -Grimaldo y Mejorada- en sus respectivos encargos. Entre I7Io y I7I4, el Consejo de Despacho fue remodelado de nuevo en varias ocasiones, de resultas de la creciente tensión existente en la Corte a medida que iban entrando en escena nuevos elementos que podían apartar de la voluntad del Rey a la Princesa de los Ursinos y a sus inmediatos protegidos ${ }^{136}$.

Las reformas de los órganos de las Administración central española estaban a punto de comenzar. A finales de I7I3 se había dado nueva planta a los diversos Consejos de la Monarquía, incrementando el número de sus miembros y dividiendo entre varios individuos la Presidencia de los Tribunales, lo que -según SAN FELIPE- lejos de contribuir al más rápido despacho de los negocios, lo embarazaba aún más ${ }^{137}$. El propio Consejo de

I32 Ibídem, págs. I82-I88, en las que pueden seguirse los cambios introducidos en el Despacho.

I33 Acerca de la sustitución del embajador francés, Duque de Grammont, véanse las Mémoires del duc de Noailles, cit., pág. 342 y SAN FELIPE, Comentarios, cit., pág. 84. En la designación de Amelot pesó, según C. de CASTRO, A la sombra de Felipe V, cit., pág. I25, la insistencia de la Princesa de los Ursinos, que logró que esta vez fuese designado un embajador de su confianza.

I34 AHN, Estado, 3497, Propuesta de un Consejo Real y Secretarios de Estado.

I35 Accedieron en este tiempo al Despacho el Marqués de Bedmar y el Duque de Medinaceli, a quien -según SAN FELIPE, Comentarios, cit., pág. I82- promocionó la Ursinos con la finalidad de ganarse a los españoles en un momento en el que, eliminado Amelot, crecía de manera imparable su pujanza en la Corte.

I36 En I7II se incorporó el Conde de Bergeyck y poco después lo hizo también el cardenal Giudice.

I37 Comentarios, cit., pág. 245. G. COXE, España bajo el Reinado de la Casa de Borbón, cit. II, págs. II7-II8, valora las reformas de manera bien distinta, señalando que, si bien, sin duda, debían producir inicialmente 
Despacho reflejaba ya también la tendencia a la especialización de los Ministros que se materializó después en el Real Decreto de 30 de noviembre de I7I4. Desde enero de ese año, el Despacho se reunía con el Rey seis días a la semana, tratándose en cada uno negocios diferentes ${ }^{138}$. Cada día asistían dos o tres de los miembros del Consejo y el Secretario del Despacho a quien correspondiese en atención a la materia a tratar. Acudían siempre, además, Orry y el Conde de Bergeyck, a los que se daba entrada a todas las sesiones $^{\mathrm{I} 39}$. A lo largo de la primera mitad de I7I4 el Consejo de Despacho fue reduciendo el número de sus miembros. El Marqués de Mejorada fue relevado por don Manuel de Vadillo y Velasco, de suerte que únicamente Grimaldo, que había gozado de la confianza de Felipe V y del favor de la Reina María Luisa, salió indemne de los sucesivos enfrentamientos en la Corte, fortalecido en la posición de Secretario principal que habría ostentado desde I705.

El 30 de noviembre de I7I4, un nuevo decreto venía a incrementar el número de las Secretarías del Despacho ${ }^{\mathrm{I} 40}$. La reforma-como ha señalado ESCUDERO ${ }^{\mathrm{I} 4 \mathrm{I}}$ - se presentó como un paso más en la configuración del régimen ministerial. Sobre la base de la planta resultante del Decreto de in de julio de I705, se llevó a efecto una nueva división, resultando un Departamento de Guerra, otro de Hacienda, otro de Indias y Marina, uno de Justicia y Negocios Eclesiásticos, y otro de Estado. Lejos de suponer una medida aislada o improvisada ${ }^{\mathrm{I} 42}$, el Decreto de 30 de noviembre de I7I4 respondió al proyecto global de reforma de la Administración española impulsado por los asesores franceses de Felipe $\mathrm{V}$ desde el comienzo de su reinado y programado, poco después, de manera pormenorizada por Jean Orry $^{\mathrm{T} 43}$. Las causas de la división del Despacho hay que buscarlas en la necesaria tendencia a la especialización que demandaba el nuevo gobierno. El objetivo último de la reforma aparecía claro: se pretendía lograr el mayor acierto en la resolución de los negocios y la prontitud necesaria en su tratamiento ${ }^{\mathrm{I} 44}$. La razón de la reforma radicaba, pues, en la necesidad de agilizar el funcionamiento de unos órganos de gobierno que, desde tiempo atrás, venían resultando ineficaces al haber sido superados sus medios por el volumen de asuntos a los que debían atender. El ensayo de división realizado en I705 había producido ya el resultado esperado — habiéndose agilizado en buena medida el ritmo administrativo, de manera que no se dudó en avanzar en esa línea de distribución de los negocios entre diversos órganos que, dotados de una mayor capacidad de gestión al centrar su atención tan sólo en materias concretas, y próximos al Rey, pudiesen proporcionar la agilidad que se

alguna confusión, «la división del consejo en secciones para la discusión de los negocios, los reglamentos más claros para el despacho, la abolición de infinitos días de vacaciones que atrasaban la administración de justicia y suspendían el curso de los negocios, eran sin disputa medidas no menos cuerdas que útiles».

I3 8 En este sentido, H. KAMEN, La Guerra de Sucesión en España, I700-I7I5, Barcelona, I974, pág. I22, se refiere a un Real decreto de 3I de enero de I7I4 y a la progresiva especialización del Despacho, como uno más de los pilares de la reforma trazada por Jean Orry.

I39 Ibídem. La noticia que ofrece al respecto SAN FELIPE, Comentarios, cit., pág. 245, es muy similar.

I40 El Real Decreto de 30 de noviembre de I7I4 en Nov. Rec., lib. III, tít. IV, ley VI.

I4I Los Secretarios de Estado y del Despacho, cit., I, pág. 30 I.

I42 Pareció entenderlo de este modo Fernando MURO ROMERO, "Instituciones de Gobierno y Sociedad en Indias (I700-I760)", en Estructuras, Gobierno y Agentes de la Administración en la América española (siglos XVI, XVII y XVIII). Trabajos del VI Congreso del Instituto Internacional de Historia del Derecho Indiano en Homenaje al Dr. Alfonso García Gallo, Valladolid, I984, p. I70, para quien se trataba de «improvisadas reformas que incluso llevaron a Luis XIV a manifestar a su nieto la dificultad que conllevaba tratar de extrapolar a España el aparato administrativo del Estado francés».

I43 En AHN, Estado, leg. 3497 consta un documento sin firma titulado Propuesta de un Consejo Real y Secretarios de Estado, publicado como tal texto anónimo por J.A. ESCUDERO, Los Secretarios de Estado y del Despacho,4 vols, Madrid, I969, IV, doc. 2I0, pp. I275-I283; La coincidencia prácticamente literal de éste con otro documento señalado por Jean Orry y titulado División de competencias entre los Secretarios del Despacho, conservado en el libro 696d, letra s, de la misma Sección del AHN, llevan a concluir sin duda la autoría del hacendista francés con respecto al primero.

I44 Así se expresa en un Informe anónimo acerca de la reforma del Despacho en el Reinado de Felipe V, que puede verse en AGS, Guerra Moderna, leg. 7301.bv 
pretendía. Se trataba, en definitiva, de descargar al Marqués de Grimaldo de buena parte de las negociaciones que, desde I705, corrían bajo su control, toda vez que el tímido reparto de competencias efectuado entonces se había visto después superado en la práctica por la presión de la escena política en la que se desarrolló. En un tiempo en el que del curso de la guerra dependían los demás resortes del Estado, la práctica totalidad de los asuntos corrían por la mano del titular de la Secretaría del Despacho de Guerra. Superada la crisis provocada por la Guerra de Sucesión, el siguiente paso debía avanzar en la misma línea, potenciando la posición de los Secretarios del Despacho frente a los Consejos, consolidando de este modo la tendencia a la especialización apuntada nueve años antes.

«No hay más que estos medios capaces de dar forma a la Administración de los negocios del Rey», decía Jean Orry en lo que puede entenderse como su «Plan General de reorganización del sistema administrativo» ${ }^{\mathrm{T} 45}$. La Propuesta de un Consejo Real y Secretarios de Estado elaborada por el asesor galo aparecía como un completo proyecto de reestructuración del gobierno central de la Monarquía española. El eje esencial de la propuesta orriana venía a ser la creación de un nuevo órgano colegiado capaz de centralizar la actividad administrativa. Un órgano colegiado, al que en el proyecto elaborado por el hacendista francés se denomina «Consejo Real o Gabinete», que vendría a sumarse a los restantes Consejos ya existentes. El Plan de Orry resultó, con todo, moderado. No planteaba drásticas reformas que, sin duda, habrían provocado el rechazo de las tradicionales autoridades administrativas españolas y el consiguiente fracaso de la reforma. Trazaba Orry un plan estructurado en dos direcciones: el Consejo Real y el resto de los Consejos subsistentes $^{\mathrm{I} 46}$. Un plan que conjugaba a un tiempo la necesaria reforma con la prudente restricción, casi imperceptible, de las facultades de los viejos Consejos. La idea era constituir un entramado administrativo paralelo que, sin estridencias iniciales innecesarias y poco aconsejables, lograse el objetivo último de sustituir progresivamente a los inmovilizados tribunales.

El llamado «Consejo Real» lo situaba así Orry en relación directa con el Despacho formado por Felipe V a su llegada a España, que había demostrado ya su ventaja frente al sistema anterior. De nuevo a finales de I7I4, como había ocurrido tras la llegada a Madrid del joven monarca, la constitución del Gabinete o Consejo de Despacho no debía implicar la supresión de los restantes órganos colegiados de gobierno. El Consejo Real propuesto por Jean Orry debía coexistir con el resto de los Consejos, pero ejerciendo el control preciso sobre todos los resortes de la Administración central, de modo que se garantizase el conocimiento por el monarca de la totalidad de los negocios y el seguimiento de los mismos desde el inicio de su tramitación hasta la ejecución final de las decisiones adoptadas en cada caso:

«Propongo un Consejo Real — continuaba explicando Orry- y le divido, como se verá, en tantas partes como ay materias diferentes, para que se traten separadamente cada una, señalo días particulares, hago que alternativamente sigan en Jefe los principales Ministros que los componen, les atribuyo en particular lo que creo puede ser de su carácter, hago pasar por la instrucción de los procuradores generales de los otros Consejos todo lo que tuviere necesidad de informe. No hay mas que estos medios capaces de dar forma a la Administración de los negocios del Rey, y Su Majestad, por este reglamento hará dependientes las operaciones de todos los otros

I45 G. COXE, España bajo el Reinado de la Casa de Borbón, II, pág. .299, señala que los españoles designaron a la nueva organización de los Consejos y del gobierno como «Planta de Orry». Para este autor resulta clara la participación en la elaboración del proyecto reformista del entonces fiscal del Consejo de Castilla, Melchor Rafael de Macanaz. Por su parte H. KAMEN, La Guerra de Sucesión, cit., pág. 134, apunta que, en su tiempo, fue conocida como la planta Macanaz, pero que en realidad pareció deberse más a Orry que al Ministro castellano.

I46 Excepción hecha de los Consejos de Estado — que, en la práctica, apenas fue operativo—, de Aragón que había sucumbido en el marco de la «Nueva Planta» establecida en la Corona aragonesa-, o de los de Flandes e Italia - víctimas de la reducción del Imperio hispánico-, los viejos Consejos continuaron presentes en el aparato de la Administración central de la Monarquía. 
Consejos tan inmediatamente de su Gabinete, que no se ocultará nada a su comprensión, por la aplicación que se dignará tener á su gobierno».

Esta primera medida suponía, pues, la minoración de las atribuciones de los Consejos sin necesidad de recurrir a su supresión. De hecho los Consejos tenían su lugar en el proyecto orriano, persiguiéndose tan sólo la reducción del protagonismo que antaño habían ostentado. La aceptación del Plan propuesto por el Ministro francés no se hizo esperar. Un conjunto de decretos - fechados el io de noviembre de I7I3 y dirigidos respectivamente a los Consejos de Castilla, Órdenes, Indias y Hacienda- venía a ejecutar la primera parte del proyecto de Jean Orry:

«Desde mi ingreso a esta Corona, ha sido una de mis principales atenciones, $y$ deseos, la de reglar los Tribunales de la Corte, y fuera de ella, establecidos en lo primitivo, con tan justas como cristianas, y prudentes leyes, $y$ reglas para su Gobierno, en la mejor administración de la Justicia, y Gobierno de estos Pueblos y Vasallos, que con lo que han acreditado su fidelidad, $y$ constancia en el tiempo de mi reinado, han manifestado lo merecedores que son de ser gobernados con Amor, con Prudencia, $y$ con Justicia, $y$ en consecuencia de estas mis intenciones he solicitado en todo este tiempo, no obstante los embarazos, y cuidados, que há ocasionado la continua Guerra, con que Dios ha sido servido castigar la España, informarme plenamente de los abusos que se han introducido en los Tribunales de la Corte...» ${ }^{\mathrm{I} 7}$.

En estos términos presentaba Felipe V la necesidad de reformar los Consejos. La reorganización que se introducía era el resultado de su tiempo. Desde el principio apareció clara la urgencia de acometer la reforma, pero la guerra había detenido el proceso. En noviembre de I7I3 el conflicto bélico parecía finalmente resuelto a favor de las tropas felipistas. Era, pues, el momento de atender a la reforma de la Administración del Estado, tanto más necesaria tras la que se veía ya como definitiva integración de los países de la Corona de Aragón. La realidad social, política y territorial a la que atendían los antiguos Tribunales había cambiado, de suerte que era preciso modificar la organización de los Consejos con el fin de adaptarlos a esa nueva situación. Lo que realmente preocupaba al monarca era la ineficacia de sus Tribunales. Términos tales como «inobservancia», «abuso» y «confusión» se introdujeron en los Decretos de i3 de noviembre de I7I3 para calificar la situación por la que atravesaban los respectivos Consejos. Finalmente todo parecía reconducirse a una sola idea: «el grave atraso» que padecía la Administración española. La causa de la ralentización del aparato administrativo se simplificó así extremadamente en el texto de la disposición real que canalizaba la reforma, en el que se apuntaba que la ineficacia procedía de la falta de personal bastante en los Consejos. La consecuencia inmediata fue, por tanto, el incremento del número de consejeros y del resto del personal de los viejos Tribunales.

El Plan Orry estaba, pues, en marcha. No había entrado el asesor francés en la descripción detallada de la reforma pretendida. Tampoco los Decretos de io de noviembre de I7I3 se detenían en el análisis de las causas que aconsejaban la reforma. La propuesta de Orry era aceptada sin reservas: resultaba preciso limitar la potestad de los Consejos y nada mejor para obtener este fin que dividir, fraccionar su autoridad, haciéndola recaer en un mayor número de personas.

Culminado el primer paso - la reducción efectiva de los Consejos, pese a la apariencia creada de fortalecimiento- se atendió a la segunda vía apuntada por Jean Orry: la consolidación de la especialización administrativa en el seno del Consejo Real o

I47Real Decreto de ro de noviembre de I7I3 de Nueva Planta del Consejo de Castilla. Puede verse una copia del mismo, remitida el propio día Io de noviembre por José de Grimaldo al Consejo de Indias, conjuntamente con el Real Decreto expedido al Consejo de Indias, en Archivo General de Indias [en adelante AGI], Indiferente, 665. 
Despacho, tímidamente iniciada años antes. Un Real Decreto de 30 de noviembre de $17 \mathrm{II}^{\mathrm{I} 4{ }^{8}}$, ponía así punto final a la reforma, conforme al plan previsto por Orry.

«Después de que se haya formado este reglamento en los tribunales — había dicho el asesor galo ${ }^{\mathrm{I} 9}$ - podrá dar el Rey la última perfección a su Consejo Real, estableciendo quatro Secretarios de Estado».

A diferencia de la primera propuesta - la relativa a la reforma de los Consejostan sólo apuntada por el hacendista francés en su proyecto, en esta otra el discurso orriano aparecía casi como un anteproyecto de la trascendental disposición de reforma de la Administración central. No se había limitado Orry a apuntar la línea de actuación, sino que había descrito pormenorizadamente el objeto de la reforma, el modo de llevarla adelante, e incluso el previsible resultado de la misma:

«Si este plan se ejecuta y la elección de sujetos es buena, verá muy presto el Rey que los negocios mudan de semblante: Cada departimento de los cuatro Secretarios de Estado tomará su regla, $y$ sólo desde aquel día empezará Su Majestad a tener una dirección clara y segura en su Gobierno».

De acuerdo con el Plan de Jean Orry debían designarse cuatro Secretarios de Estado. Junto a ellos, formando parte del proyectado Consejo Real, figuraba también el Veedor general, del que Orry decía que su papel dentro del Gabinete podía parecer enteramente novedoso. El veedor general venía a ser, de este modo, el núcleo central del Consejo Real, pues no sólo debía ocuparse de las cuestiones tocantes a la Hacienda, sino entrar de hecho también en la fiscalización de otras materias. Para hacerse cargo de este empleo, Felipe V había designado ya al propio Jean Orry ${ }^{150}$, a quien el Real Decreto de 30 de noviembre de I7I4 dotó de un auxiliar con el título de intendente universal de la Veeduría General, cuyo principal cometido consistía en asumir la dirección del Departamento de Hacienda, aliviando así la desmedida tarea que recaía sobre el propio Orry.

El tratamiento otorgado a las cinco Secretarías era inicialmente idéntico. Los medios con que se dotó a las diversas oficinas eran también parejos, siendo asimismo uniforme el tratamiento dispensado a las personas que se situaron al frente de cada una de las Secretarías del Despacho ${ }^{\text {I5I }}$. Sin embargo, desde el comienzo destacaron sobre los demás, de una parte, el Departamento de Estado — que, de hecho, aparecía designado ya como «Primera Secretaría de Estado y del Despacho»-y, de otro lado, por su especialidad, el de Hacienda. Al frente de esos dos Departamentos sitúo Felipe V a los dos personajes más relevantes del momento: José Grimaldo, quien desde I705 había venido actuando como el Secretario principal, marginando en la confianza del Rey a los titulares de la otra Secretaría del Despacho, y Jean Orry, promotor de la reforma administrativa que había culminado con el Real Decreto de 30 de noviembre de I7i4. A Grimaldo se le atribuyó la negociación de Estado - la única cuyas competencias fueron mínimamente esbozadas en el texto de la disposición legal de finales de I7I4-, en tanto se reservó para Orry el Departamento de Hacienda, desde el que bien podía supervisarse la actuación de los restantes Secretarios.

I48 Nov. Rec., III, VI, 4, Real Decreto de 30 de noviembre de I7I4, de Nueva Planta para las Secretarías del Despacho y establecimiento de un Consejo de Gabinete y un Intendente Universal de Hacienda.

I49AHN, Estado, 3497, Propuesta de un Consejo Real y Secretarios de Estado.

I50 H. KAMEN, La Guerra de Sucesión, cit., págs. 223-260. Se ocupa este autor de la labor realizada por Orry en lo que se refiere a la reorganización de la Hacienda española, antes y después de su nombramiento como veedor general.

I5I Véase al respecto la Regla General y Fija para las Secretarías del Consejo Real y sueldos de que gozarán los empleados en ellas, en AGS, Dirección General del Tesoro, inv. I6, g. 2I, leg. 6, pl. 4-5. 


\section{I.2. El Ministerio del Cardenal Giudice y la intervención de Alberoni en los negocios públicos}

La muerte de la Reina María Luisa de Saboya había incrementado considerablemente las tensiones existentes en la Corte. La balanza se inclinó inicialmente al lado de la Princesa de los Ursinos y de su protegido Jean Orry, que entre I7I3 y I7I4 habían logrado culminar sus proyectos de reforma del sistema de gobierno de la Monarquía, situar a su más estrecho colaborador en los puestos más relevantes y apartar cuidadosamente a cuantos pudieran estorbar sus planes. Alberoni, atento a todo lo que ocurría a su alrededor, informaba al Duque Farnese, a finales del mes de enero, de que la Princesa, viendo próxima la muerte de la Reina, había conseguido mantener firme el control de todos los asuntos con la ayuda imprescindible de Orry ${ }^{152}$. De este modo, la inesperada expulsión de la Princesa de los Ursinos removió los cimientos del grupo hasta entonces dominante. Durante el mes de enero de I7I5, los artífices del nuevo sistema de gobierno que había echado a andar tímidamente a comienzos de diciembre anterior, se mantuvieron aún en sus empleos, aunque sin duda eran conscientes de que la repentina salida de la Ursinos lo paralizaría todo. El principal beneficiado por los cambios que se esperaban inminentes sería el Cardenal Giudice, quien recobró en el mes de febrero el protagonismo en la escena política española del que hábilmente había conseguido privarle la camarilla de la depuesta Ursinos apenas un año antes. Sin duda Alberoni intervino en la decisión de que se restituyese a España el Cardenal Giudice. Por el embajador francés Saint-Aignan sabemos que Felipe V no estaba decidido a aceptar el regreso de Giudice, que permanecía en Bayona con orden de impedirle entrar en España ${ }^{153}$. El Cardenal contaba, sin embargo, con el respaldo de Luis XIV, con el que mantenía una excelente relación, de suerte que, lejos de preocuparse porque el gobierno de España fuese copado por los italianos, sobre lo que le advertía su enviado en Madrid, el Rey Christianísimo consideró favorable para Francia que Giudice se incorporase al Despacho. Contaba además el Cardenal con otros importantes valedores: la Reina Isabel y doña Mariana de Neoburgo, que se lo había recomendado expresamente a aquella ${ }^{\text {I54 }}$. Por su parte, Alberoni — según él mismo confirma al Duque Farnese- había resuelto servirse de Giudice, enviando una señal de buena voluntad a Francia, dando los primeros pasos para resolver el conflicto con Roma y colocando al frente del gobierno a quien difícilmente le haría sombra ${ }^{155}$. Es tremendamente claro Alberoni en su informe al Duque Farnese acera del papel que se reserva a Giudice:

«sará non tanto de servizio como de decoro per S.M. Questo è - prosigue-un antidoto che ben preparato e servito a tempo e luego, può produrre buoni effetti, pericolosi però se ne facesse soverchio uso».

El I7 de febrero llegaba a España el Cardenal de Giudice y al día siguiente recibía el nombramiento como Ministro de Estado ${ }^{\mathrm{I5}}$. Junto a él se designaron también un Ministro de Guerra, otro de Indias y otro de Marina y Comercio, de modo que parecía haberse adoptado la decisión de revitalizar el Despacho, asignando además a cada uno de sus integrantes ámbitos competenciales concretos. Junto a éstos se mantenían además los viejos Consejos, a la espera de ver en qué quedaban las anunciadas reformas en las que se concentró Giudice en los meses siguientes y los Secretarios del Despacho designados a comienzos del mes de diciembre anterior, que apenas habían tenido tiempo de comenzar a trabajar en sus nuevos Departamentos.

I52 Alberoni al Duque Farnese, Madrid, 5 de febrero de I7I4, en ASN, Farnesiane, fascio 54, fascic. 3.

I53 Carta de Saint-Aignan, de in de febrero de I7I4, cit. C. MARTÍN GAITE, Macanaz, otro paciente de la Inquisición, Madrid, I969, p. 303.

I54 Philippe V et la Cour de France, pp. 595-598.

I55 Alberoni al Duque Farnese, 3 de febrero de I7I5, en A. PROFESSIONE, Il ministero, p. II; P. CASTAGNOLI, Il Cardenale Alberoni, pp. I94-I95.

I56 Gaceta de Madrid del I6 de febrero de I7ı6. 
Pero además la Reina tenía un favorito, que gozaba asimismo de la confianza del Rey que le encomendaba el tratamiento de ciertos asuntos. Los asuntos en los que principalmente encontramos ocupado a Alberoni en los años I7I5 y I7I6 tenían que ver con las complejas relaciones internacionales del momento, en las que demostró moverse con gran destreza. Ya en i7io, por recomendación del Duque de Populi, el Rey había pensado encomendar una delicada misión en Francia a Alberoni, porque indudablemente se conocían y resultaban muy interesantes esos acercamientos oficiosos, ese hacer y dejar ver que no podía hacer más, que Alberoni dominó y en el que contó con el respaldo de los Reyes.

Fue Alberoni quien exploró el estado en que se hallaban las relaciones con Francia y el que negoció sendos tratados con Inglaterra muy favorables para los intereses comerciales ingleses, en la confianza de abrir una brecha que le permitiese asegurar el respaldo o, en su caso, la neutralidad inglesa en el escenario de un nuevo conflicto con Austria por el dominio de Italia. En el tiempo en el que estaban desarrollándose las negociaciones entre Francia y Austria que concluirían en el acuerdo de Rastadt, Alberoni fue introduciéndose con los ingleses. Por mediación de un extraño personaje establecido en ese tiempo en Madrid en calidad de enviado extraordinario de Holanda, el barón de Riperdá, entró en contacto con el enviado inglés en la Corte de Felipe V. Con Riperdá trató Giulio Alberoni de la adquisición de algunos buques que dijo se destinarían al comercio con las Indias y, una vez introducido con éste, solicitó su mediación a fin de concertar una entrevista con el enviado inglés Doddingthon. Según el mismo Riperdá, le habría citado Alberoni, quien exhibió ante él una orden expresa de S.M. facultándole para comprometer la compra de los navíos ${ }^{157}$. Establecido el contacto, Doddingthon transmitió a su Ministro el convencimiento de que, a través de Alberoni, podría alcanzarse algún acuerdo en poco tiempo, pues «es el señor absoluto, porque egerce un influjo ilimitado con la reina, $\gamma$ de este modo con el rey, que gusta poco de negocios y que solo hace la voluntad de su muger. Debo añadirconcluía- que no veo aquí partido ninguno que pueda resistirle» ${ }^{158}$.

Las negociaciones no fueron lo rápido que parecían augurar las palabras del enviado inglés, pero progresaron lo suficiente para tener concluido un primer acuerdo a fines de I7I5. El Tratado se había concertado entre Doddingthon y Alberoni, permaneciendo al margen el Ministro de Estado, Cardenal Giudice, el Secretario del Despacho de Estado, Marqués de Grimaldo y el resto de los miembros del Despacho. Cerrado un acuerdo que pareció aceptable a Felipe V, se dispuso su firma por el Marqués de Bedmar, Ministro de Guerra, al que previamente se confirieron plenos poderes para la firma del Tratado. El relato ofrecido en este punto por Doddingthon es muy preciso, dando cuenta de no haber tratado con nadie más que con Alberoni, de suerte que señala que al Marqués de Bedmar lo vio por vez primera en el acto de la firma del Tratado de Madrid ${ }^{159}$.

El también conocido como Tratado Doddingthon, cerrado en diciembre de I7I5, representó un considerable avance en las pretensiones inglesas en relación al comercio con América, de suerte que inmediatamente se empeñaron en adelantar también las conversaciones acerca de la consolidación del Asiento. La negociación se acercaba ya al punto al que el Rey y Alberoni querían conducirla, revelando el interés de España en Italia, cuando, inesperadamente, Inglaterra firmó un acuerdo con Austria que dejaba a las claras la nula intención de modificar el sistema previsto en Utrecht. Poco después se concluía un acuerdo con Holanda que daba paso a la formación de la Triple Alianza, que se decía defensiva frente al Rey Católico. Alberoni, no obstante, perseveró en su empeño de estrechar relaciones con Inglaterra, única posibilidad de llevar adelante el proyecto

I57 G. COXE, España bajo el Reinado de la Casa de Borbón, II, pág. I57.

I58 Las noticias extraídas de la correspondencia entre Doddingthon y el Ministro Stanhope las tomo de G. COXE, ibídem, II, págs. I57-I92.

I59 Ibídem, p. I59. 
revisionista español. Entre tanto, Giudice, a la sazón Ministro de Estado e individuo que gozaba asimismo de la proximidad del Rey, permanecía al margen de los trabajos de Alberoni. Como lo estaban también Grimaldo o el mismo Consejo de Estado. Alberoni, que no era nada más que el agente en Madrid de una Corte extranjera, disponía de una mejor posición para ofrecer sin comprometer demasiado, para retirarse invocando falta de capacidad por su parte para ir más allá, en suma, para llevar adelante las complicadas negociaciones que desembocaron en un nuevo Tratado con Inglaterra en I7I6, o al acercamiento expreso de Felipe $\mathrm{V}$ a Su Majestad Británica, lo que suponía la quiebra de la tradicional posición española de respaldo al pretendiente. Nominalmente el Ministro de Estado era el Cardenal Giudice, quien había obtenido además el nombramiento de ayo del príncipe de Asturias y acceso a las dependencias de Palacio. Giudice, molesto por su difícil situación, hizo expresión pública de rechazo, que a la postre le valió el ser apartado de un gobierno en el que poco le quedaba por hacer una vez muerto Luis XIV.

La destreza de Alberoni — como dice $\operatorname{COXE}^{160}$ - le había llevado a no comprometer su posición "con tentativas prematuras á fin de apoderarse de las riendas del gobierno". Era Giudice quien formalmente estaba facultado para abordar los asuntos de Estado, pero a todas luces Alberoni intervenía en muchas parcelas del gobierno. Cuando Giudice trató de apartarlo, Alberoni se sabía seguro. Como él mismo había respondido en marzo de I7I5 ante las recomendaciones de prudencia que se le hacían desde Parma, recordándole la reciente caída de la poderosa Ursinos, «la differenza è che la Principessa faceva le parti de Re, Regina e de Tribunali. Io non fo nè l'uno nè l'altro, nè m'ingerisco se non in quello che le Maestà loro m'incaricano» ${ }^{\text {16r }}$.

\section{El bienio Alberoni}

En el inicio de I7I7 Alberoni se sabía firmemente asentado en el Gobierno. La imagen que ofrece COXE $^{162}$ del entonces abate Alberoni es la de un hombre extremadamente calculador, al que guiaba un objetivo perfectamente definido desde el comienzo: conseguir su promoción al cardenalato y convertirse en el elemento clave de la política de Felipe V. Para ello manejó con extraordinaria habilidad sus múltiples contactos con los representantes diplomáticos de las potencias europeas, consiguiendo aparecer a los ojos de éstas como el único capaz de llevar adelante las intrincadas negociaciones en que todos ellos estaban inmersos. En este sentido el embajador inglés escribía a su Ministro encomiando la labor de Alberoni del que decía que sólo su intervención podía hacer posible el adelanto de los negocios. Alberoni, que con cierta frecuencia daba muestras de su pesar por no poder controlar los diferentes tribunales, anunciando su intención de retirarse ante la incapacidad en que le sumía el gobierno en manos de personajes como Giudice, Bedmar o Monteleón. De todos ellos había ido librándose, sin embargo, poco a poco. Al Marqués de Bedmar - que venía ocupándose de los negocios de Guerra dentro del Gabinete desde febrero de I7I5- consiguió excluirlo de la conclusión de los acuerdos que siguieron a la firma del Tratado de Utrecht. Al propio Giudice —en quien recaía la dirección de los asuntos de Estado- fue apartándolo progresivamente de la confianza regia hasta lograr su renuncia como inquisidor general y su salida de España en enero de I7I7, momento a partir del cual la privanza de Alberoni no halló obstáculos. «No creyó, empero, todavía, Alberoni dice COXE- conveniente el tomar un carácter público, encargándose de tamaña responsabilidad. Se contentó por de pronto, con dar impulso á los resortes administrativos, oculto tras el tapiz hasta el momento en que hubiera conseguido la púrpura romana», lo que finalmente logró, pese a los

I60 España bajo el Reinado de la Casa de Borbón, II, p. I50.

I6r Alberoni a Rocca, Madrid, 25 de marzo de I7I5, en BOURGEOIS, Lettres intimes, cit. pág. 386.

I62G. COXE, España bajo el Reinado de la Casa de Borbón, cit., II, pág. 23I. Dice de él que llegó a ser «no menos soberano que el mismo ». 
intentos de impedirlo del Cardenal Giudice —a la sazón en Roma ya en ese tiempo- en el verano de $\mathrm{I} 7 \mathrm{I} 7^{\mathrm{r} 63}$.

Alberoni actuaba ya en este tiempo como principal Ministro, aún cuando, como antes dije, no dispuso nunca de otro «título» diferente al de Favorito o Privado. Es más, Alberoni, a diferencia de otros Privados de los Reyes, no recibió tampoco empleo $u$ honor alguno de manos de Felipe V. No fue consejero de Estado, ni formó parte de alguno de los otros Tribunales. No recibió el título de Secretario del Rey, o cualquiera de los numerosos empleos de la Corte con los que fueron favorecidos frecuentemente los Validoss de los Austrias. Su estrecha relación con la Reina habría podido justificar fácilmente el nombramiento de Alberoni como su Secretario, pero no lo fue, encomendándose este cometido al Marqués de Grimaldo, en lo que lo que se interpretó como una demostración de la confianza que el Rey tenía en su Secretario del Despacho de Estado.

Alberoni continuó siendo durante todo su ministerio el enviado del Duque de Parma en Madrid. Un empleo que desempeñó no sólo nominalmente, pues como se ha ido viendo mantenía regularmente informado al Duque de todo lo acontecido en España. Su condición de representante de una corte extranjera le daba acceso, conforme a la rígida etiqueta de la Corte, a diversos actos y ceremonias. Además, como en la etapa precedente había ocurrido con los embajadores franceses, era ahora el representante de la corte amiga de Parma quien tenía acceso al Rey y al estrecho círculo en que se resolvía el gobierno de la Monarquía. No tenía, pues, título distinto al que habían tenido en su día los Harcourt, Estrèes o Amelot, a quienes se habrían consultado la totalidad de los negocios, incorporándolos, como se vio, al Despacho. Como aquéllos, Alberoni se habría incorporado también a ese círculo reducido a cuyo frente aparece en el bienio I7I5-I6 el Cardenal Giudice. El reflejo del trabajo de Alberoni en las fuentes es aún en ese tiempo inapreciable. No obstante es claro que Alberoni trabaja, que trabaja mucho. Lo dice él en sus constantes correspondencias con Parma y lo dicen de él quienes le tratan, los enviados ingleses o Patiño, por citar algunos de sus más estrechos colaboradores en esta época, aquellos que van conformando su propio círculo de confianza, en el que tuvieron un lugar destacado los hermanos Baltasar y José Patiño, el barón de Riperdá, o el príncipe de Cellamare, de los que se servirá para llevar adelante su ambicioso proyecto a partir de I7I7, una vez que Alberoni se sabe firmemente asentado en su posición.

\section{I. La reforma de los Consejos y de la vía reservada}

El año I7I7 comenzó con lo que ESCUDERO ${ }^{164}$ ha descrito como la «beligerante política de Alberoni para reducir el significado y la importancia de los Consejos». En enero próximo ya a lograr el Capelo cardenalicio y con Giudice fuera de escena- Alberoni empezó a sentar las bases de su inminente control de todo el aparato de gobierno. Separó de la presidencia del Consejo de Indias al Conde de Frigiliana, sustituyéndolo por don Andrés de $\mathrm{Pez}^{\mathrm{T} 65}$. Logró el nombramiento de don José Patiño como intendente general de la Marina, confiriéndole al propio tiempo la Presidencia de la Casa de Contratación de las Indias $^{166}$. Dio nueva planta a los Consejos y fue preparando, al propio tiempo, la reforma también de las Secretarías del Despacho.

I63 Ibidem, p.205.

ı64"La reconstrucción de la Administración Central", cit., pág. II7.

I65 AGI, Indiferente, leg. 542, ff. $7 \mathrm{r}-8 \mathrm{v}^{\circ}$, Real Decreto de 20 de enero de I7I7; La noticia fue recogida en la Gaceta de Madrid, núm. 4 (I7I7), del martes 26 de enero.

I66Gaceta de Madrid, núm. 6 (I7I7), del martes 9 de febrero. El nombramiento tuvo lugar el 27de enero y —según J. MARTÍNEZ CARDÓS, "Don José del Campillo y Cossio", en Homenaje a Ciriaco Pérez-Bustamante, II, Madrid, I969, pág. 509- confirió a Patiño las facultades propias de un verdadero Ministro. El título de 
COXE describe, por boca del enviado inglés Doddington, el estado de la Administración española en el comienzo de I7I7, en los siguientes términos:

«Creo que todavía habrá aquí algunos cambios, pero pienso también que el temor de verlos realizados paraliza los negocios. El motivo que he tenido para desear estos cambios y hasta para solicitarlos ha sido el ver á los Ministros en una especie de mutua dependencia; porque en el estado que tienen ahora las cosas, existe poca confianza entre estos señores $y$ Alberoni, no permitiéndoles este hacer lo que ellos quisieran, y como por otra parte debe pasar lo que él hace por manos de ellos, tratan de hallar un sesgo favorable ó de poner cuantos tropiezos pueden, lo cual da á todo un aspecto maravilloso de confusión y desorden. Deseo, de todas veras salir de semejante estado de embrollo, de cualquier modo que sea ${ }^{167}$.

Esos «cambios particulares en la administración» tenían por fin, según el historiador inglés, incrementar el poder de Alberoni:

«Pero no era excluyendo á ciertos agentes de la autoridad, ni cambiando una rueda por otra como podía Alberoni aumentar su poder. Los Ministros españoles, aun aquellos mismos que debian su nombramiento a Alberoni, no consentían en humillarse ante el influjo de un extranjero advenedizo, $y$ se oponían unas veces directa, $y$ otras indirectamente á las medidas que tenían por objeto el destruir las costumbres antiguas ó desarraigar los abusos sancionados por el tiempo. Alberoni introdujo, pues, un sistema nuevo que cambiaba esencialmente la dirección de los negocios de cada ministerio, y que ponía todo el poder en sus manos, constituyéndose él en depositario único de la confianza real, $y$ principal órgano de la voluntad del monarca» ${ }^{168}$.

Las reformas alcanzaron así no únicamente a los Consejos, sino también, al propio tiempo, a la vía reservada. En el mes de enero, sendas disposiciones alcanzaron de lleno al conjunto de los Consejos y las Secretarías del Despacho. Con la finalidad expresamente declarada de agilizar la tramitación de los expedientes, un Decreto de 20 de enero resolvió la centralización de todas las oficinas de los Consejos en las dependencias reservadas al efecto en el Palacio que había sido la residencia de la Reina doña María Ana de Austria ${ }^{\text {169 }}$. Al propio tiempo se señalaron las obligaciones de los responsables y dependientes de las diversas Oficinas, el sistema de elección y separación de estos últimos y la incompatibilidad con el desempeño de otros empleos ${ }^{170}$. Fechados asimismo el 20 de enero, otros decretos se ocuparon de perfilar el papel que correspondía a los viejos Consejos en la nueva estructura administrativa, reduciendo considerablemente el ámbito de sus competencias y declarando las que debían discurrir por la vía reservada de las Secretarías del Despacho.

La reforma -que se completó con nuevas disposiciones promulgadas a lo largo de I7I7- había comenzado a fraguarse en los meses anteriores. A finales de diciembre de I7i6, Alberoni proyectaba ya el asalto definitivo al régimen anterior, que le permitiría asegurarse el completo control de los negocios. En su correspondencia habitual con el Conde Rocca, manifestaba con claridad el alcance de sus proyectos:

«Ci resta a parlare di quel sacro areopago del Consiglio di Stato, l'autoritá del quale era che il Re non potevano senza il di lui assenso fare nè guerra nè pacfe, nè alleanza; non potevano

Intendente general de Marina fue expedido el 28 de Enero de I7I7 y o recoge J.L. PANDO VILLARROYA, La Administración en la Armada Española, Madrid, I985, págs. Io-ı2.

I67Carta del enviado británico Doddington a su Ministro de Estado, de II de febrero de I7I7, en España bajo el Reinado de la Casa de Borbón, cit., II, pp. I9I-I92.

I68Ibidem, pág. I92.

I69 Nov. Rec., IV, II, I; La noticia del mismo se insertó en la Gaceta de Madrid del martes 2 de febrero;

I70 Sobre el conjunto de las disposiciones de esa misma fecha, dirigida a los diferentes Tribunales, que vinieron a complementar a aquella de carácter general, señalando reajustes en la plantilla del Consejo, o regulando los salarios que deberían percibir sus integrantes; véase M. MARTÍNEZ ROBLES, Los Oficiales de las Secretarías de la Corte, Alcalá de Henares, I987, págs. I2 I y ss. 
accasarsi, nè accasare $i$ loro figli senza l'approvazione del medesimo Consiglio. I ministri di fuori non potevano fare ricorso alcuno nè rappresentazione ai Re che per il canale del medesimo Consiglio con le lettere a sigillo alzato: ed in fine, in mano dei Consiglieri di Stato era la morte e la vita di tutti $i$ ministri che erano fuori impiegati. Se questa suprema autorità sussistesse, crede ella che si vedrebbe quello che dice, cioè contemporaneamente ordinato ed eseguito? ${ }^{\mathrm{IT}}$.

Era preciso — proseguía su análisis de la situación— reducir los Consejos al puro voto consultivo y que el Consejo de Estado conservase, tan solo nominalmente, su posición. Unos días más tarde, Alberoni recibía un informe elaborado por el Secretario del Consejo de Estado, Juan de Elizondo en el que se precisaban los relevantes asuntos despachados en este tribunal, el prestigio secular que rodeaba al Consejo y la preeminente consideración que siempre había correspondido a su Secretaría. El informe -fechado el 4 de enero de I7I7- respondía a una consulta formulada verbalmente a Elizondo por el mismo Alberoni $^{\text {T72 }}$. De su tenor se desprende sin dificultad que elinistro italiano habría dejado entrever al Secretario Elizondo sus proyectos de reforma en relación al conjunto de los Consejos, de suerte que éste centró fundamentalmente su dictamen en argumentar acerca del relevante cometido del Consejo de Estado y en particular de la Secretaría del Consejo, dejando ver que no había llegado a entenderse el por qué de la reducción de las anteriormente dos oficinas a la única Secretaría existente en ese momento. Utilizó Elizondo dos argumentos: de una parte, el prestigio de la Secretaría de Estado, derivado de los negocios que desde siempre habían pasado por la misma y del que correspondía a los Ministros del Consejo. En segundo lugar, la preeminencia de los Secretarios de Estado, aduciendo que su autoridad no era inferior a la de los Secretarios del Despacho reclamando que los sueldos y consideraciones atribuidos a unos y otros fueran realmente acordes a la gravedad de los negocios que manejaban-, al tiempo que los distanciaba de los Secretarios de los restantes Consejos. Se atrevió Elizondo, por último, a manifestar su convencimiento de que Alberoni no estaba siendo bien asesorado, de manera que podían haberle inducido a error al aconsejarle relegar a un segundo plano al Consejo de Estado ${ }^{173}$ y llegaba incluso a advertir al Ministro italiano que la decisión que se adoptase en relación a este tribunal debería estar bien meditada, ya que «no fuera bien visto dentro $y$ fuera de España que a poco se hallase precisado S.M. (por los graves inconvenientes que pueden resultar de estas novedades, que siempre son odiosas) ha desacer mañana lo ejecutado hoy».

Pese a las advertencias del Secretario del Consejo, Alberoni siguió adelante con sus designios, de suerte que un decreto de $\mathrm{I}^{\mathbf{0}}$ de mayo de $\mathrm{I}_{\mathrm{II}} \mathrm{7}^{\mathrm{T} / 4}$ dispuso la unión de las Secretarías de los Consejos de Estado y de Guerra en una única, a cuyo frente permaneció Juan de Elizondo. Alberoni había completado así el golpe a los Consejos. En enero del año siguiente, el Ministro parmesano escribía al respecto:

«Può ella immaginarsi cosa si dice contro questo maledetto Italiano che ha voluto, per rendersi dispotico del comando, attirare a sè tutta quella autorità che stava divisa in più sacri

I7I Alberoni a Rocca, Madrid, 2I de diciembre de I7I6, en E. BOURGEOIS, Lettres intimes, cit., pág. 5I2.

I72 AHN, Estado, 28I2/2, Minuta de la respuesta que dio D. Juan de Elizondo, Secretario de Estado al Abad Alberoni, sobre las incumbencias del Consejo de Estado y de su Secretaría.

I73 «Y correspondiendo a la confianza que se ha hecho de mí en este asunto abierta y christianamente diré lo que siento; creo firmisimametne (y assi lo publico siempre que lo permite la oportunidad) que el deseo del Sr. Conde de Alberoni es de procurar y conseguir el mayor acierto en el servicio del ; no sé si en los sujetos de quien se vale para adquirir las noticias que son menester para este fin concurren las calidades y experiencias que se necesitan para el acierto de una tan grande y ruidosa obra, y si estos sujetos proceden en sus proposiciones con sinceridad de animo, y sin pasion, mirando solamente a su propio util y elevacion, con ruina universal. No sé quienes son y ha saberlo congeturara sus fines aunque el conocimiento expreso de los hombres es inapurable, porque a cada paso mudan de semblantes y de intenciones», ibídem.

I74 Publicado por J.A. ESCUDERO, Los Secretarios, III, doc. III. 
consessi venerati, non che rispettati da tanti gloriosi Re Cattolici; e pure, signor conte mio caro, se le cose devono andar bene, debe essere cosi» ${ }^{175}$.

La política reformista impulsada por Alberoni alcanzó de lleno tanto a los Consejos como a las Secretarías del Despacho. Apenas dos meses después de iniciada la reforma de los Consejos, se articuló también un nuevo esquema ministerial en tres Departamentos, resultado de la supresión del de Hacienda, cuya negociación quedaba vinculada a partir de ese momento a la Secretaría de Estado y del Despacho de Gracia, Justicia y Gobierno Político. Se mantuvieron, por otra parte, las de Negocios Extranjeros y de Guerra y Marina. Por vez primera, además, la propia disposición detallaba pormenorizadamente el alcance de las competencias asignadas a cada uno de los tres Ministerios subsistentes ${ }^{176}$.

Disminuidos los Consejos por efecto de los decretos de enero de I7I7, venían, tres meses más tarde, a declararse abiertamente las competencias de los correspondientes Departamentos ministeriales. En la práctica, sin embargo, también éstos serían a su vez preteridos por Alberoni, quien, a tal efecto, trató de colocar al frente de cada una de las tres Secretarías del Despacho a quienes no estorbasen su privanza con los Reyes ${ }^{177}$. La nueva Secretaría del Despacho de Justicia, Gobierno Político y Hacienda quedó en manos de José Rodrigo Villalpando, Marqués de la Compuesta, quien desde el mes de enero aparecía al frente de los Departamentos aún separados ${ }^{178}$, en tanto los otros dos continuaron dirigidos por el Marqués de Grimaldo y por Miguel Fernández Durán, ya que no pudo en este caso Alberoni -a decir del Marqués de SAN FELIPE ${ }^{179}$ - ni separar al primero de la confianza del Rey, ni encontrar un sustituto para el segundo.

La política reformista desplegada por Alberoni potenció la llamada «vía reservada», llevando además la «reserva» a su extremo, toda vez que los propios Secretarios del Despacho fueron a su vez relegados en la práctica por el propio Alberoni. En este sentido, se ha hablado de este modo de dos suertes de «reserva». Una que alcanzaría a los Consejos, que cederían competencias a favor de los correspondientes Departamentos ministeriales y, otra, que supondría en la práctica también la separación de estos últimos, favoreciéndose así el despacho de los negocios por el Rey mismo. Se habla así de la existencia de dos vías, que Gildas BERNARD designa como «de Estado»y «reservada», respectivamente. Sobre este particular, ESCUDERO ha puntualizado que la segunda de las modalidades apuntadas por el investigador francés no se dio en la práctica en beneficio únicamente del Rey, sino en la medida en que el Rey avocaba un asunto para despacharlo con quien considerase conveniente, o bien en los casos en que un «personaje excepcionalmente calificado reclama él mismo y resuelve el tema, actuando, expresa o tácitamente, en nombre del monarca» ${ }^{180}$. Con Alberoni, en efecto, la llamada «vía reservada» se habría convertido en el cauce ordinario para el despacho. Alberoni, que había procurado desde el comienzo de su privanza ir apartando a todos los demás Ministros del entorno de Felipe V, había logrado, a lo largo de I7I7, una inmejorable posición. Los asuntos de Estado -aquellos en los que con más agilidad y destreza se movía Alberoni- habían sido ya sustraídos al Consejo, que mermado en su posición anterior, permanecía prácticamente inactivo. "Tutti i ministri di fuori hanno ordine di non havere carteggio alcuno con $i$ ministri del detto Consiglio, il quale è ridotto a tre Consiglieri, che s'uniscono due o tre volte all'anno», comunicaba Alberoni a Parma a mediados

I75 Alberoni a Rocca, Madrid, I3 de junio de I7I8, en E. BOURGEOIS, Lettres intimes, cit., págs. 585-586.

I76 Decreto de 2 de abril de I7I7, en Nov. Rec., III, VI, 5.

I77 Afirma P. MASSUET, Historia del Duque de Riperdá, cit., que Alberoni sólo quería tener en su confianza a sujetos que no pudiesen hacerle sombra.

I78 Así se desprende de la noticia inserta en la Gaceta de Madrid, núm. 2 (I7I7), del martes I2 de enero.

I79 Comentarios, cit., pág. 267.

I80 G. BERNARD, Le Secrétariat d'État et le Conseil espagnol des Indes, Geneve, I972, pág. 27. y J.A. ESCUDERO, “La reconstrucción de la Administración Central”, cit., pág. II7. 
de junio de I7I8. En efecto, la correspondencia de Estado debía dirigirse por la vía reservada, lo que era tanto como decir por manos de Alberoni, que había relegado, de hecho, al titular de la Secretaría del Despacho de Estado a un papel secundario ${ }^{\mathrm{r} 8 \mathrm{I}}$. En efecto, Alberoni prácticamente prescindió de Grimaldo, con quien no tenía en este tiempo buena relación. Por otra parte, el curso de los negocios hizo cobrar mayor protagonismo al responsable de la Secretaría del Despacho de Guerra, Miguel Fernández Durán, quien acompañaba en este tiempo habitualmente a los Reyes en las Jornadas y del que se servía Alberoni.

\subsection{Los poderes de Alberoni. La praxis de gobierno}

Desde la publicación hace unos años de un documento escrito de la propia mano de Felipe V, fechado el 26 de octubre de I7I7, por el que se atribuyeron amplios poderes a Alberoni, ha venido sosteniéndose que con el mismo se reconocía a Alberoni la condición de Primer Ministro de la Monarquía española ${ }^{\mathrm{r} 82}$. Un documento que -como antes dije- se ha identificado con el codicilo del testamento de Felipe $\mathrm{V}$ que insistentemente fue reclamado a Alberoni en los días que siguieron a su caída en desgracia ${ }^{183}$.

El codicilo que finalmente se habría recuperado de entre los papeles de Alberoni, no se conserva sin embargo entre éstos, ni fue remitido tampoco junto con el resto de la documentación reunida para la causa seguida en Roma a Alberoni tras su caída. Sí se hizo constar, sin embargo, por expreso mandamiento del monarca, la declaración del Marqués de Grimaldo afirmando haber conseguido arrebatarle ese documento a Alberoni de resultas del registro al que se sometió su equipaje en Alicante y Cataluña.

Si es conocido, sin embargo, el tenor literal del otro documento -el poder, que se conserva original entre la documentación de Alberoni conservada en la sección de Estado del Archivo Histórico Nacional-, aquel por el que Felipe V habría autorizado a Alberoni a actuar en su nombre en los más relevantes asuntos que en ese momento les ocupaban y que se referían, como no, a la convulsa política internacional. Un documento que respondería así a la recomendación que, según indica SAN FELIPE ${ }^{184}$ le habían hecho al Rey sus médicos de que se apartase absolutamente de los negocios más graves, motivo por el que Felipe $\mathrm{V}$ resolvió dejarlos en manos de Alberoni.

El citado documento, autorizado con la firma del monarca, concedía a Alberoni poderes ilimitados para «tratar y concluir qualquiera Paz con qualquiera Potencia de Europa», disponiendo a este único efecto que pudiese librar cuantos caudales fueren precisos y que dispusiere las órdenes precisas para fortalecer el ejército y la armada, «a fin que estando Yo armado pueda lograr una Paz honrable y ventajosa». ¿'Tiene este poder el alcance que se ha pretendido, esto es, la efectiva delegación de la soberanía en manos de Alberoni?. Entiendo que no. En primer lugar porque no se trata de un poder de alcance general, sino ajustado al tratamiento del negocio principal del momento, que no era otro que ajustar un nuevo sistema que garantizase las posiciones de España en el Mediterráneo. Para PERONA, sin embargo, Felipe $\mathrm{V}$ habría confiado a Alberoni algo más que las relaciones exteriores, poniendo a su disposición también la Hacienda, la Guerra y la Marina, lo que, a pesar de reconocer el carácter instrumental de estos negociados en relación a las primeras, le lleva a concluir que «el sentido del poder ha cambiado por completo. El monarca ha delegado el ejercicio

I8I B. BADOR, Los orígenes, cit., págs. 40-42.

I82En este sentido, B. BADOR, idem, D. PERONA, “Apuntes sobre el perfil institucional...”, cit., pags. IO7Io8 y C. MAQUEDA, "Reformismo, Diplomacia y VirReinato de Nueva Granada”, en AHDE, 74 (2004), págs. 242 y ss.

I83C. DE CASTRO, A la sombra de Felipe V, cit., pág. 333.

I84 Comentarios, cit., pág. 269. 
de su soberanía en una persona concreta ${ }^{\mathrm{185}}$. Recientemente ESCUDERO ha matizado estas apreciaciones, recordando que lo que se confiere a Alberoni «no es, según parecer, un poder extraordinario de carácter general, como sería el propio de un Primer Ministro, sino otros más concretos, aplicados a la política internacional en paz o en guerra (de ahí las estaría atribuyendo la política internacional, facultándole para concluir acuerdos o referencias a las cuestiones de Marina y Hacienda, conexas a ella) ». Es decir, se le estaría atribuyendo la política internacional, facultándole para concluir tratados con otras potencias y autorizándole a invertir en esa empresa los caudales que fueren necesarios.

El documento firmado por el Rey contiene efectivamente dos disposiciones diferentes. En su primera parte, responde al esquema clásico de apoderamiento a favor de un Ministro plenipotenciario al que se faculta para negociar como si el Rey mismo lo hiciere. En este sentido, se utilizan las expresiones formales habituales: «... concedo todo el poder, autoridad $y$ facultad que requiere, sin limitación alguna, para tratar $y$ concluir.. », o «y por este efecto prometo en Fee y palabra Real que passare y cumplire lo que dicho Cardenal Alberoni estipulará, concluirá y effectuará en mi nombre con cualquiera Potencia de Europa ${ }^{186}$. Además, como se ha advertido por todos, se trata en todo caso de un poder limitado en el tiempo, sujeto a término, válido hasta que se consiga el tratado.

La segunda parte, sin embargo, no se ajusta a la fórmula de una escritura de poder. No está pensada para ser exhibida ante otros Ministros facultados asimismo para alcanzar complejos acuerdos internacionales. Es una disposición de consumo interno, que responde sin más, probablemente, a la situación concreta de debilidad por la que en ese momento atravesaba el monarca, temporalmente incapacitado para hacerse cargo del gobierno y a quien sus médicos habrían recomendado apartarse momentáneamente de los negocios. Es por esta razón y con la finalidad de que no se detuviere el curso de los asuntos más urgentes, señaladamente el aprovisionamiento de la armada y cuantas medidas tocantes a Guerra y Marina fuese preciso adoptar para asegurar la posición de fuerza que el Rey Católico necesitaba esgrimir en la negociación de la paz, por lo que se dice que Alberoni podrá disponer las órdenes necesarias y que quienes las reciban deberán acatarlas, pues el Rey le ha autorizado a expedirlas. Ni más ni menos, pues, de lo que unos meses antes se habría ordenado a los jefes militares al frente de la expedición destinada a Cerdeña: que las órdenes que les transmitiese Alberoni debían entenderse dispuestas por el mismo Felipe $\mathrm{V}^{\mathrm{1} 7}$.

Se ha sostenido, por último, que el poder debió ser secreto, no siendo conocido por sus contemporáneos. Se menciona al respecto la falta de referencias al mismo en la minuciosa crónica del Marqués de San Felipe. El documento ciertamente pasó inadvertido, pero no tanto quizá por su naturaleza secreta - lo que como ha advertido ESCUDERO carecería de sentido de haberse buscado de propósito ${ }^{188}$ - , como porque no se le atribuyó mayor alcance que el apreciado en otras disposiciones anteriores. De hecho, nada hace pensar en cambios en la posición institucional de Alberoni, quien con posterioridad a la enfermedad del monarca continuó conduciéndose como hasta entonces. Por otra parte, la pronta recuperación del monarca habría dejado a su vez sin efecto la previsión anterior, al aparecer Felipe V de nuevo al frente de todos los negocios. Nada habría cambiado, por

I85 “Apuntes sobre el perfil...”, cit., pág. I07.

I86 En términos muy similares puede verse el poder otorgado al teniente general D. Patricio Laules, designándolo como Ministro plenipotenciario para establecer una alienza firme y duradera con Suecia, AHN, Estado, 2884/I, Cartas escritas al de Suecia e instrucciones dadas a D. Patricio Laules. Constan asimismo una carta para el de Suecia escrita en francés y una Instruction pour D. Patrice de Laules, marischal de campo de mes armées.

I87 La disposición fechada el 29 de junio de I7I7 y remitida al intendente general de Marina, José Patiño, al jefe de Escuadra Manuel Mari, al teniente general Marqués de Lede y al capitán general de Cataluña, príncipe Pío, la cita A. RODRÍGUEZ VILLA, Patiño y Campillo, Madrid, I882, pág. 30.

ı88 “Privados, Validoss y primeros Ministros”, p. 28. 
tanto. Alberoni continuaba junto al monarca, reconocido por todos como el principal Ministro de la Monarquía, si bien no habría recibido, ni recibiría nunca, título alguno que lo acreditase como tal, conservando el Rey la apariencia de su gobierno absoluto y actuando Alberoni como su Ministro y hombre de confianza.

En la práctica del gobierno, la intervención de Alberoni se habría traducido en una relegación de los tribunales y Secretarios. Manteniéndose, sin embargo, formalmente la estructura de gobierno anterior, el papel desempeñado por Alberoni debía hacerse encajar en aquella y a juzgar por lo señalado por SAN FELIPE ${ }^{189}$ el acoplamiento no resultó sencillo. Desde el comienzo de I7I7, Alberoni había ido afianzándose en su papel de Ministro principal, si bien, como apunta COXE, no parecía querer aún desvelarse por temor a perjudicar su proyecto de obtener la dignidad de Cardenal, que finalmente le fue concedida en el verano ${ }^{190}$. Las reformas introducidas en los meses anteriores en relación a los Consejos y Secretarías del Despacho, habían dejado abierta la puerta a la relegación en la práctica de todos ellos, que cederían ante el nuevo esquema de Despacho por el monarca con el concurso de su principal Ministro. Alberoni había logrado ir alejando a los otros Ministros del entorno de Felipe V, de suerte que únicamente él tenía trato verbal con los mismos, en tanto Grimaldo, Fernández Durán y Rodrigo comunicaban por escrito al Rey los asuntos relativos a sus respectivos Departamentos. El Marqués de Grimaldo describe tiempo después las maniobras de Alberoni, señalando como se les había ido apartando paulatina «e insensiblemente» hasta verse definitivamente privados del acceso personal al monarca. La situación había alcanzado ya ese punto hacia el final de I7I7, pues Alberoni aprovechó la ocasión de la enfermedad del Rey —-según refiere Grimaldo- para apartar del entorno del Rey a todos sus otros servidores:

«... trató de irme separando insensiblemente $y$ poco a poco de mi tal qual manejo, $\gamma$ de la continuacion que este mismo me facilitaua de veer $y$ hablar al Rey con frequencia, $y$ con efecto valiendose de la ocasión de la enfermedad que padecio S.M. en el Escorial por el Mes de octubre de 1717 (mediante la qual logró ser y quedar expotico en el manejo) me fuè abstrayendo del que yò tenia, $y$ a dejarme casi sin alguno, logrando por este medio el que yó no viese al Rey, que S.M. no me llamase ni tomase orden alguna a voca suia para nada $y$ por el consiguiente que no interuiniese ni fuese sauidor de cosa alguna de las que en aquel tpô, $y$ desde entonces asta su retirada de Madrid, se hicieron, sino tal qual en q se vehia precisado a valerse de mi» ${ }^{\text {I91 }}$.

Era Alberoni quien en este tiempo, a la vista de todos, trataba con el monarca los asuntos relativos a la política exterior española, si bien formalmente la correspondencia con las Cortes europeas continuaba recibiéndose a través de la Secretaria del Despacho de Estado, de suerte que su titular, hasta poco tiempo antes el primero y más próximo de los Secretarios del Rey, daba cuenta por escrito de los despachos recibidos, remitiéndolos con la correspondiente minuta al monarca y aguardando respuesta por escrito acerca de la resolución que debía recaer en cada caso. Las respuestas de oficio se las hacía llegar el mismo Alberoni ${ }^{\text {I92 }}$, quien paralelamente mantenía asimismo correspondencia regular con algunos de los principales agentes españoles en el exterior ${ }^{193}$.

I89 Comentarios, cit., pág. 3I3.

I90 La Bula de creación de cardenal a Giulio Alberoni, en AHN, Estado, 2884/2.

I9I AHN, Estado, 2884/3.

I92 Pueden verse comunicaciones sobre diferentes asuntos entre Alberoni y Grimaldo, fechadas en el último trimestre de I7I8, en BNM, mss. 2I7I, cit. por B. BADOR, Los orígenes ,cit., pág. 4I.

I93 En ibídem, 2884/3, puede verse la correspondencia entre Alberoni y el príncipe de Cellamare, entre I7I8 y I7I9. Asimismo, en ibídem, 2884/2, se conservan algunas cartas cruzadas con el cardenal Acquaviva en I7I8. y en ibídem, 38I7 y 4838 pueden consultarse cartas dirigidas a Alberoni por el Marqués de San Felipe en los años I7I7-I7I9. 
«Todo el arte era apartar del Rey a cuantos podían influir consideraciones que avivasen la reflexión, $y$ tenerle falto de noticias. Por eso —continúa SAN FELIPE ${ }^{194}$ - había mandado a los Ministros que servían en las cortes extranjeras que ni a los Secretarios del Despacho Universal las comunicasen, $y$ sólo a él en derechura se escribiese, para que estrechado más el Rey a mendigar avisos de lo que pasaba, ni aún pudiesen los Secretarios dárselos, porque éstos de oficio le presentan las cartas de los Ministros, que no deja el Rey de leerlas, porque es difícil en materia de Estado minutarlas; por eso las quería Alberoni en su poder, porque dejando la formalidad de llevarlas al Rey, sólo le decía lo que no embarazaba a su idea, conociendo la oportunidad y la sazón».

No obstante, Grimaldo habría continuado recibiendo los despachos dirigidos a Felipe V y tratado de darles el curso ordinario, de suerte que en ocasiones se le respondía que el Rey estaba ya enterado de lo que aquél pretendía comunicarle y que no era preciso que remitiese más noticias al respecto ${ }^{\mathrm{r} 95}$.

Idéntica práctica a la seguida en relación a los asuntos de Estado se habría mantenido en las otras negociaciones, de suerte que aún cuando indudablemente Alberoni intervenía en todos los negocios, la tramitación de los respectivos despachos continuaba disponiéndose a través del Secretario del Despacho correspondiente y muy frecuentemente por parte del Marqués de Tolosa, quien acompañaba habitualmente a los Reyes y a Alberoni en las Jornadas, tramitándose a través de su oficina los asuntos que el Rey atendía durante las mismas. La preferencia por hacerse acompañar por Miguel Fernández Durán la explica SAN FELIPE ${ }^{196}$ señalando que Alberoni recelaba de Grimaldo y que además necesitaba al Marqués de Tolosa para disponer a través de él las órdenes tocantes a Guerra. Afirma asimismo este cronista que las relativas a Estado no las confiaba Alberoni a nadie, disponiéndolas por su propia mano, o sirviéndose de alguno de sus Secretarios particulares. Entre la documentación incautada a Alberoni y reunida por Grimaldo que, al efecto, habría cursado los oportunos requerimientos a los Consejos, Tribunales y Secretarías ${ }^{\mathrm{r}}{ }^{97}$, pueden verse minutas de cartas dirigidas al Cardenal Acquaviva dando cuenta de la partida de la escuadra española dirigida contra los turcos en I7I6 y explicando que con ese motivo pasaría a Roma monseñor Albarni ${ }^{198}$, así como la minuta en italiano del escrito remitido a las diferentes Cancillerías europeas con ocasión de la invasión de Cerdeña ${ }^{\text {I99 }}$, o la carta dirigida al Duque de Orleans, en noviembre de I7I7, tratando de persuadirle de la conveniencia de su unión con España ${ }^{200}$, o las escritas por el príncipe de Cellamare, informando de lo tratado por el embajador imperial en la audiencia extraordinaria que le había concedido el pontífice en marzo de I7I 8 y de lo posteriormente tratado en el Sacro Colegio Cardenalicio ${ }^{201}$. Por este tiempo, Alberoni trató también de defenderse de las acusaciones vertidas sobre él de haber tomado parte en una conjura en Francia en la que había estado implicado el mismo Cellamare, por lo que hizo circular escritos que lo

I94 Comentarios, cit., pág. 3I3.

I95 C. de CASTRO, A la sombra de Felipe V, cit., pág. 332. Hace referencia a unas cartas del cardenal Acquaviva, remitidas por Grimaldo a Fernández Durán, en julio de I7I8 y señala que la respuesta por parte de Alberoni fue que los ya estaban al corriente de todo a través de su propia correspondencia diplomática.

I96 Comentarios, cit., pág. 313.

I97 AHN, Estado, 2884/I, s/fha.

I98 En una esquela adjunta se indica que parece ser para el cardenal Acquaviva. No está fechada, ibídem.

I99 Es una carta escrita por el mismo Alberoni que, según la anotación de la cubierta, se dirigió a Bubb, al Duque de Saint-Aignan y a Su Santidad, AHN, Estado, 2884/I, s/fha.

200 AHN, Estado, 2884/I, Carta al Duque de Orleans, 8 de noviembre de I7I7.

20I Extracto de cuanto el embajador cesáreo católico a representado a Su Santidad en su Audiencia extraordinaria del miércoles I6 del corriente de i7ı8 y subsecuentemente al Sacro Colegio de Cardenales y Copia (impreso) de carta escrita por el príncipe de Cellamare al señor Alberoni, sobre el contexto de la representación hecha a Su Santidad por el embajador austriaco, en la audiencia extraordinaria de i 6 de marzo de este año de I7ı. La carta lleva fecha de París, i8 de abril, ibídem. 
exculpaban de cualquier intervención en la misma ${ }^{202}$. Entre su correspondencia se hallaron también minutas de las cartas dirigidas por Felipe V al Rey de Suecia o al de Sicilia, con motivo de las alianza que se pretendía con el primero y de las pretensiones de España en relación a la isla de Sicilia — que aseguraba tendría España solo en depósito - tratando de persuadir al Duque de Saboya a la unión con España y para que hiciese entregar las plazas de Sicilia a las tropas del Rey Católico, facilitando así que pasasen a la conquista de Nápoles ${ }^{203}$.

La mayor presencia de Fernández Durán junto a Alberoni tendría que ver sin duda con el hecho de que aquél era el titular del Departamento de Guerra y ésta era la principal ocupación del Rey y de Alberoni desde mediados de I7I7. A la exitosa expedición a Cerdeña habrían seguido el fracaso en Sicilia y la ruptura definitiva del aparente equilibrio que dio lugar a la incursión de tropas británicas en diferentes puertos del norte peninsular. Alberoni y Fernández Durán disponían día a día los despachos precisos para hacer frente a la delicada situación. Cada uno desempeñaba su papel, como se desprende de la abundante correspondencia mantenida entre Alberoni y el jefe militar enviado a las provincias vascongadas, Blas de Loya, a lo largo de los años i7ı8 y i7ı9. En muchas de esas cartas puede leerse «veo por la de V.Ema me previene ha mandado a D. Miguel Durán de orden de S.M. se despache un expreso ordenándome..", "he mandado a D. Miguel Duran comunique a V.S...», o «habiéndome enterado de la carta de V.S. de ... $y$ de su representación, de que me ha dado cuenta D. Miguel Durán... ${ }^{204}$. Alberoni, pues, mantenía correspondencia regular con Blas de Loya, transmitiéndole extraoficialmente las órdenes precisas en nombre del Rey, en tanto aquél recibía después puntualmente de manos de D. Miguel Fernández Durán el correspondiente oficio $^{205}$. Entre las cuestiones abordadas a tres bandas es posible destacar la preocupación por la preservación de los astilleros del cantábrico, ante el temor cierto de que fuesen destruidos por los franceses o ingleses ${ }^{206}$, la prisión del coronel Boissimene ${ }^{207}$, o la preparación de la expedición secreta a Bretaña ${ }^{208}$. Mención aparte merece el conflicto suscitado por el traslado de las aduanas existentes en el interior de las llamadas provincias exentas hasta la costa del cantábrico. La decisión, comunicada en agosto de I7I7, venía

202 «Questo é una copia del Biglieto che fù scrito al Nunzio del Papa con simile aquello che anno ricevuto tutti gli ministri de Prencipe Residenti in Parigi; pero mezzo del quale injustamente si pretende far mi autore di una conspirazione; quando q lettere intercetate chiaramente apparisce aver io semplicemente trasmesso à S.M. le proposizioni di alcuni, che pretendevano sugerive rimedi per il bene delle stato; per la conservaziones di S.M. Xt., e per la stabile unione delle due Corone», ibídem. En BNM, mss. II.oı8, puede verse asimismo el Villete del Cardenal Alveroni al Principe de Chélamar, que venía junto con una de sus Cartas à este Embajador de I4 de Diziembre de I7I8.

203 Cartas escritas al de Sicilia, Balsain, 30 de mayo de I7I8, AHN, Estado, 2884/2.

204 «Cartas de la correspondencia reservada del mariscal de Campo D. Blas de Loya con el cardenal Alberoni e instrucciones dadas a aquel general por el Ministro de la Guerra, D. Miguel Fernández Durán. Se recogieron de la viuda de este oficial general por medio de D. Juan Idiaquez, Conde de Salazar. Años de I7ı8 y I7I9", en ibídem, 2884/I.

205 En ibídem, 2884/ y 2884/2, pueden verse asimismo numerosos ejemplos de esa correspondencia oficial entre el Secretario del Despacho de Guerra, Miguel Fernández Durán y Blas de Loya, durante los años I7ı8 y I7I9.

$206 \mathrm{Al}$ respecto, cartas de los meses de febrero y marzo de I7ı,, por las que se informa a Alberoni del estado de las fortificaciones y de la llegada de los franceses a Fuenterrabía y de la toma de Vera, en AHN, Estado, $2884 /$ I.

207 El II de abril de I7I9 se informa a Alberoni de la prisión del coronel Jacomo Boissimene y hasta en dos ocasiones aprueba lo actuado indicando que debe ponérsele bajo la custodia del Intendente de Burgos, indicando que “D. Miguel Fernández Durán dirá a V.S. lo demás que se ofrece en orden a sus representaciones, por haberle yo mandado lo conveniente". Boissime será después uno de los testigos señalados en I720 para ser interrogados en la causa que se estaba formando contra Alberoni, AHN, Estado, 2884/I.

208 En otoño de I7ı9 se estudiaba el envío de una escuadra con destino a Bretaña. Entre la documentación de Alberoni se conserva un Dictamen, fechado el 26 de octubre y sin firma, en el que se valora la oportunidad de enviar la escuadra sin nuevas órdenes del Rey. Unos días antes, Alberoni trasladaba a Loya las instrucciones sobre cómo proceder. El I5 de octubre, Loya participaba a Alberoni la llegada de la escuadra a Santander y su partida hacia Bretaña, AHN, Estado, 2884/2. 
madurándose desde tiempo atrás. Concluida la guerra, habiéndose suprimido paulatinamente los puertos secos existentes en la Corona de Aragón, comenzó a pensarse en la posibilidad de trasladar asimismo las aduanas existentes en Navarra y las Vascongadas hasta los límites de la costa. El argumento, que parecía incontestable, venía a ser que de este modo los géneros podrían circular sin restricción alguna por el interior de las provincias, favoreciéndose las transacciones comerciales y contribuyendo además a controlar de manera más eficaz el contrabando de mercancías que se introducían desde el exterior por la $\operatorname{costa}^{209}$. La posibilidad de proceder al traslado de las aduanas interiores se había confiado al Reino de Navarra un año antes, estimándose por los consultores de Cortes que del mismo resultaría un claro perjuicio para la Real Hacienda, al tiempo que incentivaría el contrabando, esto es, exactamente el efecto contrario del que decía buscarse con la reforma ${ }^{210}$. Pero donde se suscitaron conflictos de gravedad fue en la provincia de Vizcaya. Sobre este particular, junto a las numerosas cartas de oficio del Secretario del Despacho de Guerra, Marqués de Tolosa, dirigidas a don Blas de Loya, «desde el 29 de julio de 1718, que sali de Madrid, para mandar las tropas que debian entrar en Vizcaya con motivo de sus inquietudes y mis respuestas hasta fin de enero de 1719, que tuve orden de pasar a la provincia de Guipuzcoa» ${ }^{211}$, que se conservan entre los papeles de Alberoni, pueden verse también las comunicaciones que este último dirigía a Loya y que permiten conocer su preocupación e implicación en el negocio:

«He mandado a D. Miguel Durán en nombre de S.M. -decía Alberoni el 22 de octubre de $1718^{212}-$ despache inmediatamente extraordinario a V.S. para prevenirle que habiendo resuelto el Rey entre las tropas en Vizcaya, se disponga V.S. luego a esta función, dando las providencias que sean más convenientes para el mejor logro del encargo y como en orden a este punto $y$ a lo demás que se ofrece he dicho al referido don Miguel lo que debe prevenir a V.I., me remito consecuentemente a cuanto le comunicare, confiando por fin de la buena conducta de V.I. el más cabal desempeño»

Blas de Loya habría solicitado inmediatamente mayores precisiones «sobre el modo de gobernarme en entrando en el Señorio y cuál es la mente del rey para mi mejor resumen, así en el trato con los de Bilbao como con los demás si acaso recibieren las tropas del rey sin oposición $y$ las máximas que deberé practicar según lo que sea del agrado de S.M. se ejecute para en adelante» ${ }^{213}$. El objeto de su intervención era hacer frente a los levantamientos registrados en la provincia de Vizcaya con motivo del traslado de las aduanas desde sus tradicionales ubicaciones hasta las fronteras. La decisión, que se había adoptado en agosto de I7I7, provocó una sería oposición en las provincias vascongadas, impidiéndose de hecho, en Vizcaya, su puesta en ejecución. El argumento principal de los agitadores era el agravio causado a las provincias exentas, a las que pretendía gravarse con contribuciones de derechos que vulneraban sus fueros y privilegios. El i6 de octubre de I7I8, Alberoni se dirigió solemnemente a las autoridades de la provincia de Guipúzcoa, lamentando las noticias recibidas acerca de tumultos y revueltas registrados en la misma motivados por el

209 Detrás de la medida pesaría la posibilidad de rentabilizar una renta no enajenada y ciertamente productiva. A. ANGULO, Las puertas de la vida y la muerte: la Administración aduanera en las Provincias Vascas (I690-I780), Bilbao, I995, explica que, a pesar de los esfuerzos realizados por Orry, no había podido modificar los aranceles de esta renta enajenada por la Corona hasta I7I4.

2IO El análisis de la limitada intervención de las Cortes, en S. SOLBES FERRI, "El intento borbónico de creación de un mercado interior unificado: el caso de Navarra (I7I8-I722)”, en M. LOBO y V. SUÁREZ (edits.), El comercio en el Antiguo Régimen, III Reunión Científica de la Asociación Española de Historia Moderna, 2 vols, Las Palmas de Gran Canaria, I994, II, págs. 277-289.

2II AHN, Estado, 2884/2.

2I2 Ibídem, 2884/I.

213 Ibídem, Copia de la respuesta que se dio al Cardenal, Miranda de Ebro, 25 de octubre de I7I8. Inmediatamente se le informaba de que se habían puesto a su disposición tres batallones de Infantería, cuatrocientos guardias de a pie y el regimiento de la Reina, reiterándole la orden de entrar en el Señorío de Vizcaya, Ibídem, San Lorenzo, 26 de octubre de I7ı8. 
rechazo a las Aduanas y advirtiendo que no cabía vuelta atrás en la decisión de mantener las aduanas en los parajes en los que habían sido establecidas ${ }^{214}$, toda vez que cualquier decisión en contrario sería opuesta a la razón y resultaría ofensiva al decoro y la autoridad real $^{215}$. Pocos meses después, sin embargo, el Rey admitía que no habiéndose conseguido aún controlar la situación en Vizcaya, no volviesen a instalarse los puestos hasta en tanto estuvieren suficientemente fortificados ${ }^{216}$. La oposición a la reforma de las Aduanas prosiguió, de suerte que, de nuevo en I722, el Rey se veía en la precisión de recordar que en modo alguno se había pretendido «minorar sus Fueros a quienes con tanta fidelidad me han servido siempre» ${ }^{217}$.

Alberoni intervino en otros muchos asuntos correspondientes también a la Secretaría del Despacho de Hacienda, Justicia y Gobierno Político, cuyo titular era José Rodrigo Villalpando. Fue Alberoni quien condujo las negociaciones que culminaron con la firma del Concordato de I7I7 y fue también Alberoni el motor de la ruptura posterior con Roma, a raíz de ser rechazada la propuesta de que se le otorgasen las bulas del arzobispado de Sevilla. Alberoni controló en estos años la correspondencia con los agentes en Roma, hizo y deshizo, sin que la presencia de Rodrigo pareciera estorbar en modo alguno sus múltiples manejos ${ }^{218}$. Fue Alberoni asimismo quien, con el concurso de José Patiño, dio nuevo impulso a las Intendencias, o sirviéndose de Riperdá desarrolló un ambicioso plan de relanzamiento industrial. En el Archivo Histórico Nacional se conservan documentos firmados por Alberoni dirigidos al Tesorero Goyeneche, disponiendo el libramiento a

2 I4 «Ha querido S.M. que Yo manifieste a V.S. de su Real ánimo y que les asegure que la nueva plantta de Aduanas no tiene, ni ha tenido en fin de perjudicar a los privilegios y fueros de la Provincia, ni agraviar en la mas mínima circusntancia a los Naturales del Pays, siendo esta providencia vnicamente para arreglar al Comercio con los Extrangeros y con lo Ynterior de este continente. Por lo demás los Naturales de essa Prouincia, deven quedar libres de todo Derecho de Aduanas y consequenttemente libres y francos todos los viueres y generos necesarios para el propio vso, y consumo; ni nunca ha sido diferente la Rl mente de S.M. ni opuesto a esta regla y disposicion el Ministerio», en BNM, mss. I2.879, ff. I37r-I38r.

2I5 AHN, Estado, 2884/I, El Cardenal Alberoni a la Provincia de Guipuzcoa, I6 de octubre de I7I8.

2I6 La sorpresa resultó mayúscula cuando se conoció que Blas de Loya, enviado a Vizcaya para reprimir la revuelta, había resuelto trasladar de nuevo los puestos aduaneros a sus anteriores ubicaciones, publicando un bando a tal efecto en la provincia: «Habiendo enterado de la carta de V.S. de 27 del antecedente — dirá Alberoni el 5 de diciembre de I7I8- y de su representación, de que me ha dado cuenta D. Miguel Duran, sobre diferir la ejecución de cuanto se le había mandado, debo decirle que el fin y deseo del es de poner en respeto sus órdenes y resoluciones; satisfacer a la Justicia y no dar lugar a que otra vez se cometan las maldades que en esas partes se han ejecutado. Para salvar el decoro Real, se había determinado el volver a poner los Ministros en los Parajes de donde los arrojaron y si ahora de pronto V.S. discurre que no conviene hacerlo, lo podrá dilatar algunos días, pero advierta V.S. que esta diligencia es la principal, y más importante de su comisión y que indispensablemente se debe ejecutar, y no puedo dejar de decir a V.S. que al le hizo bastante armonía el Bando que mandó promulgar para volver las Aduanas adonde estaban por lo pasado, porque además de ser esta una gran flaqueza y el punto esencial de la questión, debía V.S. haberlo preguntado antes de dar semejante paso. Lo que importa es abreviar cuanto pueda esas dependencias y todo lo demás que ocurre he mandado a D. Miguel Durán lo comunique a V.S.».

2I7 Cit. por C. de CASTRO, A la sombra de Felipe V, cit., págs. 342-343. Interpreta esta profesora que fueron el y Alberoni quienes se convencieron de que no era prudente insistir, comunicando a Loya la orden de no imponer nada por la fuerza.

2I8 Pueden verse al respecto la correspondencia con el cardenal Acquaviva, en AHN, Estado, 2884/I. En el mismo legajo se encuentra también la renuncia del cardenal Alberoni al obispado de Málaga, el 7 de enero de I7I8, en el tiempo en el que aspira al arzobispado de Sevilla. Sobre el conflicto generado posteriormente con este motivo, BN, mss. II.26I/29, Parecer de varios teólogos y canonistas que en I7I8 les hizo el sobre gobernarse en España con la mayor independencia del Papa, en satisfacción de las quejas que entonces se ofrecieron, especialmente por haber negado las bulas del Arzobispado de Sevilla al Cardenal Alberoni y en AHN, Estado, 4830, Dictamen sobre si el cardenal Alberoni había de gozar las rentas de la mitra de Tarragona, como administrador ecónomo de ellas o como usufructuario, por alimentos de su persona, 24 de agosto de I7I 8 y en ibídem, 2884/2, Copia de la consulta del Consejo de Castilla de 26 de abril de I7ı, con motivo de retardarse la expedición de las Bulas del Arzobispado de Sevilla a favor del cardenal Alberoni y un documento, sin fecha, titulado Valores del Arzobispado de Sevilla. Sobre el papel de Alberoni en la conclusión del Concordato, A. MESTRE SANCHÍS, "La Iglesia y el Estado", cit., pp. 277-333, que presta atención particular a la situación de ruptura con Roma en I709 y a la reconducción de las negociaciones a partir de la entrada en escena de Alberoni y la conclusión del Concordato en I7I7. 
diferentes personas de cantidades relacionadas con trabajos realizados para la puesta en funcionamiento de la fábrica de paños de Guadalajara. Como ocurre en relación a otros tantos asuntos, puede observarse asimismo la intervención, en idénticos términos del Marqués de Tolosa y no de Rodrigo, titular del Departamento de Hacienda ${ }^{219}$. Algo parecido puede señalarse en relación a la política indiana, en particular al desarrollo comercial. La extinción de la Secretaría del Despacho de Indias en abril de I7I5 habría dado paso a una división material de competencias en relación a los territorios ultramarinos entre los tres Departamentos ministeriales subsistentes a partir de abril de I7I7. A su vez, el mecanismo de la reserva habría favorecido la directa intervención de Alberoni, al que vemos despachar las noticias relativas a la expedición dirigida a Pensacola, remitir instrucciones al comisario de Marina, José del Campillo, para su paso a Veracruz, o recibir las cartas remitidas al monarca por el Virrey Marqués de Valero ${ }^{220}$. Junto a Alberoni interviene habitualmente Miguel Fernández Durán, quien desde I7i8 aparecía como responsable de un Departamento de Guerra y Marina al que se habrían sumado también los asuntos ultramarinos, a excepción de los de naturaleza eclesiástica, que conservaría, unidos a los de la Península, el Marqués de la Compuesta. El establecimiento del nuevo gran Departamento de Guerra, Marina e Indias parece claro a la luz de varias noticias. Por una parte, así se desprende de una relación de las reformas orgánicas experimentadas por la Secretaría del Despacho de Guerra a lo largo del siglo XVIII, en la que, tras dar noticia de la distribución de los asuntos de Indias en I7I5 entre las restantes Secretarías de Guerra, Justicia y Hacienda, se añade que se habría «declarado después en el año 1718 que estos [los negocios relativos a la América española], excepto lo eclesiástico, debían correr por la misma Secretaría de Guerra» ${ }^{221}$. En el mismo sentido, la noticia ofrecida por PRADO Y ROZAS ${ }^{222}$, según el cual «el año de 1718 mandó S.M. que todas las dependencias de Indias corriesen por la Secretaría de Guerra y Marina, excepto lo Eclesiástico, que debía continuar (como hasta entonces por la Secretaría de Justicia) ». Asimismo, una relación anónima formada años más tarde, declara que «en el año de 1721 se hizo la última separación de las Secretarías de Indias, Y Marina que estaban unidas à la de Guerra, quedándose la de Gracia y Justicia en la posesión de que por ella se despachasen las provisiones eclesiásticas de Indias, como se mandó en el año de $1718{ }^{223}$. Por otra parte, cuando en noviembre de I7I9 el Rey hizo merced a Fernández Durán de título de Castilla como Marqués de Tolosa, el mismo era mencionado como Secretario de Estado y del Despacho Universal de la Guerra, Marina e Indias ${ }^{224}$. Apenas un mes más tarde, el Marqués de Tolosa habría logrado reunir bajo su dirección la totalidad de los asuntos indianos. Así, en un aviso remitido por este Ministro a Grimaldo el 7 de diciembre, le participa habérsele encomendado por el Rey todas las dependencias de Indias, tanto eclesiásticas — que aún no estaban a su cargo- como las de Justicia, Hacienda, Marina,

2I9 AHN, Estado, 2884/3. Sobre la política de creación de fábricas, resultan imprescindibles los estudios de A. GONZÁLEZ ENCISO, "La industria en el Reinado de Felipe V", en E. SERRANO, Felipe V y su tiempo, cit., págs. 49-76; Estado e Industria en el siglo XVIII: la fábrica de Guadalajara, Madrid, i980.. Para el papel de Patiño en relación a la formación de la Ordenanza de intendentes y acerca de otras tantas de las reformas proyectadas en este tiempo, el recientemente publicado por C. PÉREZ FERNÁNDEZ TURÉGANO, Patiño y las reformas de la Administración en el Reinado de Felipe V, Madrid, 2006.

220 AHN, Estado, 2884/2.

22I En una nota marginal se indica además «que estuvieron unidas hasta enero de I72I, que se separaron», AGS, Guerra Moderna, 730I, Plantas de la Secretaría del Despacho de la Guerra y providencias generales para todas, desde el año de I7I4 en que se las dio su primer establecimiento. Citando este documento, G.BERNARD, Le Secrétariat d'État et le Conseil Espagnol des Indes, cit., pág. 33, quien afirma que «pour décharger Rodrigo, tuot ce qui avait rapport à la Marine et aux Indes passa sous a dépendance du secrétaire d'État a la Guerra».

222 A. PRADO Y ROZAS, Reglas para oficiales de Secretarías y catálogo de los Secretarios del Despacho y del Consejo de Estado que ha habido desde los Señores Católicos hasta el presente, junto con las plantas dadas a las Secretarías, Madrid, I755, p. I26.

223 AHN, Estado, 3439, exp. 34. Igualmente PRADO Y ROZAS se refiere a la división, en I72I, de la Secretaría servida por Fernández Durán, en dos departamentos, uno de Guerra, a cuyo frente se sitúa Patiño y otro de Marina e Indias, «que estaban unidas a la de Guerra», cuyo titular será Andrés de Pez, Reglas para Oficiales, p. I27.

224 Gaceta de Madrid, núm. 48 (I7I9), del martes 28 de noviembre. 
etc. ${ }^{225}$. Probablemente el incremento de sus competencias, en detrimento de las que formalmente tenía asignadas aún el Marqués de la Compuesta, tuvo lugar en ese mismo momento, coincidiendo, pues, con la salida de escena de Alberoni y con la reorganización del despacho acometida en el día siguiente a la caída en desgracia de quien en los últimos dos años había acaparado el despacho con el monarca ${ }^{226}$.

225 «Habiendo resuelto S.M. y dádome orden para que las dependencias de Indias, así Eclesiásticas como de Justicia, Hacienda, Marina y todas las demás de aquellos Reinos corran por la oficina de mi cargo, lo participo á V.S. de su Real orden, para su inteligencia. Dios guarde a V.S. muchos años. Palacio, 7 de diciembre de I7I9», AHN, Estado, 3497.

226 Una disposición de 6 de diciembre de i7ı9 venía a señalar así los días de la semana en que cada uno de los tres Ministros — Grimaldo, Fernández Durán y Rodrigo- debían despachar con el monarca, ibídem, 3439, exp. 9 . 